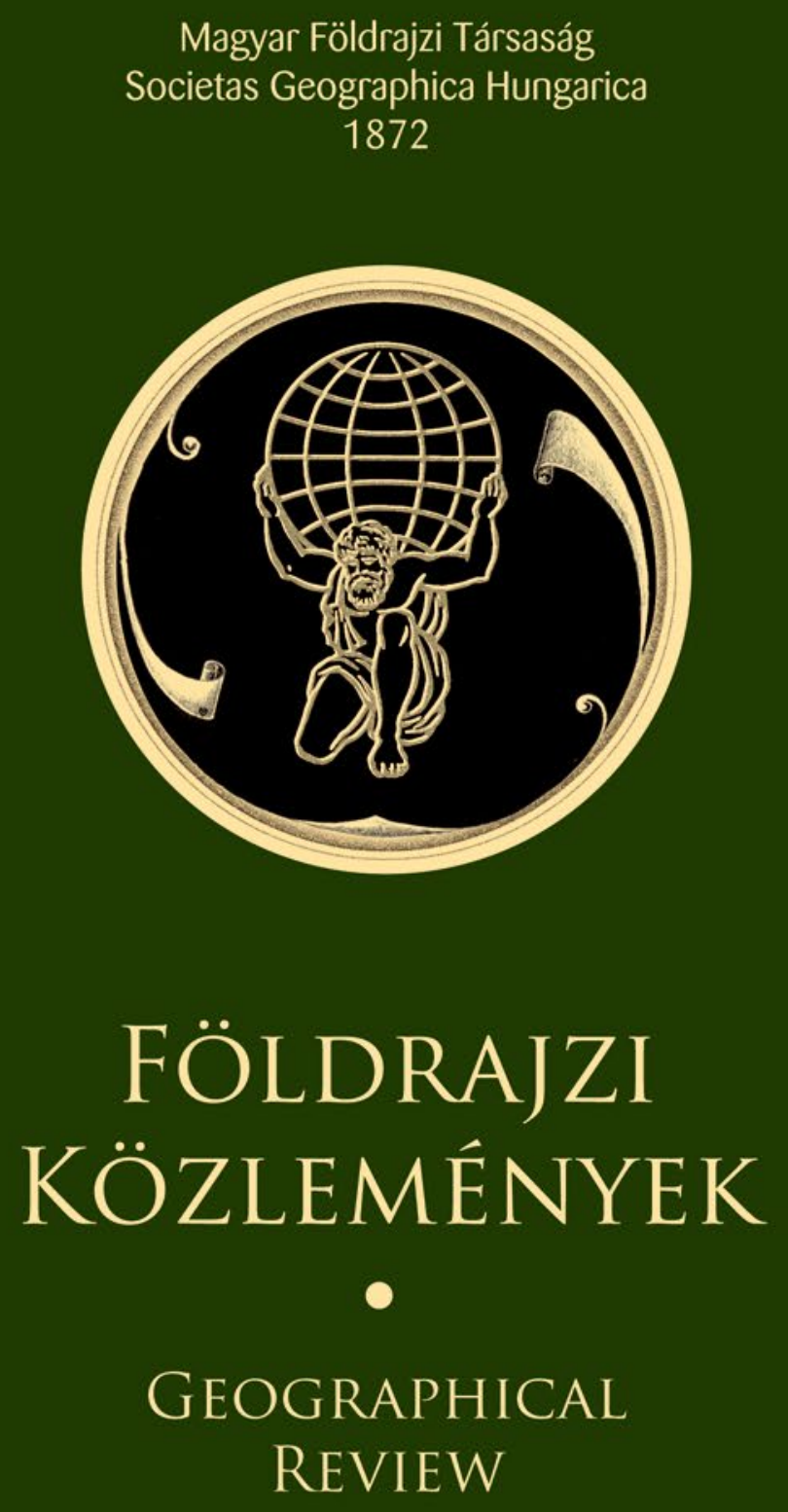

145. évfolyam, 3. szám 2021 


\section{FÖLDRAJZI KÖZLEMÉNYEK}

\section{A Magyar Földrajzi Társaság tudományos folyóirata}

Geographical Review $•$ Geographische Mitteilungen

Bulletin Géographique • Bollettino Geografico • Географические Сообщения

Főszerkesztő / Editor-in-Chief

JENEY LÁSZLÓ

Főszerkesztő helyettesek / Deputy Editors-in-Chief

EGEDY TAMÁs (felelős szerkesztő / Managing editor), BotTLIK ZsoLT

Szerkesztők / Editors

HoRvÁTH GERGELY, PAPP SÁNDOR

CSAPÓ JÁNOS (külkapcsolati menedzser / Manager for internationalisation)

Szerkesztőbizottság / Editorial Board

Veit Bachmann (DE), Benedek József (RO), Dombay István (RO), Fábián Szabolcs, Fodor Gyula (UA), GyóRi Róbert, Ionel Haidu (FR), Illés SÁndor, Steven Jobbitt (CA),

Kozma Gábor, Lóczy Dénes, Peter Lugosi (UK), Mészáros Minucsér (RS), Mucsi LásZló, SZABó GYörgy, TimCSÁK GÉZA (SK), Tímár Judit, Ladislav TolmáČ (SK),

THOMAS M. WILSON (US, IE)

Tudományos Tanácsadó Testület / Scientific Advisory Board

Alexandr Artemyev (KZ), Mariusz Barczak (PL), Barta Györgyi,

Beluszky PÁl, JÜrgen Breuste (AT), Bujdosó Zoltán,

Centeri Csaba, Csorba Péter, Dövényi Zoltán, Frisnyák SÁndor,

GraŻyna FurgaŁa-Selezniow (PL), Gábris Gyula, Gál Zoltán,

György Ottilia (RO), Hufnágel Levente, Dorina Camelia Ilieş (RO),

Kerényi AtTila, Blaž Komac (SI), JoAnna KosmaczewsKa (PL),

Kovács Katalin, Kocsis Károly, Kovács Zoltán, Mari LásZló, MeZŐsI Gábor,

Michalkó Gábor, Ladislav Mura (SK), Pajtókné Tari Ilona, Pap Norbert,

Papp-Váry Árpád, Maria Paradiso (IT), Penksza Károly,

Szilárd Lehel Poszet (RO), Probáld Ferenc, Anton Van Rompaey (BE),

Mihaela Sima (RO), Parikshat Singh Manhas (IN),

SZabó József, SZabó Szilárd, SzIlassi Péter, Tóth GéZa, Tardy János, VARAJTI Károly, Marek WięCKOWSKi (PL)

A Földrajzi Közleményeket az alábbi adatbázisok indexelik:

Földrajzi Közlemények is abstracted/indexed in: EBSCO Information Services, Ulrich's Periodicals Directory, Index Copernicus International, Crossref.

Szerkesztôség: 1112 Budapest, Budaörsi út 45. Telefon, fax: (06-1) 309-2683

E-mail: kozlemenyek@foldrajzitarsasag.hu. Honlap: www.foldrajzitarsasag.hu

Az MTA X. Földtudományok Osztályán kiemelt státuszba sorolt folyóirat. 


\title{
AZ ORSZÁGOS TÁJKARAKTER-ELEMZÉS KEZDETEI MAGYARORSZÁGON
}

\author{
KONKOLY-GYURÓ ÉVA - VASZÓCSIK VILJA - CSORBA PÉTER \\ - SCHNELLER KRISZTIÁN - JOMBACH SÁNDOR \\ - BOROMISSZA ZSOMBOR - ERDEI TÍMEA - KESZTHELYI ÁKOS - BALÁZS PÁL \\ - KISS DÁNIEL - TELEKI MÓNIKA - BÁNHIDAI ANDRÁS - CSÓSZI MÓNIKA \\ THE BEGINNING OF THE NATION- \\ WIDE LANDSCAPE CHARACTER ASSESSMENT IN HUNGARY
}

\begin{abstract}
Landscape character assessment is built on the Landscape Convention of the Council of Europe, which considers landscape as an area perceived by man, formed by the interactions of man and nature. According to the exemplary British practice of landscape character assessment, the particular combination and the unique composition of landscape elements have to be taken into account rather than the specific features independently. Its primary concern is that the whole is more than the sum of the parts. Landscape character assessment results in the identification of landscape character types and landscape character areas. Identifying the character types and character areas happens at more hierarchy level (national, regional, micro-regional and local level). Defining the boundaries, the characteristics, and the main factors contributing to the formation of the character should be a value-free description of the given state. The following stage of the assessment is the landscape evaluation. Making a judgement on the actual state involves locals in a participatory process, and it is the preparatory phase of formulating the landscape quality objectives.

In Hungary, the first landscape character assessment, covering the entire area of the country, was carried out between 2017 and 2021. Four micro-regional case studies complemented the nationwide research. The present paper gives a brief overview of the methods used at the national level, including the feedback from the micro-regional assessment, and summarises the results.
\end{abstract}

Keywords: landscape character assessment, landscape research, landscape perception, Hungarian landscapes, Landscape Convention of the Council of Europe

\section{Bevezetés}

A tájak karakter alapú számbavételének gyökerei az 1990-es évekig nyúlnak vissza, amikor megkezdődött az az Angliára és Skóciára kiterjedô tájelemzés, amely Nagy-Britannia tájkarakter-területeinek meghatározását túzte ki célul (Countryside Commission 1987, Countryside Agency 1999, Natural England 2014). Mindeközben a Firenzében 2000-ben elfogadott Európai Táj Egyezmény - 2021-től új hivatalos néven: Az Európa Tanács Táj Egyezménye - a táj fogalmának meghatározása révén tette központi fogalommá a tájkaraktert, ami szerint „táj az emberek által érzékelt terület, amelynek jellege természeti, illetve antropogén hatások és kölcsönhatások révén alakul ki”. A jelleg, azaz a karakter jelentősége abban áll, hogy nem a tájalkotók különböző jellemzőire koncentrál, hanem ezek együttesére, kapcsolatára, a táj mintázatára, kompozíciójára. Alapelve, hogy az egész nem ragadható meg a részek összegeként, hanem a kompozíció által új minőség jön létre, ami a sajátos, egyedi és észlelhetố megjelenésben mutatkozik meg. Amint a brit tájkarakter-elemzési útmutató nyomán megfogalmazhatjuk, ,a tájkarakter a természeti és az antropogén tájalkotó elemek elkülöníthetó, felismerhetó, konzisztens rendszeréböl, sajátos együtteseiból kialakult jellemzók összessége, amely a tájakat egyedivé, megkülönböztethetôvé teszi" (SwAnwick, C. et al. 2002; KonKOLY-GyuRó É. 2013). Az elemzésnek az a célja, hogy az egyediséget, a sajátosságot, a szomszédos tájak között mutatkozó lényeges, 
észlelhető különbséget feltárja, ami a tájformáló tényezők és a tájalkotó elemek sajátos kombinációiban, együtteseiben nyilvánul meg. A tájkarakter fontos része az emberek identitásának és tájhoz való kötődésének is, hiszen a természet és az ember kölcsönhatása alakítja ki. Meghatározásának szemléleti alapja, hogy a tartalom és a forma, azaz a materiálisan jelen lévő tájalkotók és megjelenésük, a tájkép (látvány) és más érzékelhetô tulajdonságaik (hangok, illatok) egyaránt szerepet játszanak benne (KONKOLY-GYURó É. et al 2010).

A Táj Egyezmény az aláíró országok kötelezettségévé teszi a tájak számbavételét és értékelését az országok teljes területét lefedően, azaz a települési és ezeken kívüli térségekre vonatkozóan is. A fentebb idézett tájmeghatározás alapján ez a számbavétel a karakter alapján történő tájlehatárolást és a tájjellemzők bemutatását jelenti. E kötelezettség és a brit példa nyomán Európa számos országában születtek tájkarakter-elemzések, amelyekről több összefoglaló tanulmány született. Elsőként a European Landscape Character Assessment Initiative (ELCAI) projektben megjelent kiadvány (WASCHER, D. M. 2005) tudósított átfogóan a táj(karakter)-vizsgálatokról számos európai példa áttekintése nyomán, majd könyveket, illetve fejezeteket szenteltek a módszertan bemutatásának (ANTROP, M.-VAN EetVelde, V. 2017; FAirClough, G. et al. 2018), nem utolsósorban pedig több tudományos írás is adott összefoglaló áttekintést a tájkarakter számbavételének számos példájáról (RAYMOND, R. et al 2015; SiMENSEN, T. et al. 2018).

Ezen előzmények után indult meg hazai tájaink karakter alapú azonosításának és leírásának folyamata a 2016-2021 között zajlott tájkarakter-kutatás keretében, amely az egyik fejlesztési eleme volt az Agrárminisztérium által koordinált „Közösségi jelentőségű természeti értékek hosszú távú megórzését és fejlesztését, valamint az EU Biológiai Sokféleség Stratégia 2020 célkitűzéseinek hazai megvalósítását megalapozó stratégiai vizsgálatok" címú KEHOP 4.3.0-VEKOP-15-2016-00001 azonosítószámú projektnek.

Az ötéves időtartamú országos tájkarakter-kutatás céljai a következőkben foglalhatók össze:

- az Európa Tanács hazánk által is ratifikált Táj Egyezménye végrehajtásából fakadó feladatok teljesítése;

- a hazai tájak változásának hosszú távú, országos léptékú nyomon követéséhez szükséges egységes módszertani keretek megteremtése;

- a Természetvédelmi törvény 7. §-a szerinti tájjelleg-védelem szakmai megalapozása;

- a tájkarakter-alapú döntéshozatal alkalmazásának, valamint a tájkarakter-védelem kulcságazatokban, hatósági/bírósági eljárásokban történő érvényesítésének és gyakorlati alkalmazásának megalapozása;

- a biológiai sokféleség megőrzésének 2015-2020 közötti időszakra szóló nemzeti stratégiájának 5. célkitűzésében a táji sokféleség és az ökológiai tájpotenciál megörzésére vonatkozóan megfogalmazott feladatok végrehajtása;

- a tájjelleg megórzendő és rehabilitálandó elemeiről a terület-és településrendezés, valamint a táji és a településképi arculati kézikönyvek számára információ szolgáltatása;

- a térségi területfejlesztési és ágazati stratégiák számára a fenntartható fejlödési célok megfogalmazásának megalapozása;

- a tájváltozást eredményező tevékenységek támogatási rendszerei számára tájkarakter-védelmi célú értékelési szempontok megfogalmazása.

Írásunkban vázlatos áttekintést adunk a hazai tájkarakter-elemzésnek a fenti kutatás keretében kidolgozott módszertanáról és eddig elért eredményeinek egyes részleteirôl, amelyek fontos lépést jelentettek a kitűzött nagy ívű célok elérésének irányába. Fontos szem előtt tartani, hogy nem egy lezárt folyamatról van szó, erre utal a tanulmány címe is. A tájkarakter-elemzésnek ugyanis alapvető része az érzékelt, észlelt, közvetlenül megtapasztalt (percepcionális) információk vizsgálatba vonása, amit az ország egész területére nem tudtunk elvégezni a projekt keretein belül. 


\section{Anyag és módszer}

Az egész ország területére kiterjedő tájkarakter-kutatás során térinformatikai eszközökkel pusztán irányadó (indikatív) lehatárolást végeztünk, hiszen az ország egészére kiterjedô terepi felvételezés hiányában nem volt módunk a digitális térképelemzés eredményének egyértelmú igazolására (validálására). Azonban négy mintaterületen (Sopron-Fertő, Gerecse, Tápióság, Tiszazug) részletes kistáj szintú és helyi (települési) részletességú percepcionális elemzés is történt. A mintaterületek kiválasztásánál törekedtünk arra, hogy számos eltérő karakterű, az országot megfelelően reprezentáló térséget bevonjunk a részletes vizsgálat körébe.

A szemléleti és módszertani alapelveket és a kikristályosodott fogalomrendszert a bevezetôben említett áttekintő írásokra, az Európai Táj Egyezményre és a hazai tájkarakterre vonatkozó szakirodalomra (CSEMEZ A. 1996; KONKOLY-GYURó É. et al. 2010; KONKOLYGYURÓ É. 2013) támaszkodva, valamint a kutatási projekt keretében tájépítész, geográfus, építész, agrár- és környezetmérnök szakértők részvételével folyt egyeztetések eredményeként konszenzussal alakítottuk ki

\section{Szemléleti és módszertani alapelvek}

A tájkarakter-elemzés az alábbi alapelveken nyugszik:

- a táj kontinuum, a települések is részei, a tájak az ország egész területét lefedik;

- tájkaraktertípusok és tájkarakter-területek azonosítását végezzük el több léptékben, amelynek eredményeként hierarchikus rendszer jön létre;

- mennyiségi és minőségi jellemzőket is vizsgálatba vonunk az elemzés során;

- a tájkarakter jellemzőinek azonosítása értéksemleges, szintetizált információt ad a tájalkotó elemek együtteseiról és a tájformáló tényezőkről, míg a táj értékelése az elemzés második fázisában történik meg;

- a tájkarakter-elemzés során nem a részek, hanem adott jellegzetes tájelemegyüttesek, mintázatuk, kompozícióik és a kölcsönhatásaik jelentik a lényeget, amelynek során az egyediség, sajátos jelleg meghatározása kerül előtérbe.

\section{Alapfogalmak}

Tájformáló tényezók: mindazon természeti és emberi hatótényezők, amelyek eredménye a tájelemek (alapkőzet, talaj, éghajlat, levegó, víz, élővilág, tájhasználat, társadalmi környezet) létrehozása és alakítása által érzékelhető és mérhető materiális formában is megjelenik a tájban.

Tájelemek: adott tájként lehatárolt térségben materiálisan és érzékelhetően is megjelenő felszínalaktani képződmények és a felszínen előforduló egyedi, homogén természeti vagy antropogén tájalkotók. Lehetnek:

- felszínalaktani képzódmények, pl. hegy, kúp, gerinc, völgy, medence, domb, hullámos sík, tagolatlan sík;

- felszínen elooforduló tájelemek, pl. víz (tó, patak, csatorna, egységes folyószakasz), növényzet (fa, fasor, erdőfolt, homogén erdőtömb, gyepfolt, szántó-, szőlőtábla, gyepfolt, kert), építmény (egyedi épített objektum) vagy kopár felszín (homokdűne, sziklakibúvás).

Kiterjedésüket tekintve lehetnek:

- pontszerú elemek, egyedi objektumok, pl. magányos (szoliter) fa, forrás, kilátó;

- területi elemek, homogén élóhelyek, ökotópok; 
- vonalas elemek, pl. utak, vízfolyások, de ez utóbbi típusba tartoznak a szegélyek átmeneti élőhelyei, az ökotonok is.

Tájmozaikegység (a tájat egy sajátos mintázatú mozaiknak tekintő tájökológiai elmélet [FORMAN, R. T. T. 1995] alapján): élőhelyek, illetve tájelemek együttese; viszonylag egynemú, vagy jellemzően együtt előforduló felszínborítás-típusok és a domborzat kombinációjából kialakuló múködési egység. Ilyen lehet pl. adott domborzattípusban előforduló összefüggő szántótáblák tömbje (egynemú szántó síkságon), erdőtömb (mozaikos erdő dombságon), vagy domborzattól függetlenül bárhol előforduló tájelemegyüttes (üdülőteleppel körülvett bányató, kertes, családi házas lakótömb, városias lakótömb, ipari vagy kereskedelmi településperem, változatos kertség, gyep-szántómozaik, vízfolyás és az azt kísérő parti sáv, vagy valamely út és az azt kísérő növényzeti sáv). A tájmozaikegységet alkotó tájelemek együttesei lehetnek területi, azaz foltszerű, valamint vonalas, azaz sávos kiterjedésúek.

Tájkaraktertípus: a tájmozaikegységek sajátos, ismétlődő mintázatából kialakuló, hasonló karaktervonásokat mutató téregység, amely az ország területén több helyen előfordul, de mindenütt ugyanazokat a főbb jellegzetességeket hordozza, függetlenül attól, hogy hol található. A tájkaraktertípusok a felszínborítás jellemzői alapján fótípusokba vonthatók össze, ugyanakkor a részletesebb, kistáj szintű és helyi elemzés során altípusokra oszthatók az egyes, terepi felmérés során azonosított, a karaktert adó vonások sajátos, ismétlōdő, előfordulása alapján. Pl. az Agrártáj főtípusban találjuk a Szántódomináns, homogén síksági táj típust, amin belül megkülönböztetjük a Szántódomináns, erdösávokkal tagolt, alacsony síksági táj majorokkal és kistelepülésekkel altípust.

Tájkarakter-terület: egyedi, helynévvel megnevezett terület, valamely tájkaraktertípus egyszeri, sajátos földrajzi elófordulása (pl. a Szólö-kert-településmozaikos hegységperem erdős hegytetôvel tájtípus területi előfordulása a Badacsony és a Tokaji-hegy), illetve a tájkaraktertípusok sajátos kombinációja által jön létre (pl. a Szántó-gyepmozaikos hullámos medencetáj, a Változatos felszínborítású hegységperem és a Települési táj dombságon és hegységperemen tájtípusok együttese Soproni-medence). A tájkarakter-területek a földrajzi tájak hierarchiáját és megnevezését követik, és azokat a lehatárolásuk is figyelembe veszi a tájkaraktertípusok mintázatával együtt.

\section{Módszer}

A tájkarakter-kutatást két területi szinten végeztük, országosan és kistáj szintű mintaterületeken. A tájkarakter-téregységek azonosításánál a tájformáló tényezők és a tájalkotó elemek között fennálló ok-okozati összefüggések alapján lényegében csak a tájalkotó elemek együtteseit kell vizsgálnunk, mert ezek a hatótényezók összességének a megnyilvánulásai, amelyek az általános és a sajátos, egyedi karakterisztikákat mutatják. Ezek közül kell meghatároznunk a kulcsjellemzőket, amelyek alapján egyik táj elkülöníthető a másiktól. Hatótényezők az éghajlat, a földtani felépítés, a talaj, a vízrajzés az emberi tevékenységek, továbbá a tájhasználatok, amelyek megnyilvánulása a domborzat és a felszínborítás mérhető és láthatóan is érzékelhető mivolta. Utóbbiak jellegzetességei, mennyiségi és minőségi tulajdonságai alapján azonosíthatók a tájkarakter-téregységek több hierarchiaszinten.

Az ország egészére ezért első megközelítésben térinformatikai elemzéssel a felszínborítást és a domborzati formákat jellemző, összetett (komplex) indikátorok alapján végeztük el a tájmozaikegységek, majd a tájkaraktertípusok lehatárolását. A típusok sajátos mintázata pedig az országos tájkarakter-területeket rajzolta ki, amelyek jelentős egybeesést mutattak a földrajzi tájakkal. Megállapítottuk, hogy nagytáj szinten, ami a valós országos léptéket jelenti, a tájkarakterről pusztán elnagyolt általánosságok mondhatók el, aminek mind a tervezési, mind a közigazgatási alkalmazhatósága erősen megkérdőjelezhető. Ezért az egye- 
di, névvel megnevezett tájkarakter-területek esetében a középtáj léptéket és részletességet tekintjük országosan lehatárolandó és leírandó tájkarakter-téregységeknek, mert ezen a szinten valóban jellegzetesen elkülönülő, specifikus tervezési irányelveket, szabályozást, védelmi és fejlesztési intézkedéseket igénylő tájak azonosíthatók. A vizsgálatunk léptéke ezért a földrajzi tájbeosztás szerinti középtáj szintre tevődött. A fentiekben felsorolt hatótényezőket, mint leíró indikátorokat vettük figyelembe a középtáj szintű tájkarakter-területek leírásához.

Az elemzés következő fázisában a mintaterületi elemzéseket végeztük el. Itt kistáji és helyi léptékben az észlelt minőségi jellemzők, azaz a percepcionális információ vizsgálatba vonását is elvégeztük. Ez az a többlet, amitől a tájvizsgálat érdemben tájkarakter-elemzéssé válik. A táj észlelésének eszköztárába tartozik a szakértői terepi felmérés és a helyiekkel folytatott párbeszéd. A kutatás során az irányadó országos lehatárolás és a helyszíni felmérések, valamint a tájról alkotott vélemények alapján kijelöltük a tájkarakter-altípusokat, az országosan nem azonosított tájmozaikegységeket és a kistáj szintű tájkarakter-területeket. Ezeket visszacsatoltuk az országos rendszerbe, ellenőriztük a tartalmi és a nevezéktani kapcsolódásokat, valamint a határmegvonást, így az elemzés egyre pontosabb megközelítésúvé vált a felülről lefelé és alulról felfelé építkezés elvét követve (1. ábra).

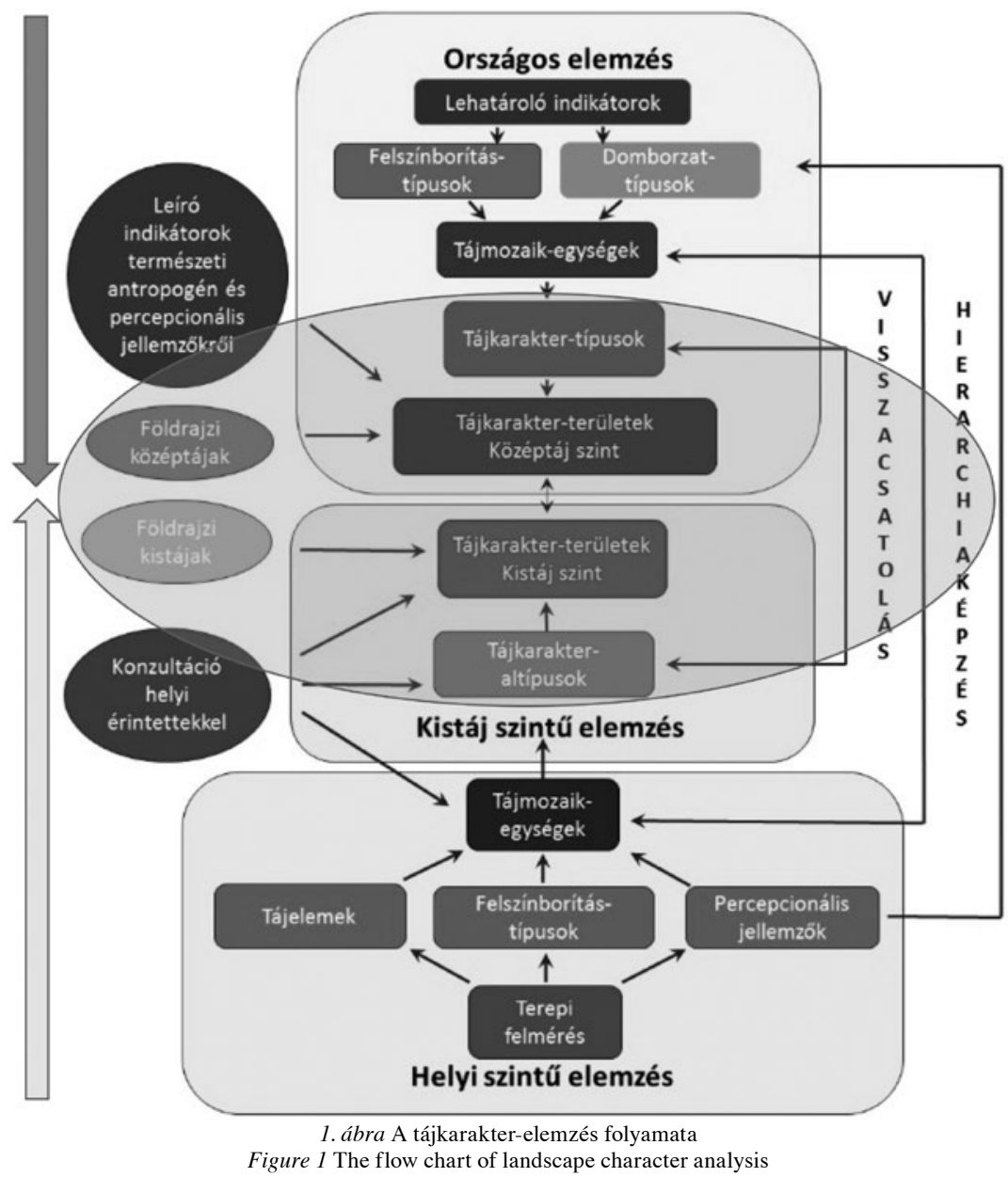


A mintaterületi eredményeket jelen írásban csak a tájkarakter-hierarchia megalkotása és az országos visszacsatolás témaköreit érintően mutatjuk be. A teljes körű ismertetést terjedelmi okokból egy következő írásban tervezzük megjelentetni. A módszertan részletes bemutatása pedig a Tájkarakter határozó címú dokumentumban (KONKOLY-GYURÓ É. 2021) elérhető.

\section{Eredmények}

Az országos lefedettségü, középtáj szintü elemzés eredménye

\section{A tájkaraktertípusok azonosítása}

Az ország egészére a tájkaraktertípusok középtáj szintú lehatárolásához a domborzat és a felszínborítás indikátorok összemetszésével azonosított tájmozaikegységeket használtuk fel, amelyek kódolása és megnevezése tartalmazza a felszínborításra és domborzatra vonatkozó információkat (pl. szántódomináns homogén síksági tájmozaikegység, vagy erdö-gyepdomináns középhegységi tájmozaikegység). Ezek kiterjedése, ismétlődő mintázata, egymáshoz viszonyított helyzete alapján országosan 50 tájkaraktertípust azonosítottunk, amelyeket az alábbi főtípusokba soroltuk (zárójelben a hozzájuk tartozó tájkaraktertípusok számával): Települési és ipartájak (10); Agrártájak (12); Erdös tájak (5); Vizi tájak (9); Változatos felszínborítású tájak (14) (2.ábra).

A tájkaraktertípusok lehatárolásának szempontjait az alábbiakban foglaljuk össze.

- A legkisebb tájtípusnak tekintett folt területét $4 \mathrm{~km}^{2}$-ben határoztuk meg. Itt a $2 \mathrm{~km}$-es távolságot vettük alapul, mint a látótérnek jól belátható elő- és középtér részét.

- A települések esetében megkülönböztettük az önmagukban $4 \mathrm{~km}^{2}$-t meghaladó kiterjedésű, jellemzően kompakt települési tájakat és az agglomerálódó települési tájakat, valamint a nagyvárosokat. A domborzattípusok szerinti elkülönítés mellett a vízfolyások és a tavak vízparti zónájában épült városokat és nagy kiterjedésú falvakat is önálló típusba soroltuk.

- A szántó, a gyep, illetve a szőlők és a kertségek dominanciája által jellemezhető agrártájak fótípuson belül elkülönítettük a homogén és a mozaikos felszíneket és a domborzati formákat.

- A vízfelszínek és a vízhatású területek tájkarakter-formáló szerepét hangsúlyoztuk a Vizi táj főtípus létrehozásával. Ott, ahol folyók és tavak vízfelszínének dominanciája, vagy jelentős előfordulása mutatkozott, ezeket önálló tájkaraktertípusba soroltuk, folyótáj és tavi táj megnevezéssel. Nem használtuk sem a folyó menti, sem a tóparti táj megnevezést, mert e kifejezések nem a vízfelszín jelenlétére, hanem a parti szárazföldre utalnak. A karakter szempontjából viszont épp a vízfelszín és a parti zóna együttese a mérvadó. A vízhatású területek a vízdomináns megnevezést kapják.

- Számos kettôs felszínborítás-dominanciájú tájmozaikegységből képeztünk tájkaraktertípust pl. Gyep-szántómozaikos vagy Kert-erdómozaikos megnevezéssel.

- Azokat a térségeket, ahol jellegzetes términtázatot alkotva három vagy több felszínborítás-típus jelenik meg ismétlődôen, a Változatos táj főtípusba soroltuk, pl. Település-kert-erdömozaikos hegységperemi táj stb.

- A felszínborítás gyakran több szomszédos domborzattípusban is folyamatos átmenetet képez, különösen a szántók a síkságokon és a csatlakozó dombságokon, illetve az erdők a hegységben és a hegységperemeken. Ezekben az esetekben a tájkaraktertípus lehatárolásakor összevontuk ezeket a területeket, pl. Szántódomináns, homogén hullámos síksági és dombsági táj vagy Erdődomináns, jellemzóen homogén középhegységi táj megnevezéssel. 
A tájkaraktertípusok kategorizálása alapos, átgondolt elemzés és számos szakértői egyeztetés nyomán született, ezért e kategóriákat véglegesnek tekintjük. A lehatárolást illetően azonban szükséges lehet a jövőbeni pontosítás a kistáj és a helyi szintű további elemzések visszacsatolását követően. Ezért a tájkaraktertípusok jelenlegi határvonalai - bár középtáj léptékben megfelelő pontosságúak - kistáj és helyi szinten egyaránt egyelőre csak irányadónak (indikatívnak) tekintendők.

\section{Az országos tájkarakter-területek azonosítása}

A tájkarakter-területek lehatárolása az ország egészére a földrajzi középtájak és a fentiekben ismertetett tájtípusok térképe alapján történt. Magyarország területén 60 tájkarakter-területet különítettünk el. Itt a földrajzi tájak mellett egyes esetekben figyelembe vettünk a néprajzi tájakat, ott, ahol egyes jellegzetességeik erőteljesen tájkarakter-meghatározók (pl. az Ốrség szeres településszerkezete). Önállónak tekintettük az agglomerálódó nagyvárosi térségeket is kiterjedésük és a beépített tér mintázata alapján.

Tekintettel arra, hogy a tájkarakter-területek határai a bennük előforduló tájkaraktertípusokhoz igazodnak, jelen lehatárolásuk a jövőben szintén pontosításra szorul a típusok kiigazításának korábbiakban ismertetett indokai alapján, így a tájkarakter-területek határait is egyelőre csak irányadónak (indikatívnak) tekintjük.

A tájkarakter-területek megnevezésénél, miként a lehatárolásukkor is, a földrajz középtáj szintű tájneveiből indultunk ki. Ezek többsége mind a tudományos tájfelosztásokban elfogadott (DÖVÉNYIZ. 2010; CsORBA P. 2018), mind a köztudatban meggyökeresedett, ismert tájnév. A nevezéktanban a földrajzi tulajdonneveket többségében megtartottuk. A hegységeknél a peremterületeket nem választottuk külön, ezért itt a hegyvidék, vagy a vidék kifejezést illesztettük a tulajdonnévhez, jelezve, hogy a hegyet és a hegyperemi térséget egy tájkarakteregységnek tekintjük (pl. Zemplén-Tokaji-hegyvidék, Mátra-vidék, Bakony-vidék).

A dombságok esetében a dombvidék kifejezést illesztettük a tulajdonnévhez, olykor a középtáj szintnél részletesebb tagolást alkalmazva (Gödöllői-dombvidék). Ott vezettünk be a kistáj szintű földrajzi felosztásából származó, további területi bontást, ahol adott terület tájtípusmintázata ezt indokolta.

A síkságoknál megtartottuk az egyszavas megnevezést a -ság, -ség, illetve a -föld vagy a -köz végződésú tájneveknél. Itt ezek a képzők, illetve utótagok már utalnak a térség mivoltára, valamint megegyeznek a néprajzi tájnevekkel (Hajdúság, Nyírség, Mezőföld, Rábaköz). Azokban az esetekben, ahol az alapkőzet jellegadó szerepet kapott a tájmintázat alakításában és ez a földrajzi tájnévben is szerepel, ott ezeket a neveket szerepeltettük a tájkarakter-terület esetében is (Duna-Tisza-közi homokhátság, Kiskunsági löszhát). A folyó menti területeket egységesen a mente kifejezéssel jelöltük, többnyire, de nem minden esetben a földrajzi tájnévvel szintén megegyezően (Felső-Tisza mente, Rába mente). Önálló és minden tudományos és köznyelvi megközelítésben önálló tájként szerepel a Hortobágy.

Sajátos, de mindenképpen önálló tájkarakter-területet képviselő térségek a nagyvárosi agglomerációk, amelyek közül több (Budapest, Pécs, Miskolc) eltérő domborzatú nagytájak határain fekszik, vagy folyók mentén települt. Egyértelmú, hogy Budapest kettéválasztva nem mosható egybe sem a Duna menti síksággal, sem a Dunazug-hegyvidékkel, sőt ez utóbbiba olvadna be a sajátosan egyedi Dunakanyar is. Önálló tájkarakter-területnek tekintettük azokat a térségeket, ahol a várossal fokozatosan összenövő falvak és szórványok alkotta települési táj az uralkodó, illetve a városok a szomszédos üdülőtájakkal agglomerálódnak (Pécs agglomerálódó térsége, Budapest és a Dunakanyar agglomerálódó térsége, Székesfehérvár és a Velencei-tó agglomerálódó térsége). 

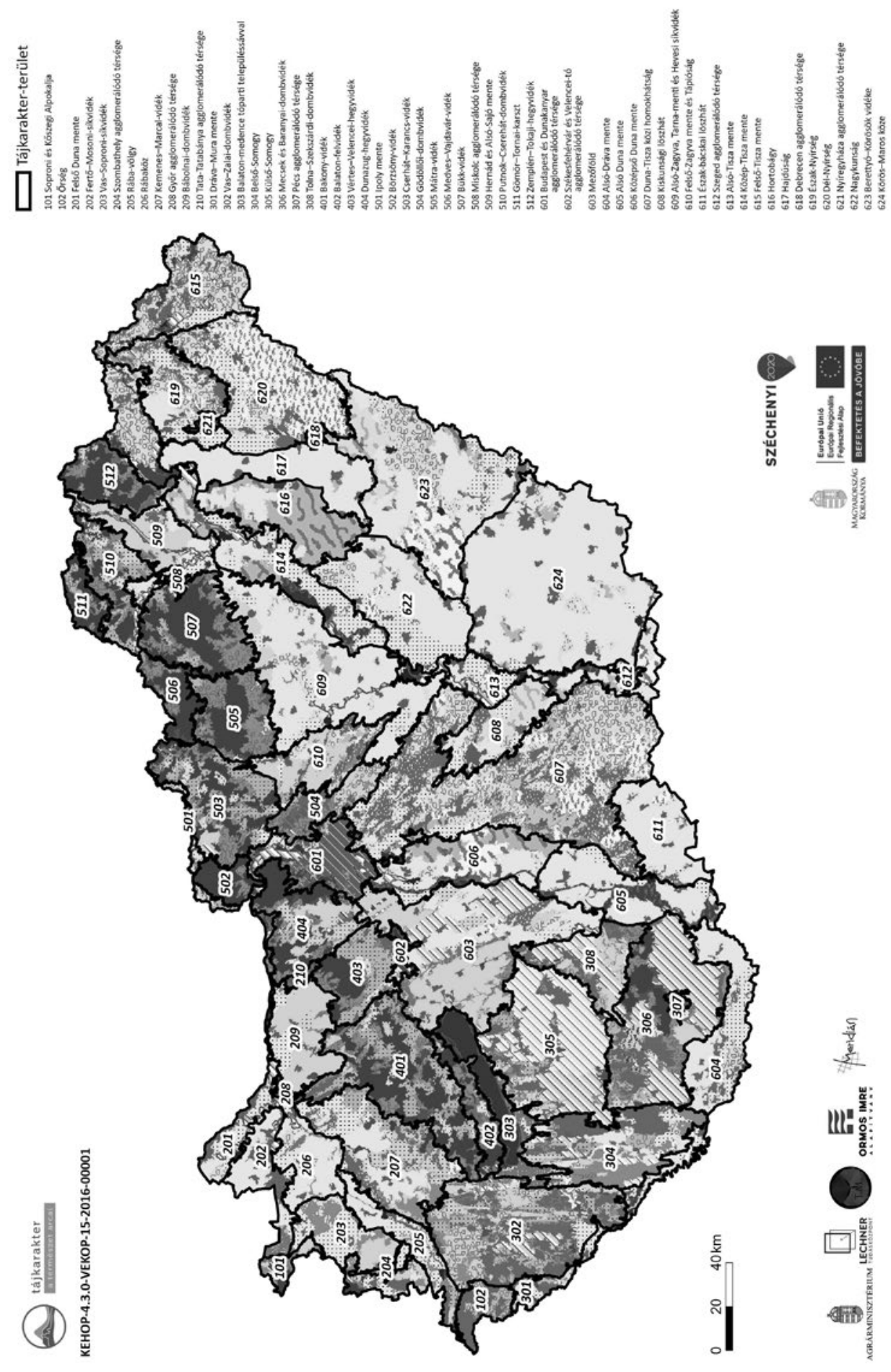


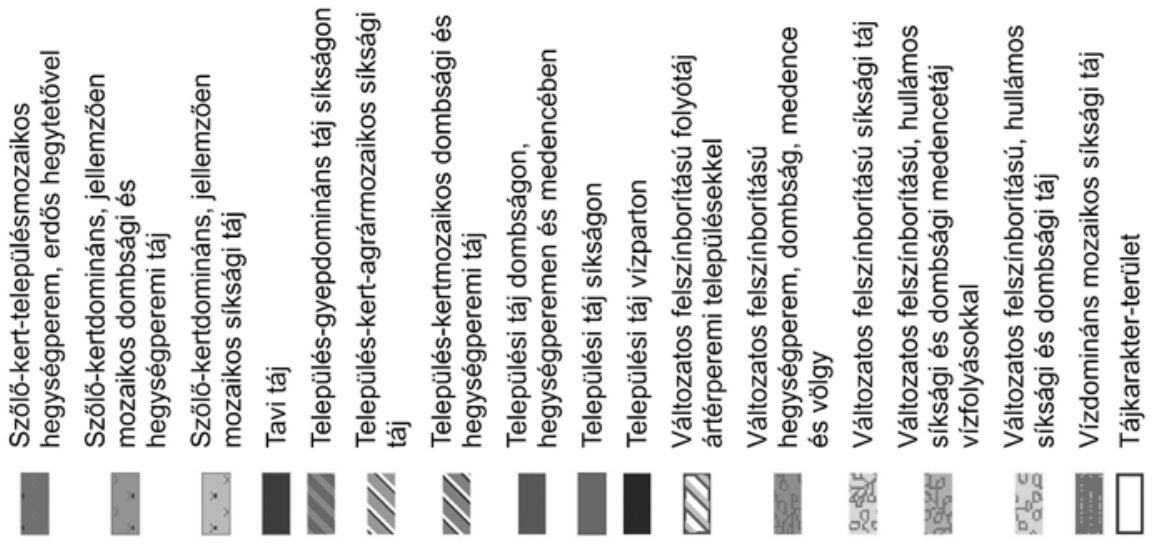

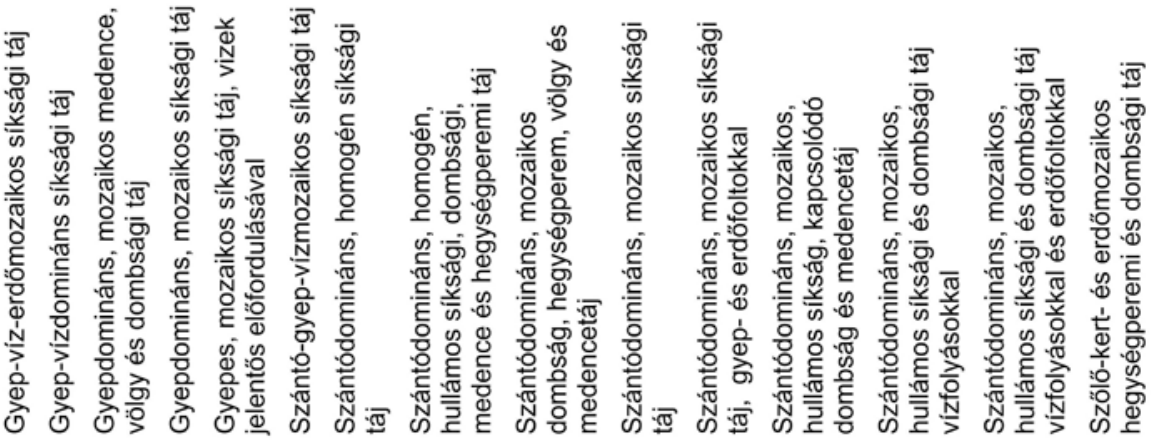

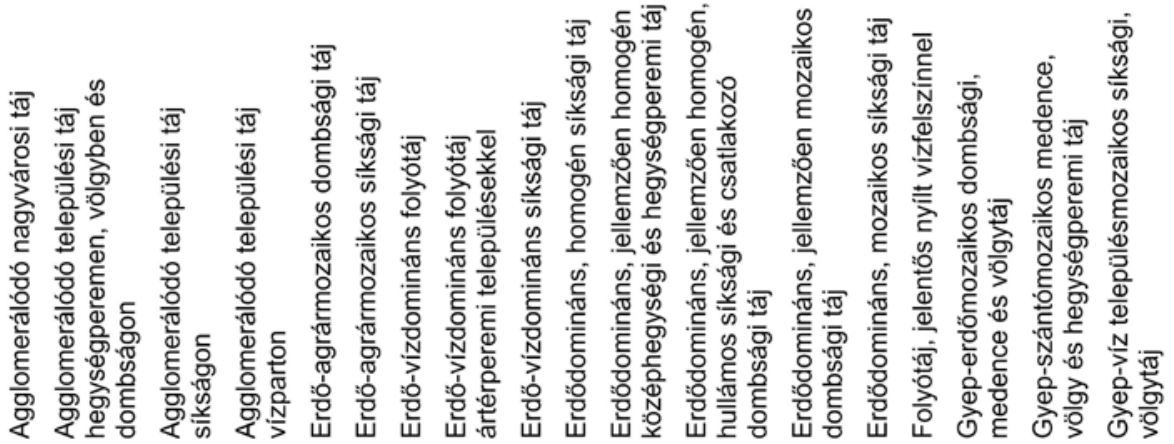


A tájkarakter-területek jellemzőit az előforduló tájkaraktertípusok és az egyes, az elemzésben alkalmazott lehatároló és leíró indikátorok alapján mutattuk be és a Tájkarakter tudástárban (KonKOLY-GYURó É.-Csőszi M. 2021) tettük közzé. Ez a megközelítés egy elsősorban térképekből és statisztikákból álló információtár létrehozását jelenti, ami annak a jövőben végleges formában kialakítandó tudástárnak a megalapozása és első lépése, amely akkor lesz teljes és végleges, amikor a kistáj léptékú részletes elemzések is megtörténnek, és a megbízhatóság azokból származó egyértelmú igazolása (validáció), valamint a terepi felméréseken alapuló tájjellemzések is becsatornázhatók lesznek az országos lehatárolásba és leírásba.

\section{A mintaterületi elemzés eredményei}

A mintaterületeken tájkarakter-altípusokat és néhány helyi tájmozaikegységet különítettünk el. Kistáj és helyi szinten az ország egyes tájain eltérő sajátosságok emelendők ki, mindig az adott térség kulcsjellemzőinek megfelelően. A 3. ábra és az 1. táblázat a Sopron-Fertő mintaterület országos tájkaraktertípusait, valamint a kistáj szintű altípusokat és tájkarakter-területeket mutatják.

Itt a következő meggondolások alapján végeztük a típusmeghatározást.

- Települési tájak esetében a városias, illetve falusias jelleget, a városiasodást, a települések összeépülését, a városperem átalakulását, illetve a speciális felszínformákhoz kötődő előfordulásokat (pl. medenceperem) vettük figyelembe.

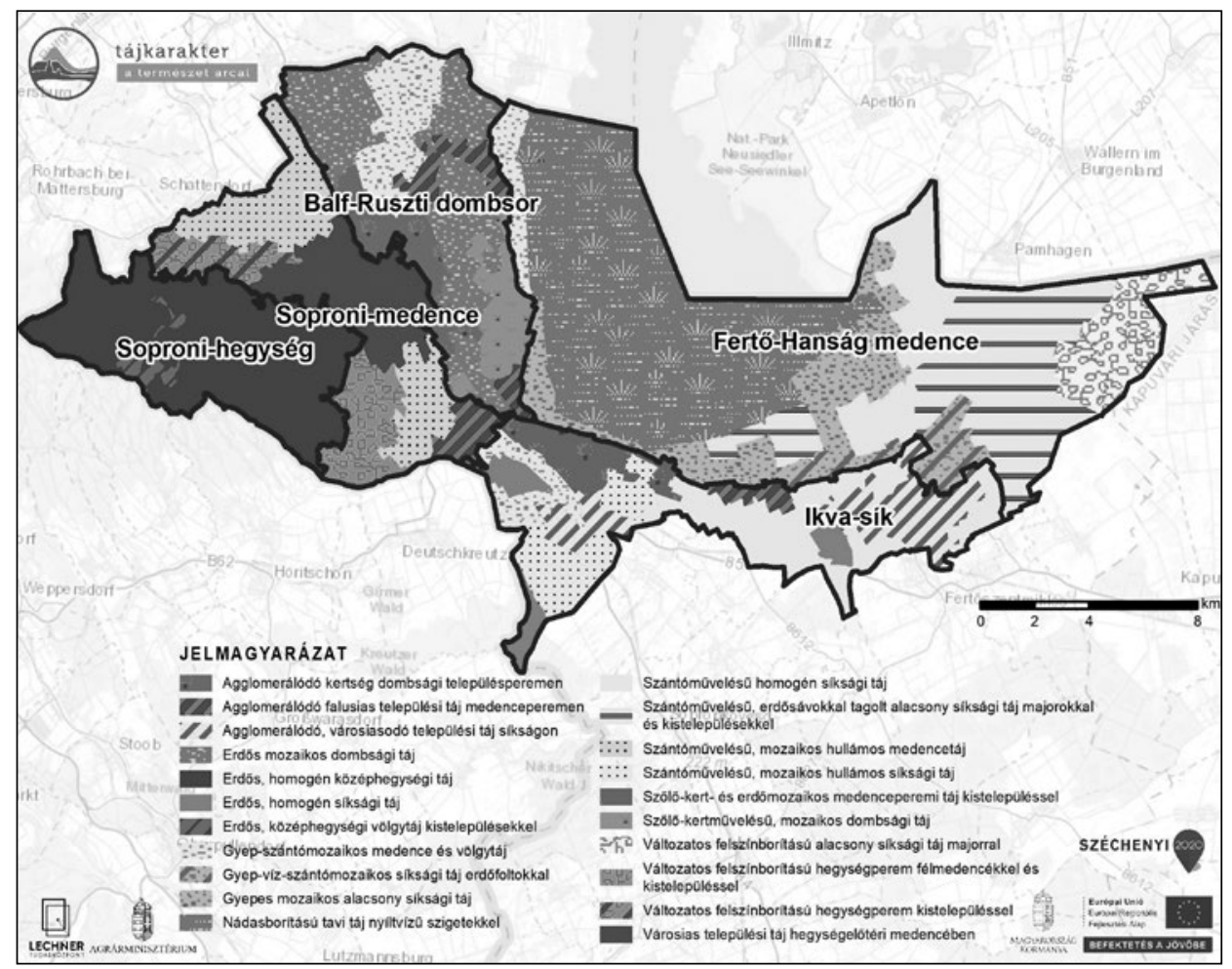

3. ábra Kistáj szintú tájkaraktertípusok és tájkarakter-területek a Sopron-Fertô mintaterületen Figure 3 Small landscape character types and areas in the Sopron-Fertő sample area 
A kistáj szintű tájkaraktertípusok előfordulásának példái

a Sopron-Fertő mintaterületen

Examples for small landscape character types

in the Sopron-Fertő sample area

\begin{tabular}{|c|c|c|c|c|c|}
\hline $\begin{array}{l}\text { Szám- } \\
\text { kód }\end{array}$ & $\begin{array}{l}\text { Tájkarakter- } \\
\text { fötípus }\end{array}$ & $\begin{array}{l}\text { Szám- } \\
\text { kód }\end{array}$ & $\begin{array}{l}\text { Tájkaraktertípus } \\
\text { országos szint }\end{array}$ & $\begin{array}{l}\text { Sor- } \\
\text { szám }\end{array}$ & $\begin{array}{c}\text { Tájkarakter-altípus } \\
\text { kistáj szint }\end{array}$ \\
\hline 1 & $\begin{array}{l}\text { Települési } \\
\text { és ipartáj }\end{array}$ & 121 & $\begin{array}{l}\text { Agglomerálódó tele- } \\
\text { pülési táj síkságon }\end{array}$ & 1. & $\begin{array}{l}\text { Agglomerálódó, városiaso- } \\
\text { dó települési táj síkságon }\end{array}$ \\
\hline 1 & & 123 & $\begin{array}{l}\text { Agglomerálódó tele- } \\
\text { pülési táj hegység- } \\
\text { peremen, völgyben } \\
\text { és dombságon }\end{array}$ & 2. & $\begin{array}{l}\text { Agglomerálódó } \\
\text { kertség dombsági } \\
\text { településperemen }\end{array}$ \\
\hline 1 & & 133 & $\begin{array}{l}\text { Települési táj domb- } \\
\text { ságon, hegységpere- } \\
\text { men és medencében }\end{array}$ & 3. & $\begin{array}{l}\text { Urbánus települési táj } \\
\text { hegységelőtéri medencében }\end{array}$ \\
\hline 2 & Agrártáj & 211 & $\begin{array}{l}\text { Szántódomináns, } \\
\text { homogén síksági táj }\end{array}$ & 4. & $\begin{array}{l}\text { Szántódomináns, } \\
\text { homogén síksági táj } \\
\text { kistelepülésekkel }\end{array}$ \\
\hline 2 & & & & 5. & $\begin{array}{l}\text { Szántódomináns, erdő- } \\
\text { sávokkal tagolt, alacsony } \\
\text { síksági táj majorokkal és } \\
\text { kistelepülésekkel }\end{array}$ \\
\hline 2 & & 232 & $\begin{array}{l}\text { Gyepdomináns, } \\
\text { mozaikos síksági táj }\end{array}$ & 6. & $\begin{array}{l}\text { Gyepdomináns, természet- } \\
\text { közeli, mozaikos alacsony } \\
\text { síksági táj }\end{array}$ \\
\hline 3 & Erdôs táj & 304 & $\begin{array}{l}\text { Erdődomináns, } \\
\text { jellemzően homogén } \\
\text { középhegységi és } \\
\text { hegységperemi táj }\end{array}$ & 7. & $\begin{array}{l}\text { Erdődomináns, } \\
\text { természetközeli, homogén } \\
\text { középhegységi táj }\end{array}$ \\
\hline 3 & & & & 8 & $\begin{array}{l}\text { Erdődomináns, } \\
\text { középhegységi völgytáj } \\
\text { kistelepülésekkel }\end{array}$ \\
\hline 4 & Vizi táj & 421 & Tavi táj & 9. & $\begin{array}{l}\text { Nádas borítású, } \\
\text { természetközeli tavi táj } \\
\text { nyílt vizú szigetekkel }\end{array}$ \\
\hline 5 & Változatos táj & 542 & $\begin{array}{l}\text { Szőlő-kert- és erdő- } \\
\text { mozaikos hegységpe- } \\
\text { remi és dombsági táj }\end{array}$ & 10. & $\begin{array}{l}\text { Szőlő-kert- és erdő- } \\
\text { mozaikos medenceperemi } \\
\text { táj kistelepülésekkel }\end{array}$ \\
\hline 5 & & & & 11. & $\begin{array}{l}\text { Változatos felszínborítású } \\
\text { alacsony síksági táj } \\
\text { majorokkal }\end{array}$ \\
\hline
\end{tabular}

- Az agrártájak és a változatos felszínborítású tájak esetében a domborzati formákat pontosítottuk, illetve a települések, vagy jellegzetes külterületi objektumok (pl. majorok) és az erdősávok, mint kulcsjellemzők előfordulását jeleztük. 
- Az erdős tájak esetében a nagy összefüggő erdőtömbökön belül a lakott völgyeket, vagy más jellegzetességek alapján elkülönülő domborzati, illetve geológiai formákat azonosítottuk önálló altípusként.

- A vízdomináns tájak esetében a kulcsjellemzőként megjelenő nádas borítást szerepeltettük a megnevezésben.

Az altípusképzésnél a természetközeliséget is jeleztük abban az esetben, ha az antropogén átalakítás mértéke a terepi felvételezés alapján alacsony szintű.

\section{Országos visszacsatolás és tájkaraktertípus-hierarchia}

A projekt keretében a négy mintaterületen végzett terepi felmérés lehetőséget adott az országos tájkaraktertípusok ellenőrzésére, szükség szerinti tartalmi, illetve geometriai pontosítására. Ebből a visszacsatolásból látható, hogy a pontosítás érintheti a felszínborítás-típusokat és a domborzati formákat is.

A felszínborítás esetében a jövőbeni tájmonitoring fontos szerepet kap. Itt különösen a települési tájak további elemzése, pontosítása és ezek változása kerülhet előtérbe. A felszíni vizek által meghatározott tájak esetében is szükséges ellenőrizni, hogy mely területre terjed ki ténylegesen a víz jelenlétének hatása (pl. holtágak, illetve ezek maradványai). Lényeges a mozaikosság felülvizsgálata is, mert a helyszíni felmérések esetében azonosíthatók a tájat tagoló, a homogenitást feloldó tájelemek (pl. kisvízfolyások, utak, zöldsávok), amelyek miatt a homogénként jelölt tájak mozaikos kategóriába sorolódhatnak át. Az országosan jelenleg nem lehatárolt, ipar és bányászat által uralt tájak azonosítása is a kistáji felmérések után történhet meg.

A domborzatot érintően az országosan egy típusba sorolt hegységi és hegységperemi tájak, valamint a síksági, a domb- és hegyperemi területek ellenőrzésének, szükség szerint kistáj szintú további bontásának kell megtörténnie. A medencék és a völgyek esetében is megállapítandó, hogy valójában melyek azok, amelyek önálló karakterû országos típusként vehetők számításba és melyeket lehet a hegységek, illetve dombságok részének tekinteni, mert nincs szembetűnő egyedi jellegük.

A tájkaraktertípusok és altípusaik hierarchiájának megalkotásakor szükség lehet a típusok és az altípusok besorolásának módosítására.

- Előfordul, hogy valamely országosan lehatárolt típust az altípusok közé sorolunk, mert ritkán érik el a $4 \mathrm{~km}^{2}$-es területi minimumot, azonban kisebb kiterjedésben jellegzetesen és sok helyen előfordulnak (pl. településperemi kertségek).

- A kistáj szinten azonosítandó tájkarakter-altípusok beillesztendók az országos hierarchiába, azaz valamely típus alá rendelendők.

- Az altípusképzés logikája, tartalma azon kulcsjellemzők alapján határozandó meg, amelyek kistáj szinten előfordulnak. Ilyenek lehetnek különösen a települések, illetve a szórványbeépítések jellege, a közlekedési hálózatok csomópontjai, a speciális üdülési, logisztikai létesítmények, az ipartelepek, a roncsolt felszínek, vagy a felhagyás.

- Lényeges szempont a tájtípus, vagy az altípus látvány alapján azonosítható természetközelisége, illetve átalakítottsága, ami nem azonos az élőhely ökológiai állapotával, hanem a tájrészlet vagy altípus egészében előforduló felszínborítás-típusok és a múvi elemek előfordulása, gyakorisága által határozható meg.

- A helyi (települési) lépték és a kistáj lépték között is különbséget kell tennünk, azaz egyes jellegzetes, de csak helyi szinten értelmezhető, kis kiterjedésű $\left(1 \mathrm{~km}^{2}\right.$ alatti) tájrészleteket nem altípusba, hanem tájmozaikegység kategóriába sorolunk (pl. kereskedelmi zónák, vagy ipartelepek településperemen, bányatavak körüli üdülőtelepek stb.). 
A projekt keretében 50 országos tájkaraktertípust és a négy mintaterületen végzett felmérések által meghatározott 71 tájkarakter-altípust azonosítottunk. Az 50 országos tájkaraktertípusból 36 megtalálható a mintaterületek valamelyikében, és ezeknek a vizsgált térségben előforduló altípusait is azonosítani tudtuk. Az ország többi részén természetesen további altípusok fordulhatnak elő, így ezek listája távolról sem végleges.

\section{Összefoglalás}

A kutatás keretében megalkottuk a hazai tájkarakter alapú térrendszert, az ország egész területét lefedően. Létrehoztuk a több léptékben, illetve területi szinten alkalmazható tájkarakter-téregységek hierarchiarendszerét és lehatárolásuk, leírásuk és értékelésük koherens fogalomrendszerét, módszertanát. Megtörtént a tájkaraktertípusok és a tájkarakter-területek azonosítása, határaik irányadó (indikatív) kijelölése és leírásuk a földrajzi középtájak léptékében az ország teljes területére. Elvégeztük továbbá négy mintaterületen a tájkarakter-altípusok és a kistáj szintű tájkarakter-területek lehatárolását, leírását és értékelését, valamint ezek alapján megtettük a visszacsatolást az országos szintre. Bemutattuk a tájkarakter-elemzési folyamatban alkalmazható sokrétú eszköztárat, ami kiterjed a térinformatikai vizsgálatokra, a terepi tájfelmérésre és az érintettekkel folytatott párbeszédre, valamint ezek mindegyikét felhasználó tájváltozási folyamatok elemzésére és értékelésére. Javaslatot tettünk hazai tájak változásának hosszú távú, országos léptékű nyomon követéséhez szükséges egységes tájmonitoring-rendszer megteremtésének kialakítására és az eredmények felhasználására. Mindezeket a projekt honlapján elérhető Tájkarakter tudástárban, Tájkarakter határozóban és az alkalmazási lehetőségeket összefoglaló kiadványban tettük közzé.

A kutatás során elkészült tudásanyag felhasználásnak négy iránya, területe jelölhető ki: tervezés, kutatás, igazgatás és szemléletformálás. Minden itt jelzett témakörben több területi szinten jelennek meg a feladatok és ezek mindegyikét támogatják a tájkaraktertéregységekhez köthetó információk, így az országos, a térségi (regionális, megyei és kistérségi), a települési és az egyedi objektumok szintjét is. Azonban, amint a bevezetőben is jeleztük, nem lezárt folyamatról van szó. Az itt említett első eredmények a megalapozását jelentik annak a reményeink szerint a geográfusok további részvételével folytatandó munkának, amelynek során a teljes országterületen elkészülhetnek a részletes kistáji és helyi szintú tájkarakter-elemzések. Utóbbiak részét kell képeznie a percepcionális felméréseknek a helyi érintettek bevonásával, amely által pontosítható lesz az országos lehatárolás is. Érdemes figyelembe venni, hogy Nagy-Britanniában közel félévszázados múltra tekint vissza a tájkarakter-elemzés.

Jelen tanulmány keretében nem érinthettünk minden témakört. Ezért tervezzük a tájkarakter-kutatásról szóló összefoglaló folytatását, a kistáj szintű tájkarakter-elemzés és -értékelés témakörében, valamint a felhasználási területek, különösen a földrajztudományban történő alkalmazás részletes kifejtésével.

\section{Köszönetnyilvánítás}

A kutatás a Közösségi jelentőségü természeti értékek hosszú távú megörzését és fejlesztését, valamint az EU Biológiai Sokféleség Stratégia 2020 célkitüzéseinek hazai megvalósítását megalapozó stratégiai vizsgálatok címú KEHOP 4.3.0 - VEKOP 15-2016-00001 számú projekt keretében készült. A cikk szerzői köszönetet mondanak a projektgazda 
Agrárminisztérium munkatársainak, és a közreműködő szakértőknek, a Lechner Tudásközpont, a Tájmúhely Kft és az Ormos Imre Alapítvány munkatársainak.

KONKOLY-GYURÓ ÉvA

Soproni Egyetem Környezet- és Földtudományi Intézet, Sopron

Lechner Tudásközpont Nonprofit Kft., Budapest

konkoly-gyuro.eva@uni-sopron.hu

VASZÓCSIK VILJA

Lechner Tudásközpont Nonprofit Kft., Budapest

vilja.vaszocsik@lechnerkozpont.hu

CSORBA PÉTER

Debreceni Egyetem Tájvédelmi és Környezetföldrajzi Tanszék, Debrecen

csorba.peter@science.unideb.hu

SCHNELLER KRISZTIÁN

Lechner Tudásközpont Nonprofit Kft., Budapest

krisztian.schneller@lechnerkozpont.hu

JOMBACH SÁNDOR

Ormos Imre Alapítvány, Budapest

Magyar Agrár- és Élettudományi Egyetem Tájépítészeti, Településtervezési

és Díszkertészeti Intézet, Budapest

jombach.sandor@tajk.szie.hu

BOROMISSZA ZsOMBOR

Ormos Imre Alapítvány, Budapest

Magyar Agrár- és Élettudományi Egyetem Tájépítészeti, Településtervezési

és Díszkertészeti Intézet, Budapest

zsombor.boromisza@gmail.com

ERDEI TÍMEA

Ormos Imre Alapítvány, Budapest

Magyar Agrár- és Élettudományi Egyetem Tájépítészeti, Településtervezési és Díszkertészeti Intézet, Budapest

erdei.timea@tajk.szie.hu

KesZThelyi Ákos

Ormos Imre Alapítvány, Budapest

Magyar Agrár- és Élettudományi Egyetem Tájépítészeti, Településtervezési

és Díszkertészeti Intézet, Budapest

Keszthelyi.akos@tajk.szie.hu

BALÁZS PÁL

Soproni Egyetem Környezet- és Földtudományi Intézet, Sopron

balazs.pal@uni-sopron.hu

KISS DÁNIEL

Lechner Tudásközpont Nonprofit Kft., Budapest

daniel.kiss@lechnerkozpont.hu 
TeleKi MóNIKA

Lechner Tudásközpont Nonprofit Kft., Budapest

monika.teleki@lechnerkozpont.hu

BÁNHIDAI ANDRÁS

Lechner Tudásközpont Nonprofit Kft., Budapest

andras.banhidai@lechnerkozpont.hu

CsŐSZI MÓNIKA

Lechner Tudásközpont Nonprofit Kft., Budapest

monika.csoszi@lechnerkozpont.hu

\section{IRODALOM}

Antrop, M.-VAN EetVElde, V. 2017: Landscape perspectives. The holistic nature of landscape. - Landscape Series 23. Springer Netherlands, Dordrecht. XV + 436 p.

Az Európa Tanács Táj Egyezménye (Council of Europe Landscape Convention). - In: 2018. évi LIX. törvény az Európai Táj Egyezményt módosító Jegyzőkönyv kihirdetéséről és a Firenzében, 2000. október 20-án kelt, az Európai Táj Egyezmény kihirdetéséről szóló 2007. évi CXI. törvény módosításáról. https://mkogy.jogtar.hu/jogszabaly?docid=A1800059.TV

Countryside Agency 1999: Countryside character: The character of England's natural and man-made landscape 1-8. - Countryside Commission, Cheltenham.

Countryside Commission 1987: Landscape assessment - a Countryside Commission approach. - CCD 18. Cheltenham.

CSEmez A. 1997. Tájtervezés-tájrendezés. - Mezőgazda Kiadó, Budapest. 296 p.

Csorba P. (szerk.) 2018: Tájak - In: Kocsis K. (főszerk.): Magyarország nemzeti atlasza. Természeti környezet. MTA Csillagászati és Földtudományi Kutatóközpont Földrajztudományi Intézet. Budapest. pp. 112-129.

Csorba P.-NAGY I.-CsÜLlÖG G. 2018: A földrajzi tájak tipizálása európai kitekintéssel.-Földrajzi Közlemények 142. 4. pp. 272-290.

DövÉNYI Z. (szerk.) 2010: Magyarország kistájainak katasztere. - MTA Földrajztudományi Kutatóintézet, Budapest. $876 \mathrm{p}$.

Európai Táj Egyezmény (European Landscape Convention). - In: 2007. évi CXI. törvény a Firenzében, 2000. október 20-án kelt, az Európai Táj Egyezmény kihirdetéséről. https://net.jogtar.hu/jogszabaly?docid=a0700111.tv

FAirclough, G.-SARLÖv Herlin, I.-SwANwick, C. (szerk.) 2018: Routledge handbook of landscape character assessment. Current approaches to characterisation and assessment. - Routledge. New York. XIX + 294 p.

Forman, R. T. T. 1995: Land mosaics: The ecology of landscapes and regions. - Cambridge University Press. Cambridge. $\mathrm{XX}+632 \mathrm{p}$.

Konkoly-Gyuró É.-TirÁszi Á.-WrbKA, T.-PrinZ, M.-Renetzeder, C. 2010: Határon átívelő tájak karaktere. A Fertő-Hanság medence és Sopron térsége. Der Charakter grenzüberschreitender Landschaften. Das Neusiedlersee-Waasen-Becken und die Region Sopron. - Nyugat-Magyarországi Egyetem Kiadó, Sopron. 43 p.

KonKOLY-GyuRó É. 2013: Tájökológiai és -tervezési glosszárium. - Tájmúhely Táj- és Környezetkutató, Tervező és Tanácsadó Kft. Budapest. 39 p. http://mek.oszk.hu/11500/11584/11584.pdf

KonKoly-Gyuró É. (szerk.) 2021: Tájkarakter határozó. Kutatási jelentés. A közösségi jelentőségú természeti értékek hosszú távú megórzését és fejlesztését, valamint az EU biológiai sokféleség stratégia 2020 célkitűzéseinek hazai szintû megvalósítását megalapozó stratégiai vizsgálatok (KEHOP-4.3.0VEKOP-15-2016-00001) Tájkarakter fejlesztési eleme. - Agrárminisztérium. Budapest.

KonKoly-Gyuró É.-Csőszi M. (szerk.) 2021: Tájkarakter tudástár. Kutatási jelentés. A közösségi jelentőségű természeti értékek hosszú távú megőrzését és fejlesztését, valamint az EU biológiai sokféleség stratégia 2020 célkitűzéseinek hazai szintû megvalósítását megalapozó stratégiai vizsgálatok (KEHOP-4.3.0VEKOP-15-2016-00001) Tájkarakter fejlesztési eleme. - Agrárminisztérium. Budapest.

Natural England 2014: National character area profiles. https:/www.gov.uk/government/publications/nationalcharacter-area-profiles-data-for-local-decision-making

Nemzeti Tájstratégia (2017-2026). - Földmúvelésügyi Minisztérium, Budapest. 85 p. https://2015-2019.kormany.hu/download/8/ff/f0000/Nemzeti\%20T\%c3\%a1jstrat\%c3\%a9gia_2017-2026. pdf\#!DocumentBrowse 
Raymond, R.-LuginbüHL, Y.-Seguin, J.-F.-Cedelle, Q.-GRARE, H. 2015: Landscape Atlases. Landscape identification, characterisation and assessment method. - Ministère de l'Écologie, du Développement durable et de l'Énergie. $111 \mathrm{p}$.

Simensen, T.-Halvorsen, R.-Erikstad, L. 2018: Methods for landscape characterisation and mapping: A systematic review. - Land Use Policy 75. pp. 557-569. https://doi.org/10.1016/j.landusepol.2018.04.022.

SwANwICK, C.-Land use consultants 2002: Landscape character assessment - Guidance for England and Scotland. - The Countryside Agency and Scottish Natural Heritage. 104 p.

WASCHER D. M. (szerk.) 2005: European landscape character areas. Typologies, cartography and indicators for the assessment of the sustainable landscapes. Final project report. - Landscape Europe, Alterra Wageningen University Research, Wageningen. X + 150 p. https://edepot.wur.nl/1778 


\title{
A NYUGAT-MECSEK FELSZÍNI KARSZTJA
}

\author{
VERESS MÁRTON
}

THE SURFACE KARST OF THE WESTERN MECSEK

\begin{abstract}
In this study, the surface karst of the Western Mecsek is overviewed based on literary data. Non-karstic features (abrasion platforms, epigenetic valleys) and karstic features are also taken into consideration. Its karst features are solution dolines, subsidence dolines, point recharge dolines and concretions. The specific characteristics of the dolines of the karst are their large density, the arrangement of solution dolines into rows, and the fact that solution dolines are not situated on valley floors. The occurrence of subsidence dolines can largely be related to solution dolines. The morphometry of dolines shows differences from the morphometry of the dolines of the karst of the Aggtelek Mountains and of the karst of the Bükk Mountains.
\end{abstract}

Keywords: abrasion platform, solution doline, doline row, subsidence doline, point recharge doline

\section{Bevezetés}

Ebben a tanulmányban a Nyugat-Mecsek felszíni karsztját tekintjük át irodalmi adatok felhasználásával.

A Mecsekvidék kistájcsoport, amely a Mecsek és a Tolna-Baranyai-dombvidék középtáj része. A Mecsekvidék a Mecsek-hegység és a Baranyai-Hegyhát kistájakra különül (DöVÉNYI Z. 2010), karszt a Mecsekben van.

A Mecsek-hegység területe $350 \mathrm{~km}^{2}$, DDNy-ÉÉK-i irányú tönkök rendszere, magassága 300-600 m közötti. A Nyugati-Mecsek tönkös sasbércek sorozata a Keleti-Mecsek a Dobogó-Zengő csoportból sugarasan kiágazó sasbérc sorokból épül fel. A hegység formái a hegylábi félsíkok, törmelékkúpok és eróziós völgyek. Karsztja a Nyugati-Mecsek területének északi részén fejlődött ki, mintegy $30 \mathrm{~km}^{2}$-en. A Nyugati Mecsek egy NY-K csapású antiklinális. Felépítő kőzetei É-ról D-i irányban haladva: anizuszi, vékonyréteges, gumós mészkő (Lapisi Mészkő Formáció,Zuhányai Mészkő Formáció), dolomit (Rókahegyi Dolomit Formáció), amelyet vastagabb dolomit és más kőzetekből felépülő sáv (Hetvehelyi Dolomit Formáció) követ (HAAS J. 1994). E terület kárpáti korú hegylábfelszín. Két részre különül: egy magasabbra (450-470 m), amely középső-miocén korú (LovÁsz Gy. 1981 helvét) abráziós terasz és egy alacsonyabbra (250-380 m). Ez utóbbi tektonikusan feldarabolódott pannon korú (felső pannon), ugyancsak abráziós terasz (LovÁsz Gy. 1971; HeVESI A. 2001, 1. ábra). Karsztja három részre különül: a Szuadó-völgytől nyugatra az Abaligeti-, keletre az Orfúi- és a Misina-Tubes-karszt (Melegmány) területére (LovÁsz GY. 1977).

A karszt leggyakoribb, legjellegzetesebb formái a dolinák (JAKUCS L. 1980; JAKUCS L et al. 1983), így az oldódásos a point recharge- és az utánsüllyedéses dolinák. Az oldódásos dolinák közül legelterjedtebbek a drawdown dolinák. Kialakulásuk a következő: a vízbepótlás miatt az epikarszt járatai szélesednek, ezért gyorsul a vízelvezetés, ami az epikarszt fejlődését tovább gyorsítja. Ez fokozza a felszíni oldódást és e helyeken a felszín mélyülését. Emiatt e helyekre több víz áramlik, amely a fenti folyamatok intenzitását tovább növeli (WiLliams, P. W. 1985, 2004; Ford, D. C.-Williams, P. W. 2007). A point recharge dolinák völgytalpiak. E típus dolináit a völgy időszakos, vagy állandó vízfolyásai táplálják és okozzák fejlődésüket (Williams, P. W. 2004; ForD, D. C.-Williams, P. W. 


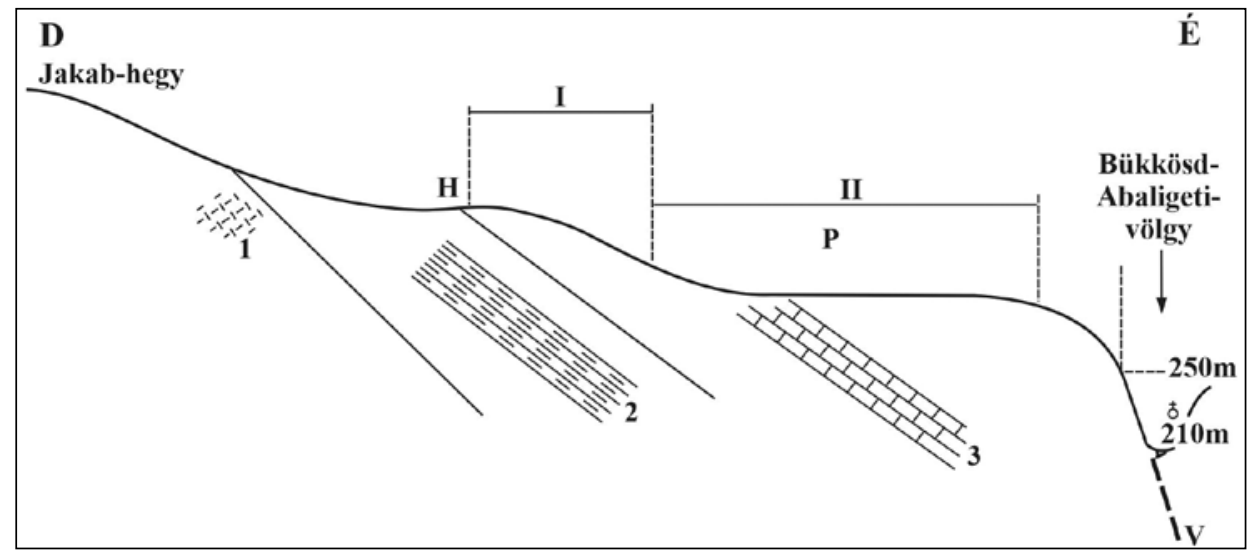

1. ábra A mecseki karszt földtani és morfológiai szelvénye (Lovász Gy. 1971).

- H - Középső-Miocén abráziós terasz; P - Pliocén abráziós terasz; I - ritkán települt nagy dolinák zónája; II - sűrűn települt nagy dolinák zónája;

1 - permi homokkő és triász dolomit; 2 - alsó triász mészkő; 3 - középső triász mészkő; V - vető

Figure 1 Geological and geomorphological section across the Mecsek karst (LovÁsz, Gy. 1971).

- H - Middle Miocene abrasion platform; P - Pliocene abrasion platform; I - zone of large dolines of low density; II - zone of large dolines of high density;

1 - Permian sandstone and Triassic dolomite; 2 - Lower Triassic limestone; 3 - Middle Triassic limestone; V - fault

2007; SAURO U. 2012). Az oldódásos dolinák akárcsak a point recharge dolinák a csupasz vagy talajos mészkőfekü depressziói (WiLliams P. W. 2004; Veress M. 2018). Az utánsüllyedéses dolinák a karszt fedőjében alakulnak ki szuffózióval (szuffóziós dolina), vagy omlással (lezökkenéses dolina, WILLIAMS, P. W. 2004; VERESS, 2016). Ha az utánsüllyedéses dolina járata idősebb, mint a depressziója, akkor posztgenetikus, ha egyidősek, akkor szingenetikus a dolina (VERESS M 2016).

\section{Általános jellemzők}

A mecseki karszt karsztosodásának általános jellemzésével SzABÓ P.Z. (1968); JAKUCS L. (1977); BARTA T.-TARNAI K. (1997); HeVESI A. (1991, 2001); Veress M. (2011, 2016) foglalkozott. Felszíni karsztformáit HEVESI A. (1991, 2001); BARTA T.-TARNAI K. (1991); Veress M. (2011); VetÉsi-FoITH Sz. et al. (2017), a formák eloszlását LovÁsz Gy. (1971, 1977), mintázatát LovÁsz GY. (1977); CZIGÁNY Sz.-LovÁsz GY. (2006), morfometriáját HoYK E. (2002); LipPMANn L. et al. (2008); KEVEINÉ BÁRÁNY I. et al. (2015) vizsgálta. Mésztufáiról Kraft J. et al. (1986); Koltai G. et al. (2012) közölt adatokat.

A karszt vegyes autogén-allogén karszt, miután D-ről homokkő és rosszul karsztosodó mészkő, valamint dolomit sávok határolják (BARTA T.-TARNAI K. 1997), de K-i része (MisinaTubes-karszt) CZIGÁNY Sz.-LovÁsz Gy. (2006) szerint nem, hanem kiemelt helyzete miatt autogén karszt. Miután a teljes mecseki karszt autogén részét lösz fedi, uralkodóan rejtett karszt (HEVESI A. 2001). Északra dőlő felszínét átmenő völgyek tagolják, amelyek jobbára a nem karsztos térszínről indulnak, majd áthaladva a karszton, annak É-i peremén futnak ki területéről (HEVESI A. 2001) és a Bükkösdi-vizet, Orfúi-patakot vagy Baranya-patakot táplálják. Ezért Veress M. (2016) fél allogén fedett karsztnak nevezi a Mecseki karsztot.

A karsztterület fedője elsősorban würmkori lösz (HEVESI A. 2001), de a VESZ (Vertikális Elektromos Szondázás) mérések adatai szerint elófordul homok, agyag is, főleg a löszbe települve, vagy keverten mint homokos lösz mészkőtörmelékkel. A lösz szinte egységes 
kifejlődésben borítja 1-2 m vastagságban a karsztot. É-i irányban vastagodva helyenként a 3-4 m-t is eléri (LiPPMANN L. et al. 2008), de jelentősen kivastagodhat (elérheti a 10 m-t is) egy-egy oldódásos dolinában.

A völgyek, amelyek kialakulása a pleisztocén előtt kezdődhetett (LovÁsz Gy. 1977; Hevesi A. 2001), de a pannonnál később, kétféleképpen jöhettek létre. Átöröklődéssel (a mellékvölgyek hiánya arra utalhat, hogy az átöröklődés főleg a sávokban meglévő fedőről történhetett), vagy fedő hiányában átöröklődés nélkül, ha a karsztvízszint a karszt felszínénél helyezkedett el.

Karsztformái az alábbiak: oldódásos (drawdown) dolinák, uvalák, utánsüllyedéses dolinák, víznyelők (point recharge dolinák), kiválások. A két dolinatípust a különböző szerzők nem különítik el genetikailag, hanem az utánsüllyedéses dolinákat mindössze kisebb méretüknél fogva és a különböző morfometriai jellemzők figyelembevételével fiatalabbnak tartják (KEVEINÉ BÁRÁNY I. et al. 2015). Gyakran a két dolinatípust összevontan vizsgálják, ezért különböző jellemzőikre többnyire csak együttes, közös adat adható meg.

\section{A karsztformák elterjedése és morfometriája}

A karsztos depressziók gyakorisága, mérete D-ről É-ra, valamint K-ről Ny-ra (általában a karszt egészén), de különösen az Abaligeti-karszton nő (LovÁsz Gy. 1971). A karsztos depreszsziók az alsó, fiatalabb abráziós felszínen az elterjedtebbek (Lovász Gy. 1977; LiPPMANN L. et al. 2008). De a dolinák mindkét típusa (különösen az Orfúi-karszton) a két teraszt elválasztó lejtőn is jelen van, a felsô szinten csak utánsüllyedéses dolinák fordulnak elő (LovÁsz Gy. 1971, 1977). A felső szint dolinákban szegénységét (vagy hiányát) Lovász Gy. (1971) itt a mészkő kis vastagságával magyarázta. Szerinte a kis vastagságú mészkő nem kedvezett a karsztformák képződésének. A kis vastagság arra vezethető vissza, hogy a karsztot D-ről határoló és É-nak dőlő nem karsztos kőzetek itt még a felszínhez közeli helyzetúek (1. ábra).

A dolinák 260-552 m magasságok között fordulnak elő, többségük 260-380 m közötti magasságú felszínen, de csak ha az alsó abráziós terasz dolináit tekintjük, akkor e térszín dolinái 280-310 m magasságok közt csoportosulnak (LIPPMANN L. et al. 2008).

A karszt Ny-i részén a völgyek közül a Körtélyesnek és a Szuadónak nincs mellékvölgye. HeVEsi A. (2001) kapcsolatot lát a mellékvölgyek megléte (illetve hiánya) és a dolinasûrűség között. Szerinte a dolinasűrűség az olyan völgyközi hátakon nagy, ahol a hátakat határoló völgyeknek nincs mellékvölgye és az olyan hátakon kicsi, ahol vannak mellékvölgyek. (Sajnos nem ismeretes, hogy a dolinasűrűség számításánál csak az oldódásos-, vagy az utánsüllyedéses dolinákat is figyelembe vette-e?).

A mecseki karszt legfőbb jellegzetessége, hogy a magyarországiak közül itt a legnagyobb a dolinasűrűség. Amíg az Aggteleki-karszton a dolinasûrűség 9,7 db/km² (TELBISz T. 2001), addig HEVESI A. (2001) szerint az Orfúi-karszton (Zsidó-völgy közelében) a dolinasûrűség 73,4 km². LiPPMANN L. et al. (2008) szerint a dolinák zöme, $1227 \mathrm{db}$, a karszt $22,7 \mathrm{~km}^{2}$ kiterjedésű területén található. LIPPMANN L. et al. (2008) szerint a dolinasûrűség az Abaligeti-karszton több helyen eléri a $80 \mathrm{db} / \mathrm{km}^{2}-\mathrm{t}$ (2. ábra), de az Orfúi-karszt egy $2 \mathrm{~km}^{2}$-es területén a sûrűség $164 \mathrm{db} / \mathrm{km}^{2}$. A fentitôl eltérő dolinaszámról közöl adatot HоYк E. (2002). Az általa vizsgált $14 \mathrm{~km}^{2}$-es kiterjedésű területen $1540 \mathrm{db}$ dolina van, és a dolinasűrúség eléri a $380 \mathrm{db} / \mathrm{km}^{2}$-t. Az eltérés oka, hogy előző tanulmányban az adatokat térképről $(\mathrm{M}=1: 10000)$ nyerték (amelyen a legkisebb méretűeket nem tüntették fel) míg utóbbiban terepbejárás során, így valószínúleg a kisebbek is figyelembe lettek véve. Ezen nagy dolinasűrűségi értékek csak azzal magyarázhatók, hogy a dolinák többségét a kisméretú dolinák, tehát az utánsüllyedéses dolinák (ld. alább) teszik ki. 


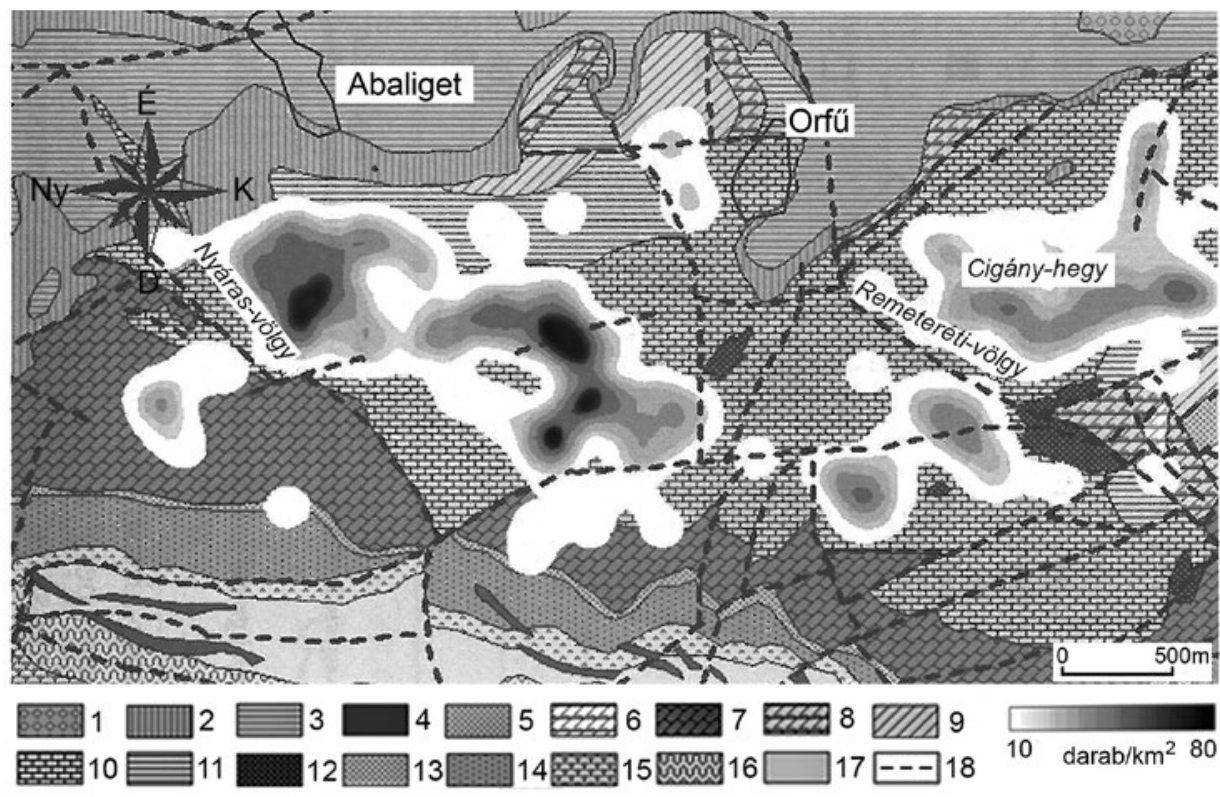

2. ábra Dolinasúrúségek (LiPPMANN L. et al. 2008). - 1 - kavics, homok-homokkő; 2 - konglomerátum;

3 - homokkő, agyagmárga; 4 - alkáli diabáz termék; 5 - brachiopódás mészkő; 6 - sötét szürke agyagos mészkő; 7 - vastagpados finomkristályos mészkő; 8 - cukorszövetû dolomit; 9 - dolomit márga, márga;

10 - aprógumós mészkő; 11 - iszapmozgásos mészkő; 12 - biogén mészkő; 13 - márga, agyagkő; 14 - mészmárga csíkos mészkő; 15 - dolomit-márga, agyagkő; 16 - vörös és zöld homokkő; 17 - dolomit márga, márga; 18 - vetó

Figure 2 Doline density (LiPPMANN, L. et al. 2008). - 1 - gravel, sand, sandstone; 2 - conglomerata; 3 - sandstone, clay marl; 4 - alcalic-diabase product; 5 - limestone with brachipods; 6 - dark grey argittaceous limestone;

7 - thick-bedded, fine-graimed limestone; 8 - accharoidal dolomite; 9 - dolomite marl, marl; 10 - arenose limestone;

11 - limestone by mud movement; 12 - biogen limestone; 13 - marl, clystone; 14 - calcareous marl lined limestone;

15 - dolomite marl, claystone; 16 - red and green sandstone, aleurit; 17 - dolomite marl, marl; 18 - fault

A hordozó lejtő dőlését tekintve LIPPMANN L. et al. (2008) kimutatta, hogy területüket tekintve a legjelentősebb arányban a 2-7-os lejtőkön fordulnak elő, de a dolinásodási arány a 2-4ำ-os lejtőkön a legnagyobb (a $13^{\circ}$-nál meredekebb lejtőn a dolinák már hiányoznak).

A földtani adatokat tekintve a dolináknak közel a 75\%-a középső triász aprógumós mészkövön alakult ki (LiPPMANN L. et al. 2008).

A relief arány (mélység/átlagos átmérő) a mecseki karszt dolináinak (az adatok $2 \mathrm{db}$ mintaterületről származnak) 30\%-ánál 0,4, 60\%-nál 0,6 és nagyobb, mint az Aggtelekikarszt, vagy a Bükk-hegység dolináinál (KEVEINÉ BÁRÁNY I. et al. 2015). Ez meredekebb oldallejtôt jelent a mecseki karszt dolináinál, ami itt a horizontális oldódás kisebb mértékével magyarázható. De valószínú ennek az is a magyarázata, hogy a feldolgozásba bekerültek utánsüllyedéses dolinák is, amelyek között meredek oldallejtőjüek is előfordulnak. A belső aszimmetria a hosszanti aránnyal, (amely a legmélyebb ponttól számított két hossztengely-részlet hányadosa), a szélességi aránnyal, (amely a legmélyebb ponttól számított két szélességi tengely-részlet hányadosa) és a megnyúlási aránnyal, (amely a teljes hosszúság és teljes szélesség hányadosa) képezhető. Ez a mecseki karszton a legkisebb. KEVEINÉ BÁRÁNY I. et al. (2015) szerint ez arra vezethető vissza, hogy a mecseki karszt dolinái kevésbé szélesedtek, vagy szélesednek, mint az aggteleki, vagy a bükki dolinák. Valószínú, hogy ez esetben is részben az utánsüllyedéses dolinák módosították az adatokat, miután ezek kialakulása és fejlődése kedvez a körkörös formák létrejöttének, illetve növekedésük során ezek megmaradásának. 
A dolinák hosszabbik tengelyei az Abaligeti-karszton a törésvonalakkal (CzIGÁNY Sz.-LOVÁsz Gy. 2006; LIPPMANN L. et al. 2008), míg az Orfúin a völgyek irányával esnek egybe (LIPPMANN L. et al. 2008). Az Orfüi-karszton az utánsüllyedéses dolináké a felszín dőlésirányával amely lehet lokális is (pl.: völgyoldal), mutat egyezést (LiPPMANN L. et al. 2008). Ugyanakkor KEVEINÉ BÁRÁNY I. et al. (2015) vizsgálatai szerint a karszton a dolina hossztengelyek és a szárazvölgyek között a kapcsolat a magyarországi karsztok közül itt a legerősebb. Utóbbi tulajdonságot tekintve hasonló eredményhez jutott VETÉSI-FOITH Sz. et al. (2017) is. KEVEINÉ BÁRÁNY I. et al. (2015) vizsgálatai szerint a dolinák orientációja É-D, illetve a kicsi dolinák (30 m-nél kisebb átmérójúek) NyÉNy-KDK-i irányba mutat maximumot. A legközelebbi szomszéd index értéke azt mutatja, hogy a dolinák mintázata nem mutat szabályszerúséget (KEVEINÉ BÁRÁNY I. et al. 2015).

\section{A karsztformák}

\section{Az oldódásos (drawdown) dolinák}

Az oldódásos dolinák többsége fennsíki helyzetú. A fennsíki helyzet árulkodik arról, hogy nem lehetnek point recharge dolinák, miután ezek völgytalpi helyzetúek. Elkülöníthetôk az utánsüllyedéses dolináktól az alábbiak miatt:

- Az oldódásos dolinák a nagyobb méretúek (3.ábra) mind peremi átmérőjúket, mind mélységüket tekintve. Átmérőjük néhányszor 10 m-nél nagyobb (a 70-80 m-t is elérheti), mélységük a $20 \mathrm{~m}$-t is meghaladhatja. A legnagyobbnak az átmérôje $240 \mathrm{~m}$, mélysége 25-30 m (LovÁsz Gy. 1971). Az utánsüllyedéses dolinák átmérôje 10 m-nél kisebb (mélységük legfeljebb néhány $\mathrm{m}$ ), de többnyire csak 1-3 m (3. ábra).

- Az oldódásos dolinák nem a fedőben (löszben) képződtek, a fedő azokat csak utólag kibélelte, vagy különböző mértékben kitöltötte (4.ábra), míg Ezért a lösz kialakulása előtt jöttek létre. az Az utánsüllyedéses dolinák igen viszont mivel löszbe mélyülnek, annak keletkezését követően. Utóbbiak előfordulhatnak a drawdown dolinákba települt fedőn, vagy a feltöltődött dolinák kitöltésében (4. ábra), vagy dolinamentes fekü fedőjén (5. ábra).

- Az utánsüllyedéses dolinák előfordulása különösen az Orfűi-karszton, egybeesik a drawdown dolinákéval, előzóek egy része oldódásos dolinákban fejlődött ki (3.ábra), így a hordozó dolináknál később alakultak ki.

A kisebb dolinák kétségtelenül fiatalabbak, ahogy azt több szerző is leírja, mint a nagyméretúek (HEvESI A. 2001; LiPPMANN L. et al. 2008). De miután a fedőben alakultak ki eltérő genetikájúak (utánsüllyedéses eredetúek), továbbá fiatalabb karsztosodás eredményeként jöttek létre, mivel közülük sok az oldódásos dolinákat kibélelő, kitöltő, vagy elfedő üledékben képződött.

A drawdown dolinák miután fedővel kibéleltek létrejötte és fejlődése megelőzte a lösz képződést, illetve a fedőben létrejött utánsüllyedéses dolinák kialakulását. A karszt aknafalain a bemosott anyagból számos helyen képződött bevonat, amely csapadékos időszakban az azokat időszakosan elárasztó vízből ülepedett le. A bevonatok fékezik az oldódást. Bár a biogén eredetű $\mathrm{CO}_{2}$ kedvez az oldódásnak, de a bevonatok és a fedőben több helyen jelenlévő mészkőtörmelék az epikarszt oldódásos fejlődését lassítja. Az oldódás nem feltétlenül van hatással az utánsüllyedéses dolinák kialakulására, hisz ekkor csak a fedő szállítódik lokálisan a karsztba.

A drawdown dolinák gyakran megnyúltak és aszimmetrikus keresztmetszetúek a hoszszabbik tengelyük mentén. E dolináknak a dőlésirányba eső lejtőjük a rövidebb és meredekebb. A hosszabbik tengelyük törésekkel (CZIGÁNy Sz.-LovÁsz Gy. 2006), illetve völgyirányokkal (LovÁsz Gy. 1971) és a dolina sorok (ld. alább) irányával esik egybe. 


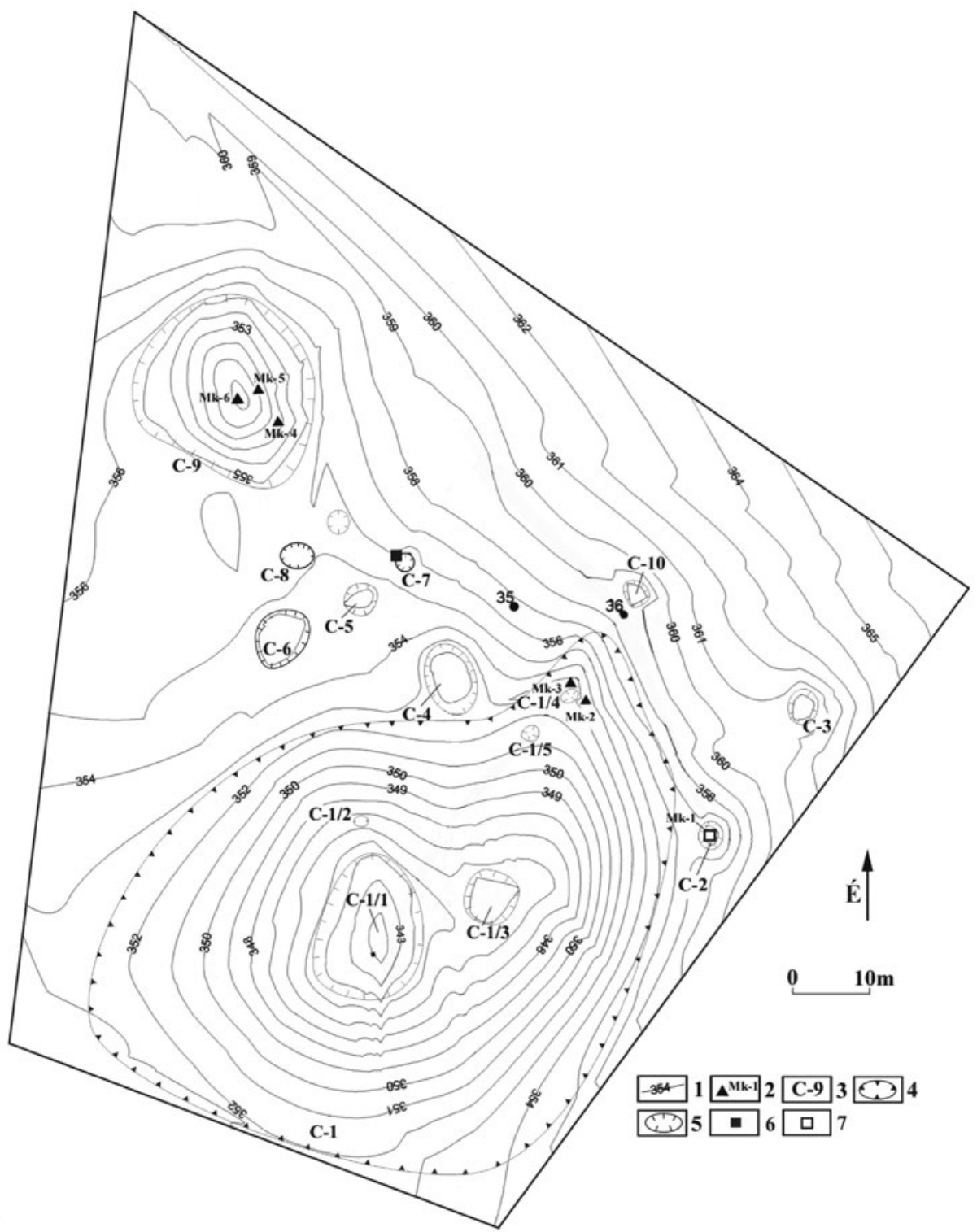

3. ábra Oldódásos és utánsüllyedéses dolinák az Orfúi-karszt Ny-i részéről (Orfüi-karszt, Cigány-hegy, Veres M. 2016)

- 1 - szintvonal; 2 - kőzetkibúvás és azonosító jele; 3 - karsztos mélyedés jele;

4 - oldódásos dolina; 5 - utánsüllyedéses dolina; 6 - járat; 7 - kürtő, akna

Figure 3 Solution dolines and subsidence dolines from the western part of Orfü Karst (Orfü Karst, Cigány Hill, Veres, M. 2016)

-1 - contour line, 2 - rock outcrop and its identification code, 3 - identification mark of karst depression, 4 - solution doline, 5 - subsidence doline, 6 - conduit, 7 - chimney, shaft

Morfológiai környezetük szerint lehetnek tető (magaslat) közeliek, völgyfőiek, valamint völgyközi háton lévők (HEVESI A. 2001). Gyakoriak sík (fennsíki) térszínen, ritkábban előfordulnak még a karszt kisebb völgyeiben (VETÉsi-FoITH Sz. et al. 2017). 


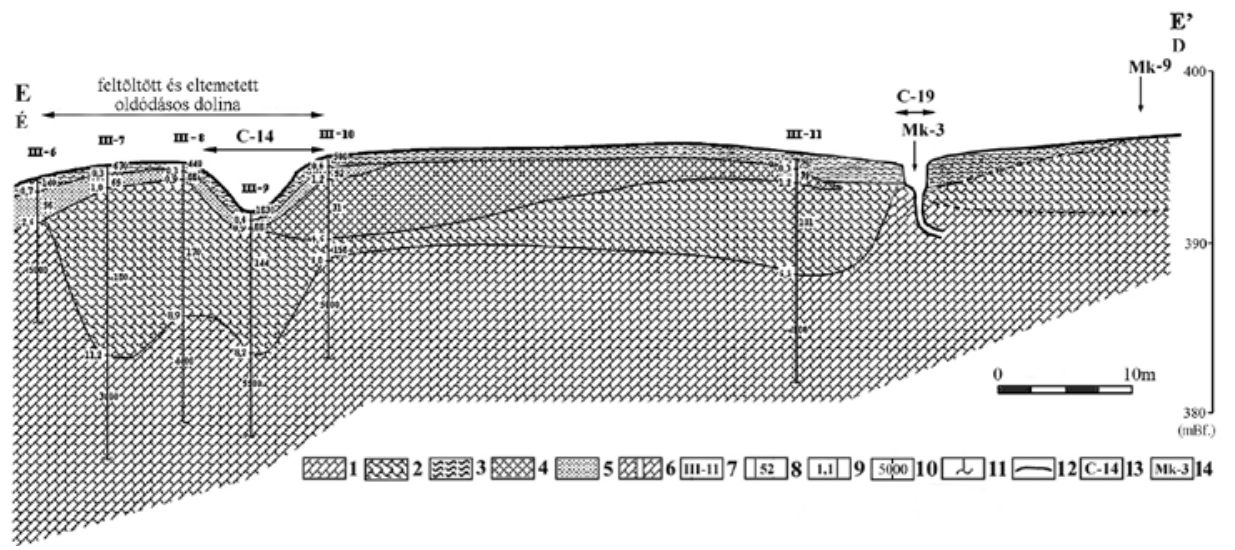

4. ábra Tagolt fekü felett kialakult utánsüllyedéses dolinák geoelektromos-földtani szelvénye az Orfúi-karszton (VERES M. 2016) - 1 - mészkő; 2 - mészkőtörmelék (homok?); 3 - talaj, homok, homokliszt;

4 - agyag (mészkőtörmelék, homokos); 5 - homok, lösz (mészkőtörmelékes); 6 - járat a fedőben és a feküben; 7 - VESZ észlelési hely, azonosító számmal; 8 - összlet geoelektromos ellenállása (Ohm méter);

9 - geoelektromos összlet talpmélysége (m); 10 - a fekü geoelektromos ellenállása (Ohm méter); 11 - VESZ mérés kb.

behatolása; 12 - geoelektromos összlethatár; 13 - karsztos mélyedés jele; 14 - kőzetkibúvás azonosítási jellel

Figure 4 Geoelectric-geological profile of subsidence dolines that developed above dissected bedrock on Orfú Karst (VERES, M. 2016) - 1 - limestone; 2 - limestone debris (sand?); 3 - soil, sand, sand flour;

4 - clay (with limestone debris, sandy); 5 - sand, loess (with limestone debris) 6 - conduit in the cover and in the bedrock; 7 - VES measurement site with identification number; 8 - geoelectric resistivity of series $(\mathrm{Ohmm})$

9 - base depth of the geoelectric series (m); 10 - geoelectric resistivity of bedrock (Ohmm); 11 - approximate depth of penetration of VES measurement; 12 - geoelectric series boundary;

13 - identification code of karst depression; 14 - rock outcrop with identification code

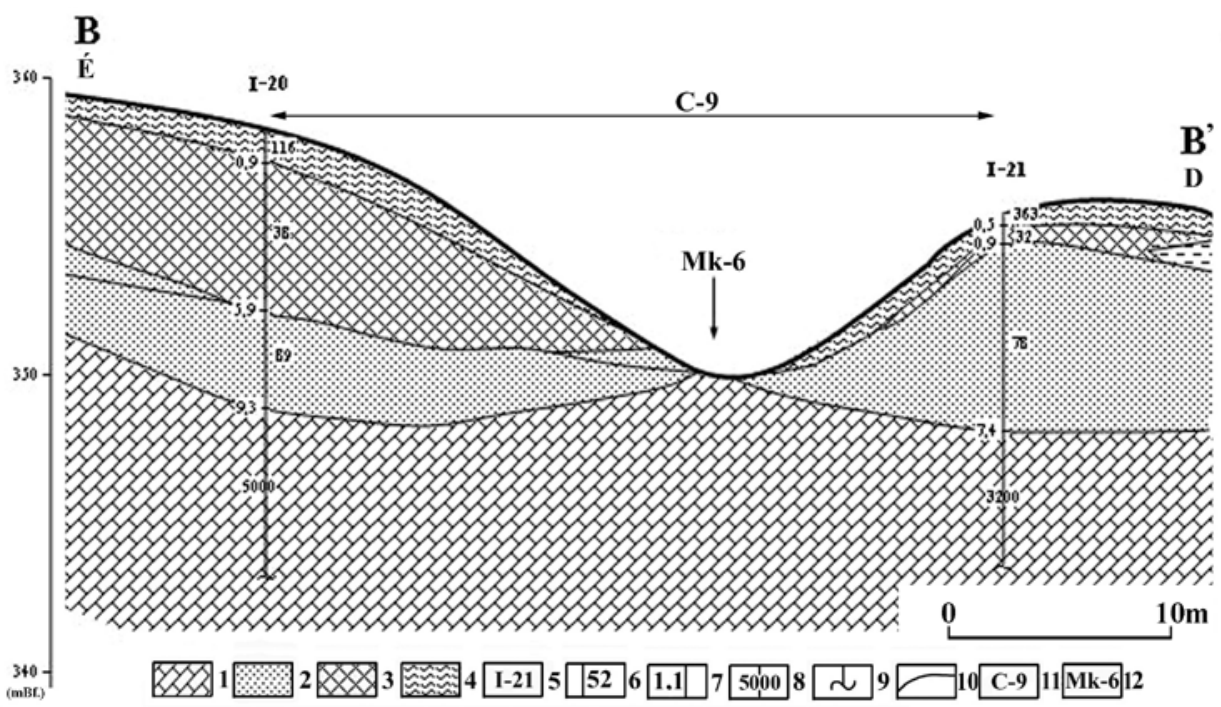

5. ábra Sík fekün kialakult utánsüllyedéses dolina VESZ szelvénye (Orfúi-karszt, Cigány-hegy, Veres M. 2016)

- 1 - mészkó; 2 - homok-lösz (mészkőtörmelékes); 3 - agyag (mészkőtörmelékes, homokos); 4 - talaj, homok, homokliszt; 5 - VESZ mérés helye, azonosítási számmal; 6 - összlet geoelektromos ellenállása (Ohm méter);

7 - geoelektromos összlet talpmélysége $(\mathrm{m}) ; 8$ - a fekü geoelektromos ellenállása (Ohm méter); 9 - VESZ mérés, kb.

behatolása; 10 - geoelektromos összlethatár; 11 - karsztos mélyedés jele; 12 - kôzetkibúvás és azonosító jele

Figure 5 VES profile of subsidence doline that developed on plain bedrock (Orfú Karst, Cigány Hill, VERES, M. 2016) - 1 - limestone; 2 - sand-loess (with limestone debris); 3 - clay (with limestone debris, sandy);

4 - soil, sand, sand flour; 5 - VES measurement site with identification number; 6 - geoelectric resistivity of series $(\mathrm{Ohmm})$; 7 - base depth of the geoelectric series $(\mathrm{m}) ; 8$ - geoelectric resistivity of bedrock (Ohmm);

9 - approximate depth of penetration of VES measurement; 10 - geoelectric series boundary;

11 - identification code of karst depression; 12 - rock outcrop with identification code 
A drawdown dolinák aljzata lehet kissé sík (valószínűleg a részleges feltöltődésük miatt), más dolinák aljzata tölcsérszerúen elkeskenyedő. Belsejükben a talaj és a fedő alól a fekü ritkán és csak kisebb foltokban bukkan elő.

A dolinák lehetnek magányosak (esetleg ikresek), összetettek (HEVESI A. 2001) és csoportosak. Az összetettek talpán időszakos vízhálózat is és vízelvezető hely (utánsüllyedéses dolina) lehet. A csoportos dolinák sorokat alkotnak (LovÁsz GY. 1971, 1977; CzIGÁNY Sz.-LovÁsz Gy. 2006), amelyek változó számú részdolinából álló uvalákra különülhetnek. A dolinasorok íveltek, a sorokban a dolinaszám változó. A dolinasorok elsősorban a völgyek völgyfőinél, illetve azok folytatásában fordulnak elő a sík térszíneken. Különbséget lehet tenni a dolinasor iránya (a sor helyzetét égtájuk adja meg) és irányultsága (az az égtáj, amely irányába a dolinák mérete nő) között. Az irányultság a hordozó térszín dôlésirányával mutat egyezést.

Az Abaligeti-karszton a dolinák 3 dolinasor rendszerbe és néhány dolinasorba rendeződnek. A sorok és rendszerek 350 m alatti magasságú térszínen vannak és É-D-i, vagy ÉNy-DK-i irányúak, irányultságuk É-i, ÉNy-i (LovÁsz Gy. 1971, 1977). A leghosszabb kiterjedése megközelíti a 3 km-t. A rendszerekben a fő dolinasorokhoz mellékdolina sorok (esetenként ezeknek is vannak melléksoraik) kapcsolódnak (LovÁsz Gy. 1971, 6. ábra).

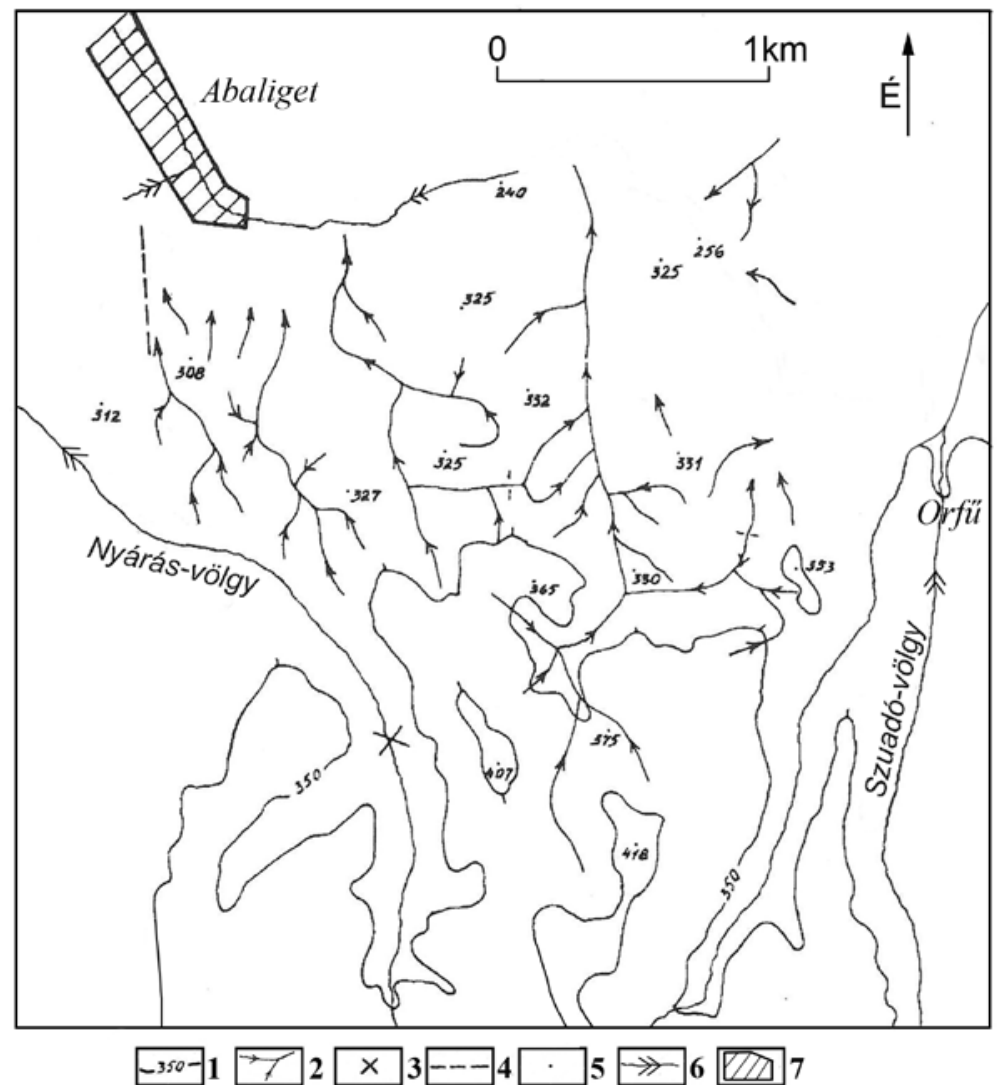

6. ábra Dolinasorok az Abaligeti karszton (LovÁsz Gy. 1977) - 1 - szintvonal; 2 - dolinasor és irányultsága; 3 - víznyelő; 4 - az Abaligeti-barlang; 5 - magaslat; 6 - völgy és vízfolyása; 7 - település

Figure 6 Doline rows on Abaliget Karst (Lovísz, Gy. 1977) - 1 - contour line; 2 - doline row and its orientation; 3 - ponor; 4 - Abaliget Cave; 5 - mound; 6 - valley and its stream, 7 - settlement 
A dolinasoroknak a folytatását képező utánsüllyedéses dolinasorok, a két szintet elválasztó lejtôn is jelen vannak, de az oldódásos dolinák sorai csak az alsó szinten fordulnak elő. (LovÁsz Gy. 1971). Miután a völgyek felé dőlő térszíneken jellegzetesek, feltehetôen a már kialakult völgyhálózathoz igazodik a mintázatuk.

Az Orfűi-karszton, ahol a dolinák négy sorba csoportosulnak (7. ábra) a dolinasorok rövidebbek, mint az Abaligeti-karszton, kevésbé összetettek, változatosabb irányokba esnek, továbbá jelen vannak a két szint közötti lejtőn is (LovÁsz Gy. 1977). Itt gyakoriak a magányos drawdown dolinák. Kevésbé követnek szerkezeti irányokat (LovÁsz Gy. 1977).

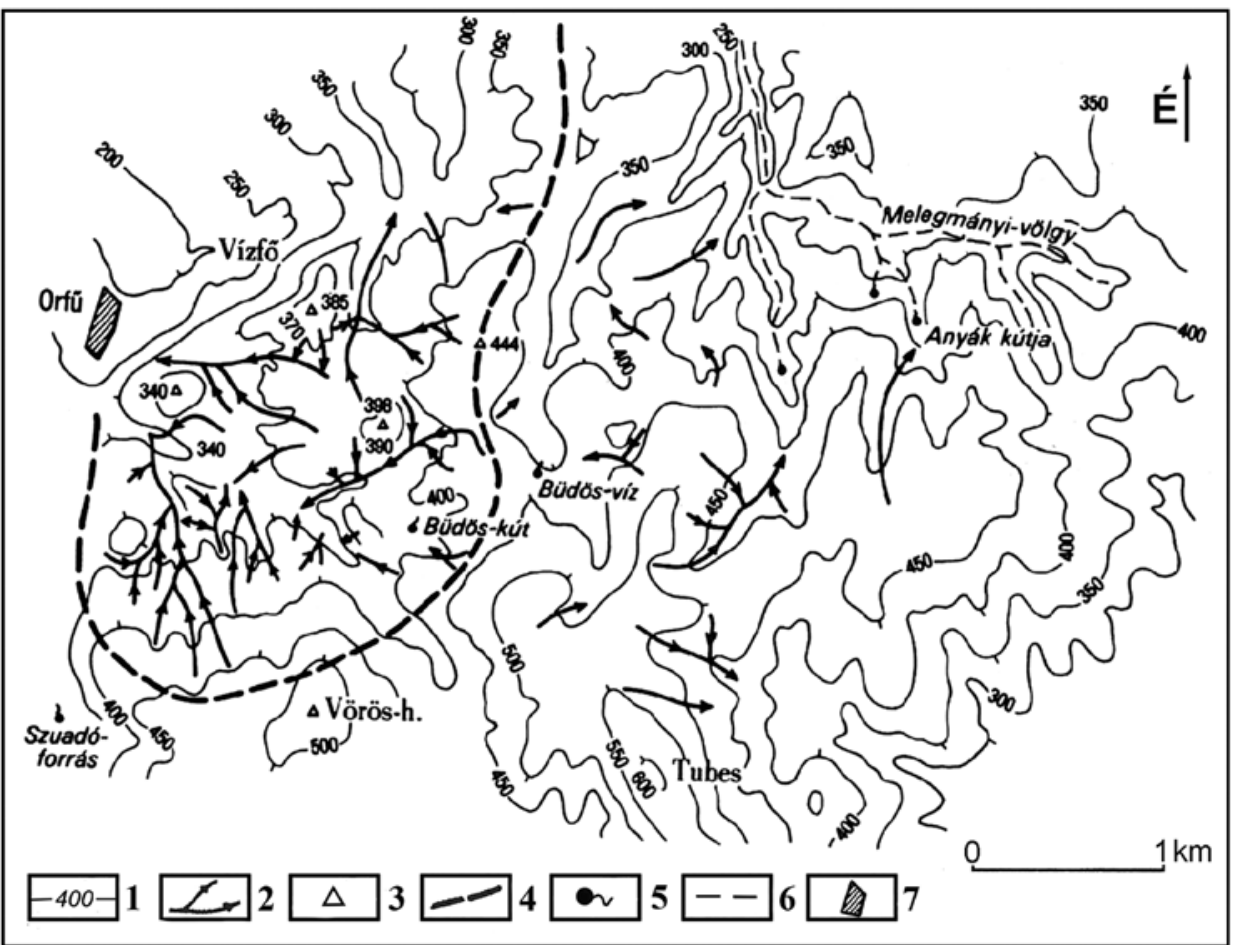

7. ábra Dolinasorok az Orfűi- és a Tubes-Misinai-karszton (LovÁsz Gy. 1977)

- 1 - szintvonal; 2 - dolinasor és irányultsága; 3 - magaslat; 4 - vízválasztó; 5 - forrás; 6 - vízfolyás; 7 - település Figure 7 Doline rows on Orfú Karst and on Misina Tubes Karst (LovÁsZ, Gy. 1977)

- 1 - contour line; 2 - doline row and its orientation; 3 - mound; 4 - watershed; 5 - spring; 6 - stream; 7 - settlement

A Tubes-Misina területén (7. ábra) kevés dolinasor mutatható ki. A sorok még az Orfüi karszt dolinasorainál is kevésbé összetettek. A sorokat részben utánsüllyedéses dolinák alkotják (Lovász Gy. 1977). Tapasztalható (CZIGÁNy Sz.-LovÁsz Gy. 2006), hogy az utánsüllyedéses dolinák az oldódásos dolinasorok mellett fordulnak elő, növelve ezáltal a sorok összetettségét és a dolinasúrúséget. A völgyekkel feltagolt karsztterület részleten a dolinasorok völgyközi hátakon, valamint a nagy völgyek völgyfőiben helyezkednek el (LovÁsz GY. 1977).

A dolinasoroknak, a dolinák morfológiai jellemzőinek és a sorok kifejlődési sajátosságainak a figyelembevételével CZIGÁNY Sz. és LovÁSZ GY. (2006), az alábbi változatait különböztette meg. 
- Rövid (néhány 100 m hosszú) dolinasor, amely uvala, vagy uvalaszerú, miután a dolinák közti válaszfal magassága kisebb, mint a környezetéé. A dolinasor fennsíkon van.

- A dolinasor rövid, és völgy völgyfője felé dőlő lejtőn helyezkedik el. A sor dolinái a völgyfő felé növekednek.

- A dolinasor hosszabb (több dolinából áll), mint a fenti esetekben. Felső (magasabb helyzetû) végük fennsíkon, vagy völgyközi háton van, de a sor alsó vége benyúlik a völgybe és annak talpa felett végződik el. A dolinasornak van mellékága, a fóág dolinái uvalák részei. Irányultságuk többnyire É, illetve ÉNy.

- A dolinasor több km hosszú, amelynek jelentős hosszúságú mellék dolinasorai vannak. É-i irányultságúak, felső végük fennsíkon van, alsó végük völgy pereménél végződik el. A sor egyre alacsonyabb helyzetú dolinái egyre nagyobbak és egyre inkább uvalák részeit képezik.

Valószínú, hogy a völgyeket szegélyező dolinasorok jelenléte és a mellékvölgyek hiánya között kapcsolat van. A dolinasorok dolináit a völgyek felé dőlő felszínen lefolyó és elszivárgó vizek alakítottak ki. A felszíni vizek ugyanakkor elszivárgásuk miatt nem alakíthattak ki mellékvölgyeket.

\section{Utánsüllyedéses dolinák}

E dolinatípus depressziói adják a karszt dolináinak a többségét. Jellemzőik az alábbiak:

- Az utánsüllyedéses dolinák mind az alacsonyabb, mind a magasabb teraszon jelen vannak.

- Méretük, főleg átmérőjűk kicsi,többnyire néhány m (mélységük még ennél is kisebb).

- Uralkodnak a szuffóziósak (oldallejtőjük lankás), de a lezökkenéses dolinák (oldallejtőjük meredek, omlásos) is gyakoriak. Különösen a kisebbek között jellegzetesek az utóbbiak. Valószínú, hogy a dolinák kialakulása a fedő omlásával kezdődik. Az így kialakult kisméretú lezökkenéses dolina (talajos lezökkenéses dolina) lejtői később ellankásodnak és szuffóziósan fejlődik tovább.

- Aljzatuk nem töltődött fel (mindössze egyeseknél a leomlott, lezökkent anyag halma figyelhető meg, de gyakran előbukkan a fekü is). Ez a hordozó térszín kis dőlésével és a vízbevezető formák hiányával (illetve fejletlenségével) magyarázható (a fedő területükról szuffózióval kerül a karsztba). Emiatt hiányozhatnak a feltöltött, inaktív utánsüllyedéses dolinák, amelyek rejtett karsztokon oly gyakoriak.

- Aljzatukon az elvezető járat többnyire hiányzik.

- Morfológiai környezetük szerint előfordulnak sík térszíneken (fennsíkon), völgyközi hátakon, völgyekben, drawdown dolinák soraiban, e dolinákban és környezetében. A völgyi dolinák völgyoldalakban, völgytalpakon és ezek medreiben egyaránt megtalálhatók. A kisebb, részben feltöltött völgyekben uvalaszerúek lehetnek. A drawdown dolinákban a dolinatalpakon a lejtôiken egyaránt jelen lehetnek, de a dolinaperemeken és a szomszédos drawdown dolinák közti válaszfalakon és az uvalak részdolináinak a válaszfalain is megfigyelhetők. Az Abaligeti-karszt É-i peremének meredek oldalában a lezökkenéses dolinák tömegmozgások formáival váltakoznak.

- Mintázatuk szerint előfordulnak egyesével, csoportosan. Utóbbiak szabálytalan csoportokat (halmazokat) képezhetnek, vagy sorokba rendeződhetnek. A drawdown dolinákban egyesével, szabálytalan, vagy soros csoportokban fordulnak elő.

- A nagyobb dőlésú lejtőkön (pl. a völgyoldali helyzetúek) lejtésirányba megnyúltak (LiPPMANN L. et al. 2008). Minél nagyobb a hordozó lejtő dőlése, annál megnyúltabbak (VETÉSI-FOITH Sz. 2017). A megnyúltak alsó, lejtésirányba eső lejtőjük rövidebb és meredekebb, az átellenes hosszabb és kevésbé meredek. 
- A fekü morfológiájához képest a VESZ mérések adatai szerint háromféle helyzetben lehetnek. Így kialakulhatnak sík fekü (5. ábra), feltöltött drawdown dolina (4. ábra) és az elfedett fekü magaslata (4. ábra jobb oldali része) felett. A sík fekü feletti dolinák oldallejtőit kiékelődő fedő rétegek alkotják. A drawdown dolinák kitöltése az utánsüllyedéses dolinák alatt is jelentős lehet, a $10 \mathrm{~m}$ vastagságot is elérheti. Ahol a felső összletek hajlottak, az alsóbb helyzetúek szuffóziós anyagvesztesége okozta a behajlást (4. ábra baloldali része), ahol nem, ott az anyagveszteség omlással a karsztba került (4. ábra jobb oldali része). Valószínúbb, hogy a drawdown dolinák feletti dolinák anyagveszteségéért az olyan epikarsztos járatok a felelősek, amelyek a drawdown dolinák kialakulása során képződtek, míg a sík fekü felettieknél az epikarsztos járatok akár később is létrejöhettek. A drawdown dolinák kitöltésében az utánsüllyedéses dolinák feküjáratainak idősebb voltára (tehát a dolinák posztgenetikusak) utal, hogy alattuk a dolinakitöltés mészkőtörmelék (4. ábra) vagy mészkőtörmelékes. Miután a fedő megközelíti a 10 m-t (sőt meg is haladja) a beszivárgó víz a feküre valószínúleg telítetten érkezik és így a fekün az oldódás a fedô és így az utánsüllyedéses dolina kialakulása előtt történt.

- A dolinák kialakulási helye kapcsolatot mutat az agyag, vagy agyagos összletek jelenlétével. Elsősorban ott alakulnak ki az utánsüllyedéses dolinák, ahol az agyag betelepülés kiékelődik és így folytonossága megszakad (4. ábra). Itt a szuffóziót és így a dolina kialakulását elősegíti az agyagot elérő, majd felette szivárgó víz. Ugyanis az agyag kiékelődésénél összegyúlô és így több víz, lefelé szivároghat, erôsítve a szuffóziót. Előfordulhat, hogy az agyag összlet is hajlott, amely hordozza az utánsüllyedéses dolinát. Ekkor az agyag alatti fedőből távozott el az anyag a karsztba. Ez úgy lehetséges, hogy az agyag alá beszivárgó csapadékvíz (amely drawdown dolina legmélyebb pontjáig jut), okozza a szuffóziót.

Az a tény, hogy a karszton az utánsüllyedéses dolinák száma nagy, feltehetôen több, a kialakulásukat indukáló ok meglétével magyarázható. Ezek az alábbiak.

- A karszt különösen az alacsonyabb É-i rész magassága folytán kedvezett a löszképződésének.

- A lösz mészmentessége (Hevesi A. 2001) kedvez az epikarsztos járatok jelenlegi (illetve közelmúltbeli létrejöttének) és így szingenetikus utánsüllyedéses dolinák kialakulásának, mert ez nem csökkenti a felülről érkező szénsavas víz oldóképességét (bár a VESZ mérések szerint több helyen is a fedő mészkőtörmelékes).

- A fedő kis vastagsága (bár a drawdown dolinákban az utánsüllyedéses dolinák alatt a fedő vastagsága gyakran meghaladja a depressziók közti térszínekre az irodalomban megadott értékeket, az a 10 m-t nem, vagy alig haladja meg).

- A már említett agyagos, de kiékelődő betelepülések, amelyek a koncentrált vízbevezetésnek kedveznek a karsztba.

- A hordozó felszín kicsi tagoltsága, amely kedvez a beszivárgásnak és a lösz megmaradásának, valamint egységes kifejlődésének. A kicsi beszivárgást hátráltató szerepét bizonyítja, hogy a Misina-Tubes karsztján, ahol több a völgy és így a karsztból több víz folyhat ki a felszínen, kevesebb a dolina. De az is, hogy a mellékvölgy nélküli völgyhátakon, tehát a beszivárgásra alkalmasabb térszíneken, nagyobb a dolinasűrúség.

- A hordozó felszín kicsi dőlése, amely ugyancsak kedvez a beszivárgásnak.

- A drawdown dolinák jelenléte, amelyek nem csak üledék-, hanem csapadékvíz csapdaként is múködnek.

- Az idősebb karsztosodás során kialakult epikarszt. (Az idősebb karsztosodás során kialakult epikarsztos járatokhoz kapcsolódóan posztgenetikus utánsüllyedéses dolinák képződnek.) 


\section{Viznyelók}

Víznyelők sorakoznak a karszt abaligeti és orfúi részének déli pereménél, ahol a jól karsztosodó kőzetek nem karsztos, illetve rosszul karsztosodó kőzetekkel érintkeznek, többnyire az átmenő völgyek talpain. A depressziókhoz állandó vizú vízfolyások (Szuadóvölgy, Nyárás-völgy patakja), illetve időszakos vízfolyások (Büdös-kúti-völgy) vezetnek (BARTA K.-TARNAi T. 1997).

Bár a magyar karsztos irodalomban, ahogy fentebb is említettük, e formákat víznyelőként tartják számon valószínúbb, hogy ezek point recharge dolinák. Ezt támasztják alá az alábbiak:

- Egyesek közülük nem kőzethatárnál, hanem a karszt belsejében vannak (Nyárásvölgy, Büdöskúti-völgy víznyelői), mások kőzethatáron ugyan, de dolomit és mészkô érintkezésénél.

- Ugyanazon völgy talpán sort alkotnak (Szuadó-völgy, Büdöskúti-völgy víznyelői).

- Nincs minden esetben a depresszióknál a völgytalpon ellenesésú rész, tehát vakvölgy. Ennek hiányában áradáskor a víz átfolyik a felsőbb helyzetû depressziókon és az alsóbb helyzetúekbe áramlik, mint azt a Szuadó-völgy depresszióinál megfigyelték (BARTA K.-TARNAI T. 1997).

A karszt víznyelői, vagy víznyelőként múködő képződményei az alábbiak (BARTA K.-TARNAI T. 1997): A Vízfő-forrás vízgyújtőjéről a Büdöskúti-völgyben kettő, majd a Remeteréti-völggyel egyesülő szakaszán még további kettő képződmény. A Szuadóvölgyben három (Szuadó-, Gilisztás-, Trió-víznyelő) víznyelőként múködő képződmény van. A Körtvélyesi-völgyben csak vízelszivárgás van (BARTA K.-TARNAI T. 1997). Az Abaligeti-barlang vízgyújtőjén a Nyárás-völgy és a Vigánvári-völgy víznyelője említhető. E képződmények, mint említettük, a karsztra átnyúló (azon áthaladó) völgyek talpán helyezkednek el.

\section{Kiválások}

KRAFT J. et al. (1986) a Mecsek-hegységben 13 db mésztufa előfordulást (8. ábra) írt le (közülük karsztvízből azonban csak 9 db származik), amelyek képződési kora fiatal (holocén). Keletkezésük 2500-5000 év között volt a legintenzívebb (KRAFT J. et al. 1986). Legjelentősebb a Tettye-forrás mésztufája, ahol az mintegy 300 m hosszan halmozódott fel. Itt fenti szerzők szerint a mésztufa képződése idősebb, valószínúleg már az alsó-pleisztocénben elkezdődött. Tanulmányukban megkülönböztettek völgytalpon (mederben) és völgyoldalban (lejtőn) képződött mésztufákat. Az előfordulásokból 6 db völgytalpi, 7 db lejtői helyzetû (azonban a Tettye-forrás édesvízi mészkövének van lejtői környezetû része is). Közülük 3 db mésztufakúpos, 10 db medencés gátas kifejlődésú, de kettőnél mikrogátak is előfordulnak (1. táblázat).

\section{Következtetések}

A Nyugat-Mecsek karsztja abráziós teraszokon fejlődött ki, formakincsét oldódásos dolinák és utánsüllyedéses dolinák adják. A karszt dolinasûrűsége nagy (a legnagyobb a magyarországi karsztokat tekintve). Az oldódásos dolinák dolinasorokat, valamint fóés mellék dolinasorokból álló dolinarendszereket alkotnak. Irányultságuk megegyezik a felszín dőlésirányával. A dolinasorok völgyek folytatásában, a völgyeket övező és ezek felé dőlő felszíneken fordulnak elő. Az utánsüllyedéses dolinák gyakran az oldódásos dolinák talpán fejlődtek ki. Az oldódásos dolinák egy idősebb, míg az utánsüllyedéses dolinák egy fiatalabb karsztosodás során jöttek létre. 


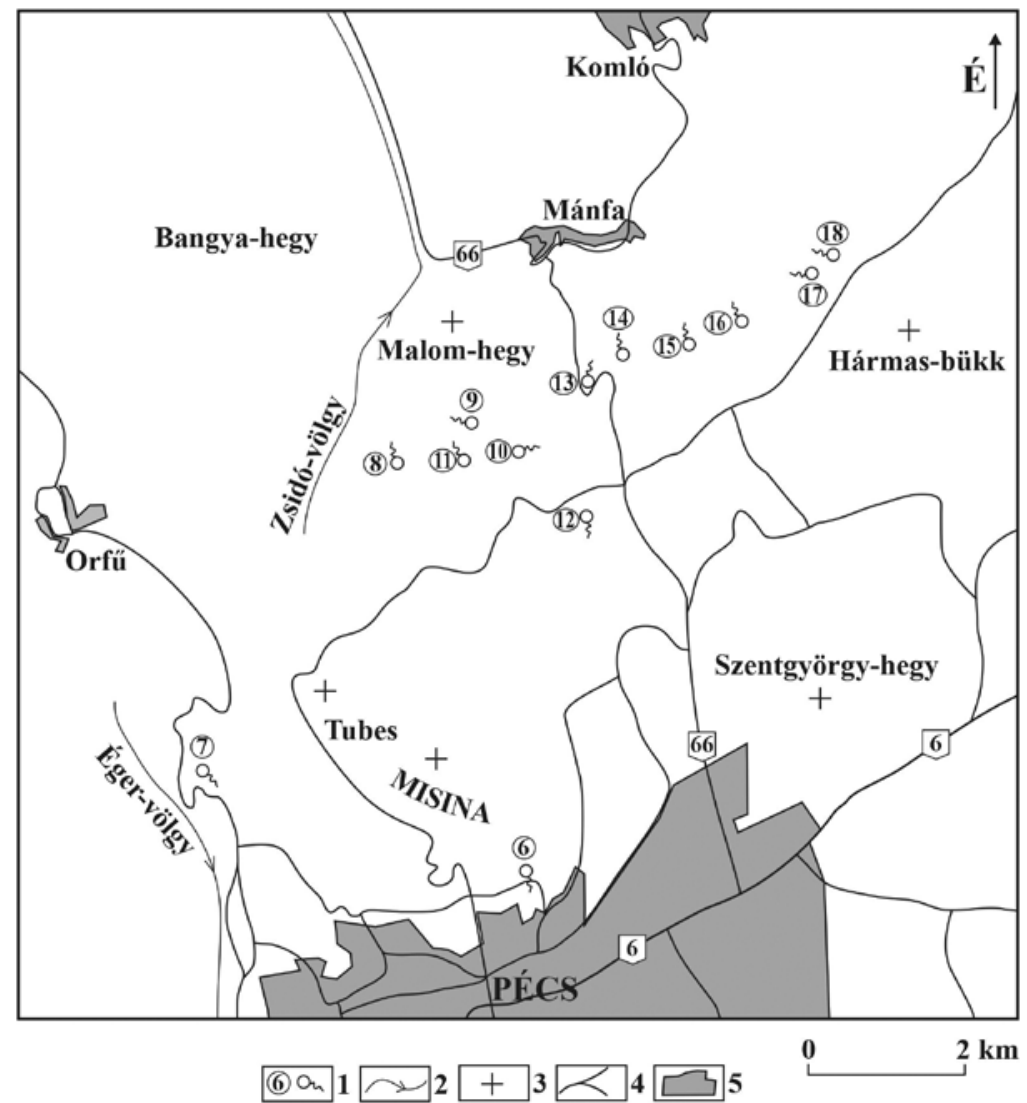

8. ábra Édesvízi mészkő előfordulások a Mecsek-hegységben (KRAFT J. et al. 1986) módosított -1-forrás; 2-vízfolyás; 3-hegy; 4-út; 5-település. Megjegyzés: az előfordulások megnevezései az 1. táblázatban láthatók Figure 8 Calcareous sinter occurrences in the Mecsek Mountains (KRAFT, J. et al. 1986, modified)

1 - spring; 2 - stream; 3 - mountain; 4 -road; 5 - settlement. Notice: names of occurrences are in Table 1

A mecseki édesvízi mészkövek néhány jellemzője

1. táblázat - Table 1

(KRAFT J. et al. 1986 adatainak felhasználásával)

Some characteristics of the freshwater limestones of the Mecsek Mountains (based on the data of KRAFT, J. et al 1986)

\begin{tabular}{|c|c|c|c|c|c|}
\hline Előfordulási hely & $\begin{array}{l}\text { jele a } \\
\text { 8. ábrán }\end{array}$ & $\begin{array}{l}\text { tsz.f.m. } \\
\text { (m) }\end{array}$ & víztípus & $\begin{array}{l}\text { lerakódási } \\
\text { környezet }\end{array}$ & morfológiája \\
\hline Tettye & 6 & 233 & primér karsztvíz & völgytalpi ${ }^{1}$ & medencés gát \\
\hline Kancsal-forrás & 7 & 260 & résvíz & lejtői & mésztufakúp \\
\hline Kánya-forrás & 8 & 305 & primér karsztvíz & völgytalpi & medencés gát \\
\hline Barátság-forrás & 9 & 290 & primér karsztvíz & lejtői & mésztufa kúp \\
\hline Dagonyázó-forrás & 10 & 322 & primér karsztvíz & völgytalpi & medencés gát \\
\hline Anyák-kútja & 11 & 320 & primér karsztvíz & völgytalpi & medencés gát \\
\hline Zsolnay-kút & 12 & 351 & résvíz & lejtői & medencés gát \\
\hline
\end{tabular}




\begin{tabular}{lccllll}
\hline Elöfordulási hely & $\begin{array}{c}\text { jele a } \\
\text { 8.ábrán }\end{array}$ & $\begin{array}{c}\text { tsz.f.m. } \\
(\mathbf{m})\end{array}$ & \multicolumn{1}{c}{ víztípus } & $\begin{array}{l}\text { lerakódási } \\
\text { környezet }\end{array}$ & morfológiája \\
\hline $\begin{array}{l}\text { Körtvélyesi-forrás } \\
\text { Alsó-Körtvélye- }\end{array}$ & 13 & 310 & primér karsztvíz & lejtői & mésztufa kúp \\
si-forrás & 14 & 300 & karsztvíz & völgytalpi & medencés gát \\
Szárazgödör & 15 & 300 & karsztvíz & völgytalpi & medencés gát \\
Nagy-forrás & 16 & 300 & karsztvíz & völgytalpi & medencés gát \\
Bugyogó-forrás & 17 & 318 & résvíz & lejtői & medencés gát \\
Kószegi-forrás & 18 & 318 & résvíz & lejtói & medencés gát \\
\hline
\end{tabular}

1 = felső része lejtői

Az oldódásos dolinák fejlődésében itt kisebb a szerepe a horizontális oldódásnak, mint az Aggteleki-karszton, vagy a Bükk-hegységben.

Az utánsüllyedéses dolinák nagy sûrû́ségéhez több tényező is hozzájárult. Így a felszín kicsi dőlése, kicsi tagoltsága, a lösz jelenléte és egységes kifejlődése, a víz csapdaként múködő oldódásos dolinák jelenléte, a mésztartalom hiánya a fedőben, a fedő kicsi vastagsága, abban az agyagos betelepülések és valószínúleg az idős epikarsztos járatok elterjedtsége.

\section{Köszönetnyilvánítás}

A szerző köszönetet mond a Terratest Kft. munkatársainak a VESZ mérések kivitelezéséért, valamint a geoelektromos-földtani szelvények elkészítéséért.

\section{Veress Márton}

ELTE SEK Földrajz Tanszék, Szombathely

veress.marton@sek.elte.hu

\section{IRODALOM}

BARTA K.-TARnAi T. 1997: Karsztkutatás az orfúi Vízfő-forrás vízgyújtő területén. - Karszt és Barlang I-II. pp. 12-19.

CzIGÁny Sz.-LovÁsz Gy. 2006: A mecseki karszt térképezésének újabb eredményei. - Pécsi Egyetem, Pécs 28. pp. 3-14.

DövÉNYI, Z. (2010): Dunántúli-dombság. - In: DöVÉNYI, Z. ed., Magyarország kistájainak katasztere. Magyar Tudományos Akadémia Földrajztudományi Kutatóintézet, Budapest pp. 431-530.

ForD, D.C.-Williams, P.W. 2007: Karst Hydrogeology and Geomorphology. - John Wiley \& Sons, Ltd., Chichester $562 \mathrm{p}$.

HAAs J. 1994: Magyarország földtana, Mezozoikum. - ELTE, Budapest, pp. 85-91.

HEvesi A. 1991: Magyarország karsztvidékeinek kialakulása és formakincse, II. rész. - Földrajzi Közlemények CXV (3-4). pp. 99-120.

Hevesi A. 2001: A Nyugat-Mecsek felszíni karsztosodásának kérdései. - Karsztfejlődés VI. pp. 103-111.

Hоүк E. 2002: A Nyugat-Mecsek karszt dolináinak morfometriai vizsgálata. - Karsztfejlődés VII. pp. 161-171.

JAKUCS L. 1977: A magyarországi karsztok fejlődéstörténeti típusai. - Karszt és Barlang I-II. pp. 1-16.

JAKUCS L: 1980: A karszt biológiai produktum. Földrajzi Közlemények 104(4) pp. 331-344.

JAKUCs L.-KEvEINÉ BÁRÁNY I.-MEzősi G. 1983: A karsztkorrózió korszerú értelmezése. - Földrajzi Közlemények 107(3-4) pp. 207-218.

KEVEINÉ BÁRÁNY I.-KISS M.-SimON N. 2015: Néhány további adat a hazai karszt dolinák aszimmetriájának kialakulásához. - Karsztfejlődés XX. pp. 125-144. DOI:17701/15.125-144 
Koltai G.-Kele S.-KÁRMÁN K.-Keveiné BÁRÁNy I. 2012: Édesvízi mészkövet lerakó források geokémiai vizsgálata a Mecsekben. - Karsztfejlődés XVII. pp. 35-46.

Kraft J.-Scheuer Gy.-Schweitzer F. 1986: A Pécs-környéki forráslerakódások vizsgálata. - Pécsi Múszaki Szemle XXXI.(3). pp. 13-18.

LipPMAnN L.-Kiss K.-MóGA J. 2008: Az Abaliget-Orfúi karszt karsztos felszínformáinak vizsgálata térinformatikai módszerekkel. - Karsztfejlődés XIII. pp. 151-166.

LovÁsz Gy. 1971: Adatok az Abaligeti-karszt geomorfológiai és hidrológiai jellemzéséhez. - Földrajzi Értesítő XX(3). pp. 283-296.

LovÁsz Gy. 1977: Geomorfológia: Kőzetek. - In: LovÁsz Gy. (ed): Baranya megye természeti földrajza, Baranya Megyei Levéltár, Pécs, pp. 62-68.

LovÁsz Gy. 1981: A Baranyai-dombság, a Mecsek és a Villányi-hegység. - In: PÉcsi M. (szerk.): A Dunántúlidombság (Dél-Dunántúl), Akadémia kiadó, Budapest pp. 124-136.

Sauro, U. 2012: Closed Depressions in Karst Areas. - In: White, W.B.-Culver, D.C. (szerk.), Encyclopedia of Caves, Elsevier, Amsterdam, 140-155.

SzABó P. Z. 1968: A magyarországi karsztosodás fejlődéstörténeti vázlata. - Dunántúli Tud. Gyűjtemény: pp. $13-25$.

TELBISZ T. 2001: Új megközelítések a töbör-morfológiában az Aggteleki-karszt példáján. - Földrajzi Közlemények CXXV(1-2). pp. 85-108.

VERESS M. 2011: Adatok a Mecsek-hegység fedett karsztosodásához a Cigány földi mintaterületről vett példák felhasználásával. - Karszt és Barlang, 2010 évf. I-II. pp. 9-30.

VERESS, M. 2016: Covered Karst. - Springer, Berlin, Heidelberg, New York 536 p. DOI 10.1007/978-94-017-7518-2

VERESS M. 2018: Karsztos mélyedéstípusok és elkülönítésük szempontjai. - Földrajzi Közlemények 142(1) pp. 3-20.

VETÉSI-FoITH Sz.-KISS Z.-GÁRDONYI I. 2017: A Mecseki karszt oldódásos- és utánsüllyedéses töbreinek morfometriai elemzése. - Karsztfejődés, XXII. pp. 119-138.

Williams, P. W. 1985: Subcutaneous hydrology and the development of doline and cockpit karst. Zeits. f. Geomorphology, 29(4): 463-482.

Williams, P.W. 2004: Dolines. - In: GunN J (ed.), Encyclopedia of Caves and Karst Science, Fitzroy Dearborn, New York, London, pp. 304-310. 


\title{
NYITNI VAGY NEM NYITNI? - PILISI BARLANGOK SZELLŐZÖTTSÉGE A GEOKÉMIAI ADATOK TÜKRÉBEN
}

\author{
DEMÉNY ATTILA - BERENTÉS ÁGNES - CZUPPON GYÖRGY \\ - KOVÁCS RICHÁRD - LEÉL-ÔSSY SZABOLCS - SURÁNYI GERGELY \\ TO OPEN OR NOT TO OPEN? VENTILATION \\ IN THE PILIS CAVES IN THE LIGHT OF GEOCHEMICAL DATA
}

\begin{abstract}
Speleothem formations are one of the most important and informative objects in paleoclimatological research. However, in order to interpret the data that reflect environmental conditions, we have to know the operation of the given cave, and it should be determined how the composition of the carbonate formed at the given site is related to the changes in the environmental parameters. The study presents the results of stable isotope geochemical analysis of speleothem formations and carbonate precipitated on glass plates collected in the Vacska Cave (Pilis Hills). The youngest layer of carbonate formations, formed in the last 1-2 decades, shows an isotope fractionation sign indicating strong ventilation, with the exception of a single site farthest from the entrance to the cave. The isotope shift was also accompanied by a change in carbonate fabric. Preceding the fabric change, the carbonate of the speleothem formations did not show ventilation-related shifts in the isotope compositions, suggesting that the exploration and opening of the cave areas may have caused the change. Based on this, we recommend the installation of local closures in the Vacska Cave and in the entire Ariadne cave system. The study provides a good example of how the results of basic research can be utilized in practical environmental protection, in the preservation of a strictly protected cave environment.
\end{abstract}

Keywords: Pilis caves, speleothems, stable isotope geochemistry, ventilation, environmental protection

\section{Bevezetés}

A barlangi karbonátképződmények (cseppkövek és lefolyások) kutatása a múltbeli éghajlati és környezeti viszonyok megállapítására jelentős múltra tekint vissza, a SCOPUS adatbázis csaknem 3700 publikációt tart nyilván a „speleothem or stalagmite” keresés alapján. A képződmények előnye, hogy viszonylag pontosan meg lehet határozni a korukat és hogy változatos adathalmazt lehet belőlük kinyerni, ami a klímára és környezeti feltételekre utaló információt hordoz, és amiket proxiknak nevezünk. A két legfontosabb proxifajta a stabilizotóp-összetétel (a szén és az oxigén stabilis izotópjainak aránya, ${ }^{13} \mathrm{C} /{ }^{12} \mathrm{C}$ és ${ }^{18} \mathrm{O} /{ }^{16} \mathrm{O}$ ), illetve a karbonátba zárt nyomelemek (pl. Mg, $\mathrm{P}, \mathrm{Sr}, \mathrm{U}$, stb.) koncentrációja. Az érdeklődők kiváló összefoglalást találnak FAIRCHILD és BAKER 2012-ben megjelent könyvében. Általános szabályként kijelenthető, hogy a hazai barlangok cseppköveiben a ${ }^{12} \mathrm{C}$ és a ${ }^{16} \mathrm{O}$ izotópok dúsulása, a foszfor mennyiségének növekedése, és a stroncium és magnézium mennyiségének csökkenése csapadékos és meleg klímaviszonyokra utal, az ellenkező változások pedig szárazabb és hidegebb klímát jeleznek (DEMÉNY et al. 2017a,b; DEMÉNY et al. 2019a; KERN et al. 2019). Ugyanakkor az is általános megfigyelés, hogy ezeket a proxikat a felszínen jellemző klíma- és környezeti feltételek mellett az adott barlangra jellemző lokális folyamatok is jelentősen befolyásolják, esetenként teljesen elfedve a nagyobb régióra jellemző klímajelet. Éppen ezért elsődleges feladat a barlang múködésének megértése, annak megállapítása, hogy a karbonátokból kinyert proxi adatok hogyan tükrözik 
a környezeti paramétereket. Ezt leggyakrabban monitoringgal, a barlangi környezet fizikokémiai paramétereinek több éven át tartó felvételezésével, és a karbonátképződés mechanizmusának elemzésével tudjuk elérni. A fontosabb vizsgált fizikokémiai paraméterek a barlangi levegő hőmérséklete és $\mathrm{CO}_{2}$-tartalma, a csepegővíz pH-értéke, stabilizotópos és kémiai összetétele, valamint ezek szezonális változásának elemzése.

Mindemellett fontos szempont a barlangok viselkedésének megértésében, hogy a monitoring leggyakrabban néhány éven keresztül tart, általában egy 4-5 éves projekt első néhány évét jelenti, az évtizedes hosszúságú monitoring munka ritka. Ebből következően a hosszabb távú változásokat ez a tevékenység nem tudja feltárni és az adatokat csak rövid időszakot lefedő meteorológiai adatbázissal lehet összehasonlítani. Ennek áthidalására érdemes a gyưjjtéskor is aktívan képződő, és lehetőség szerint ismert képződési idejü (pl. ismert időpontú barlangi feltárás által létrehozott felületen növekvő) cseppköveket gyújteni (amennyiben lehetséges), illetve lefolyásokat, karbonátos bekérgezéseket magfúrással mintázni. Erre mutatott példát DEMÉNY et al. (2017c) tanulmánya, amiben négy fiatal cseppkövet vizsgáltak a Baradla-barlangból. A vizsgált cseppkövek két helyszínről származtak, gyorsabb és lassabb képződési sebességű is volt köztük, amit későbbi tanulmányok is tudtak hasznosítani (pl. DEMÉNY et al. 2021). 2018-ban újabb kutatás indult a pilishegységi Ariadne-barlangrendszer cseppköveinek vizsgálatára, aminek része volt a barlangi monitoring is. Ennek eredményeit egy megjelenés előtt álló könyvfejezet foglalja össze (CZUPPON et al. 2021). A kutatási tevékenység során a monitoring mellett aktív, kisméretû cseppköveket, valamint lefolyásokból vett magmintákat gyújtöttünk. A kutatás egyik fő kérdése az volt, hogy a jelen monitoring eredményeit mennyiben lehet alkalmazni a cseppkövekben rögzített proxi adatsorok paleoklimatológiai értelmezésében. A vizsgálatok során jelentős változásokat figyeltünk meg a cseppkövek és lefolyások legfiatalabb rétegében, aminek értelmezését és ennek alapján a barlangi környezet védelmére tett javaslatot tartalmazza a jelen munka.

\section{Tudományos háttér}

A paleoklimatológiai kutatás céljára olyan cseppköveket keresünk, amelyek egyrészt elegendően nagy koncentrációban tartalmaznak uránt és elenyésző bennük a detritális anyaggal behordott tórium (lásd még SiKLÓsy et al. 2011-es cikkét), ami lehetővé teszi a pontos korhatározást, másrészt egyensúlyi körülmények között kivált kalcitból állnak. Az egyensúlyi körülmény ebben az esetben azt jelenti, hogy a csepegővíz és a kiváló karbonát között dinamikus egyensúly állt fenn, a karbonát elegendően gyorsan vált ki, hogy észlelhetó és mintázható éves laminákat tartalmazzon, de elég lassan, hogy az oldattal kialakuljon a dinamikus egyensúly. Ennek ellentéte a kinetikus frakcionációval érintett karbonátkiválás, amikor a kiváláskor nem áll fenn dinamikus egyensúly és nem a felszíni környezeti körülményekre utaló vízösszetételek, hanem a kiválás helyére jellemző folyamatok dominálnak a proxiösszetételek kialakulásában. Ilyen helyi folyamat a szellőzöttség miatti erős kigázosodás. Amint a csepegővíz megérkezik a cseppkő felszínére, a szén-dioxid egy része eltávozik, a karbonát oldhatósága lecsökken, és kiválik a karbonát. Ha ez erős szellőzöttség mellett megy végbe, akkor a $\mathrm{CO}_{2}$ kigázosodása és eltávozása gyors, nem áll be az egyensúly. A gyors gázeltávozás miatt a gyorsabban mozgó könnyú izotópban $\left({ }^{12} \mathrm{C}\right.$ és $\left.{ }^{16} \mathrm{O}\right)$ dús molekulák távoznak el, a maradék oldat feldúsul a nehéz izotópokban $\left({ }^{13} \mathrm{C}\right.$ és $\left.{ }^{18} \mathrm{O}\right)$ és a kiváló karbonátban együttes ${ }^{13} \mathrm{C}$ - és ${ }^{18} \mathrm{O}$-dúsulás jelenik meg. Technikai okokból a stabilizotóp-geokémiában nem abszolút izotópkoncentrációkkal vagy izotóparányokkal, hanem nemzetközi sztenderdekhez viszonyított delta értékekkel dolgozunk: 
és

$$
\delta^{13} C=\left[\frac{\left(\frac{{ }^{13} C}{{ }^{12} C}\right)_{\text {minta }}}{\left(\frac{{ }^{13} C}{{ }^{12} C}\right)_{\text {sztenderd }}}-1\right] \times 1000
$$

$$
\delta^{18} O=\left[\frac{\left(\frac{{ }^{18} O}{{ }^{16} O}\right)_{\text {minta }}}{\left(\frac{{ }^{18} O}{{ }^{16} O}\right)_{\text {sztenderd }}}-1\right] \times 1000
$$

A sztenderd a karbonátok esetében a V-PDB, a $\delta^{13} \mathrm{C}$ és $\delta^{18} \mathrm{O}$ értékek dimenziója az 1000-rel történő szorzásra utalóan \%o (tehát nem koncentráció, nem a \% tizedrésze). A stabilizotóp-mérések a Csillagászati és Földtudományi Kutatóközpont Földtani és Geokémiai Intézetében készültek, a méréstechnikáról további részletek DEMÉNY et al. (2019b) tanulmányában olvashatóak.

Mindebből következően ha a cseppkőben erôs pozitív $\delta^{13} \mathrm{C}-\delta^{18} \mathrm{O}$ korrelációt látunk, akkor gyanakodhatunk, hogy az adatok nem a felszíni környezeti körülményeket, hanem a barlang helyi sajátosságait tükrözik. Ugyanakkor ez csak gyanú, mivel megfelelő környezeti körülmények szintén okozhatnak a cseppkőben pozitív $\delta^{13} \mathrm{C}-\delta^{18} \mathrm{O}$ korrelációt. Például a száraz és meleg klíma esetén a barlang fölötti talaj biológiai aktivitása csökken, kevesebb ${ }^{12} \mathrm{C}$-dús biológiai eredetű $\mathrm{CO}_{2}$ oldódik be, és a delta érték egyenletéból következően ez pozitív $\delta^{13} \mathrm{C}$-eltolódást eredményez. A meleg klímához a csapadékvízben ${ }^{18} \mathrm{O}$-dúsulás járul, ami megjelenik a csepegővízben és a belőle kiváló cseppkő összetételében is. Ezekre a problémákra adott megoldást DoRALE és LiU (2009) tanulmánya, akik a geokémiai proxi rekordok reprodukálhatóságának vizsgálatát javasolták. Amennyiben több, független rekord (adatsor) is ugyanazt a változást mutatja, a rekordok környezeti proxiként foghatóak fel, míg a nem reprodukálható adatsor valószínúleg helyi folyamatokat tükröz. A következő kérdés az, hogy a helyi folyamatok feltárására végzett monitoring eredményei mennyire függnek az antropogén hatásoktól és a barlangok jelenlegi állapota visszavetíthető-e a múltra?

\section{Módszertani háttér - A vizsgált cseppkövek és egyéb minták}

A jelen tanulmányban a pilis-hegységi Vacska-barlangra koncentráltunk. A barlangi kutatási engedélyt a Komárom-Esztergom Megyei Kormányhivatal biztosította. A barlangon belül több helyszínrôl tudtunk cseppkövet és cseppkőlefolyásokból fúrómagot gyújteni, valamint egy helyszínen üveglemezeket helyeztünk a csepegési pontok alá. A MakacsMacska teremből (1.ábra) sikerült gyújteni egy kb. $3 \mathrm{~cm}$ magas, aktívan képződő cseppkövet (Vacska-1, 2.A ábra), amit elvágva tiszta kalcit rétegek tárultak fel néhány hiátussal (a növekedés leállását jelző sötét sáv). A mintából gyorsítós tömegspektrométerrel végzett radiokarbon elemzések készültek. A jelen cikk céljába nem tartozik bele a radiokarbon adatok részletes értelmezése, elegendő annyit megjegyezni, hogy a felszíni karbonát valóban modern karbont tartalmazott (a mészkőhozzájárulásra nem korrigált pMC érték $97,19 \pm 0.25$ ), a felszín alatt kb. 2 mm-rel vett minta modellezett kora pedig kb. 50-130 évvel ezelőtti képződésre utal (Molnár Mihály, ATOMKI, nem publikált adatai, 2020). A jelen tanulmány szempontjából érdekes jelenség a legfiatalabb $1 \mathrm{~mm}$-en belül látható, az oszlopos szövetű, tiszta kalcitot hirtelen turbulens, zárványgazdag kalcit váltja fel. 


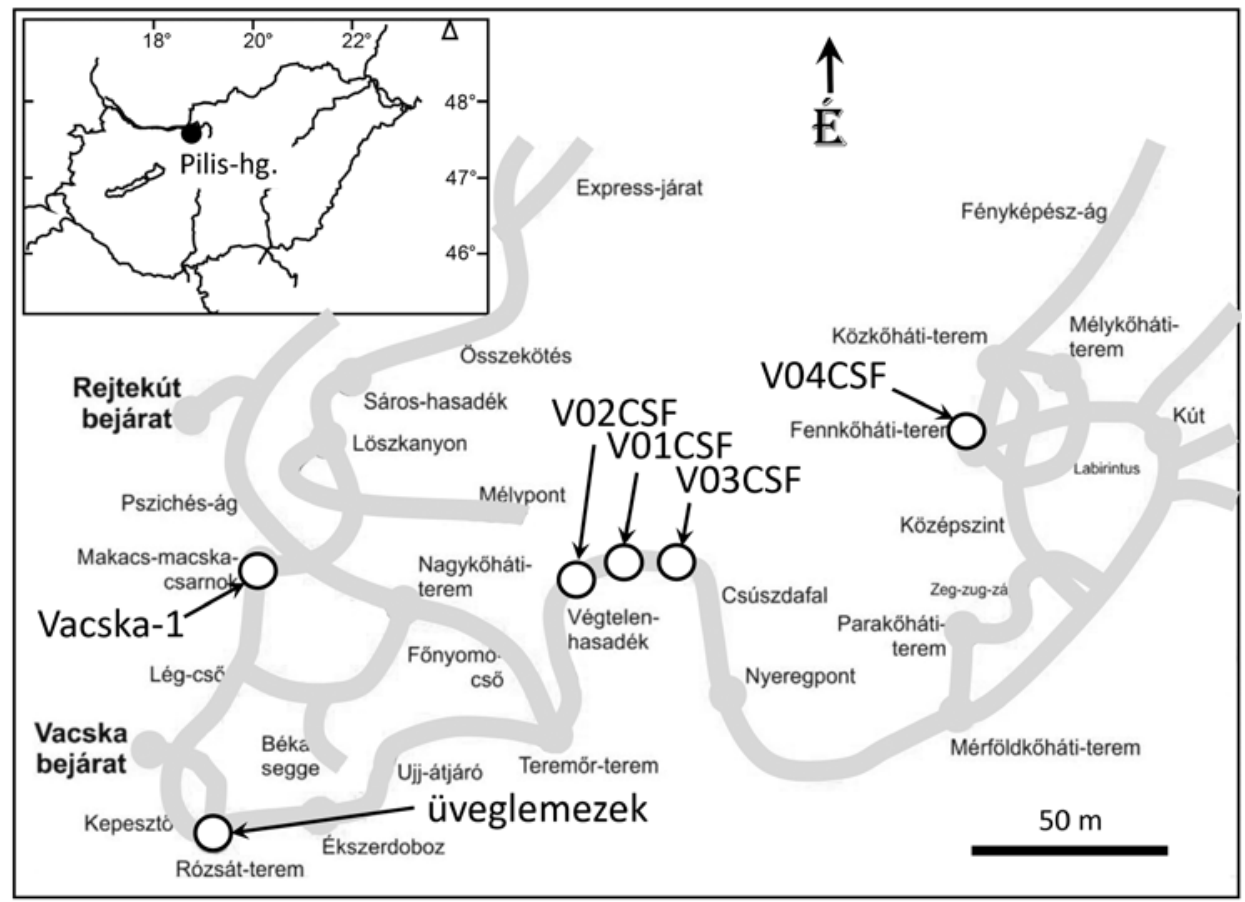

1. ábra A Vacska-barlang vázlatos felépítése a mintavételi helyszínekkel Figure 1 Schematic map of the Vacska Cave with sampling sites
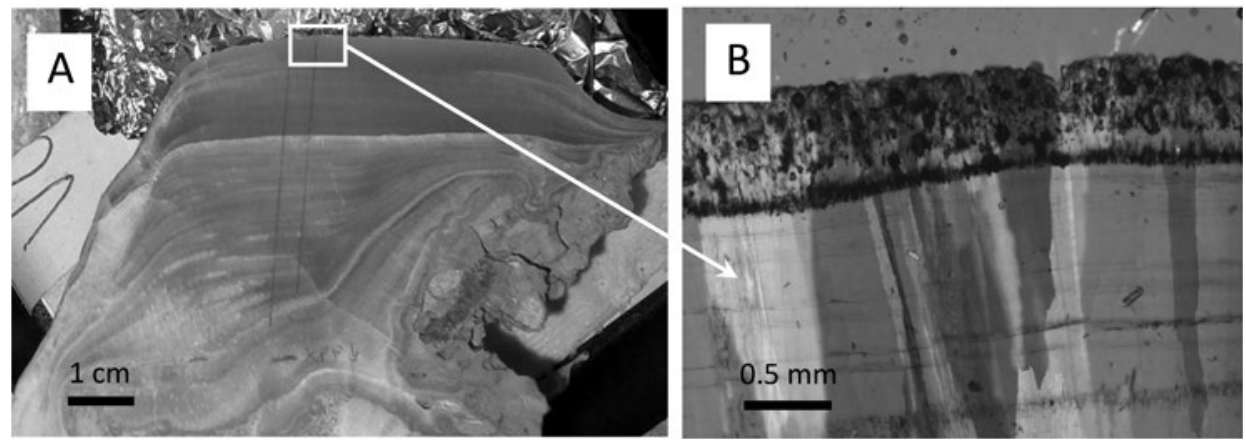

2. ábra A Vacska-1 cseppkő belső felépítése (A) és a legfelső réteg keresztezett nikollal készített optikai mikroszkópos képe (B)

Figure 2 Internal structure of the Vacska-1 stalagmite (A) and the optical microscopic picture of the youngest layer with crossed Nicols (B)

A cseppkő lelőhelyéhez legközelebbi olyan terem, ahol állandó csepegés volt megfigyelhető, a Rózsát-terem (1. ábra) volt, ahol hat ponton helyeztünk ki üveglemezeket a csepegés alá. Az üveglemezeket néhány havonta begyưjtöttük, megmintáztuk a csepegóvizet és mértük a fizikai és kémiai paramétereket. A hat pont közül egy esetében nem volt mérhető mértékú karbonátkiválás az üveglemezen.

A Vacska-barlang belseje felé haladva a Végtelen-hasadék lefolyásaiból (V01CSF, V02CSF, V03CSF, 1. ábra), valamint bejárattól legtávolabbi helyszínként a Fennkőháti- 
terem lefolyásából (V04CSF, 1. ábra) vettünk egy-egy fúrómag-mintát. A minták legfiatalabb 1-2 mm-én belül hiátusok (sötét sávként megjelenő, képződési szüneteket jelző felületek) jelentek meg, de a hiátusos képződés a fúrómagok egészében jellemző volt (3. ábra).

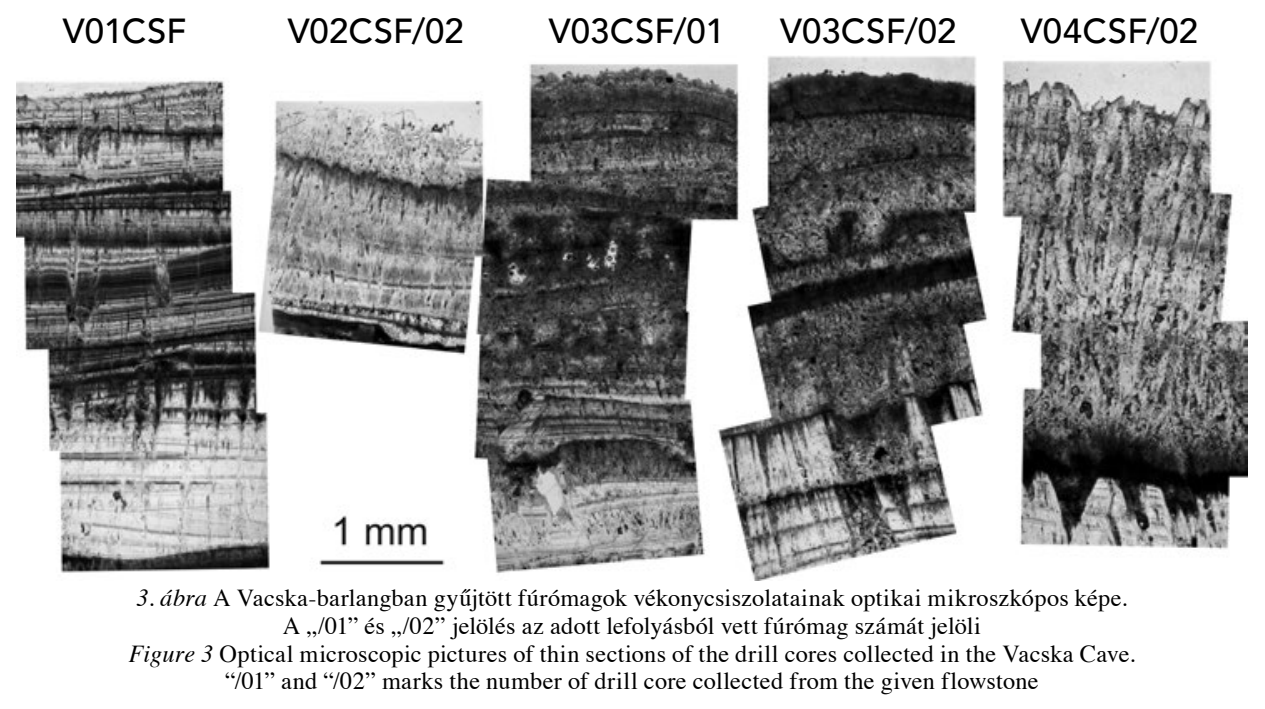

\section{Stabilizotóp-összetételek}

A cseppköveken elvégzett eddigi korvizsgálatok arra utalnak, hogy a Vacska-barlangban a cseppkőképződés üteme kb. 0.01-0.05 mm/év volt, így az első kb. $1 \mathrm{~mm}$ (kb. 20 elemzés) kb. 20-100 évet reprezentál. Erre való tekintettel mindegyik előfordulás külső 20 elemzését hasonlítottuk össze. Ez alól kivételt az üveglemezek képeztek, itt természetesen az összes üveglemez elemzése szerepel. Az elemzési adatokat a 4. ábrán ábrázoltuk.

A Vacska-1 cseppkő legkülső, turbulens, kb. $0.6 \mathrm{~mm}$ vastag rétegének (2.B ábra) összetételei jelentősen eltértek az alatta levő, tiszta kalcit összetételétől és 2,1-es meredekséggel pozitív $\delta^{13} \mathrm{C}-\delta^{18} \mathrm{O}$ korrelációt mutatnak, míg az alatta levő tiszta kalcit $\delta^{13} \mathrm{C}-\delta^{18} \mathrm{O}$ korrelációjának meredeksége 0.2. A Végtelen-hasadék V01CSF/01 fúrómagjának 20 elemzése általános pozitív $\delta^{13} \mathrm{C}-\delta^{18} \mathrm{O}$ korrelációt adott 1,9 -es meredekséggel, de a legkülső réteg nem tért el az alatta levőktől. Ennek alapján ez a lefolyás erős kinetikus frakcionáció alatt képződik, nem csak jelenleg, hanem a korábbi időszakokban is. A Végtelen-hasadék két másik mintázott lefolyásából vett három fúrómag mindegyikében a legkülső néhány elemzés eltolódott az alatta levőktől és 1,5-ös (V02CSF/02), illetve 2,1-es meredekségú (V03CSF/01 és 02), pozitív $\delta^{13} \mathrm{C}-\delta^{18} \mathrm{O}$ korrelációkat mutat. A bejárattól legtávolabbi vizsgált helyszínen, a Fennkőháti-teremben vett V04CSF/02 fúrómag adatai nem mutatnak korrelációt, a vizsgált kalcit pedig tiszta, oszlopos szerkezetû, ami együttesen egyensúlyi kiválásra utal.

A Rózsát-teremben gyújtött, üveglemezeken kivált karbonát nagyon erős pozitív $\delta^{13} \mathrm{C}-\delta^{18} \mathrm{O}$ korrelációt mutat (4. ábra), amelyen belül a bejárathoz legközelebb eső két pont adatai mutatják a legerôsebb eltolódást és kinetikus frakcionációt. Az üveglemezekre számított korreláció meredeksége 2,4, ami csaknem megegyezik a lefolyások és a Vacska-1 


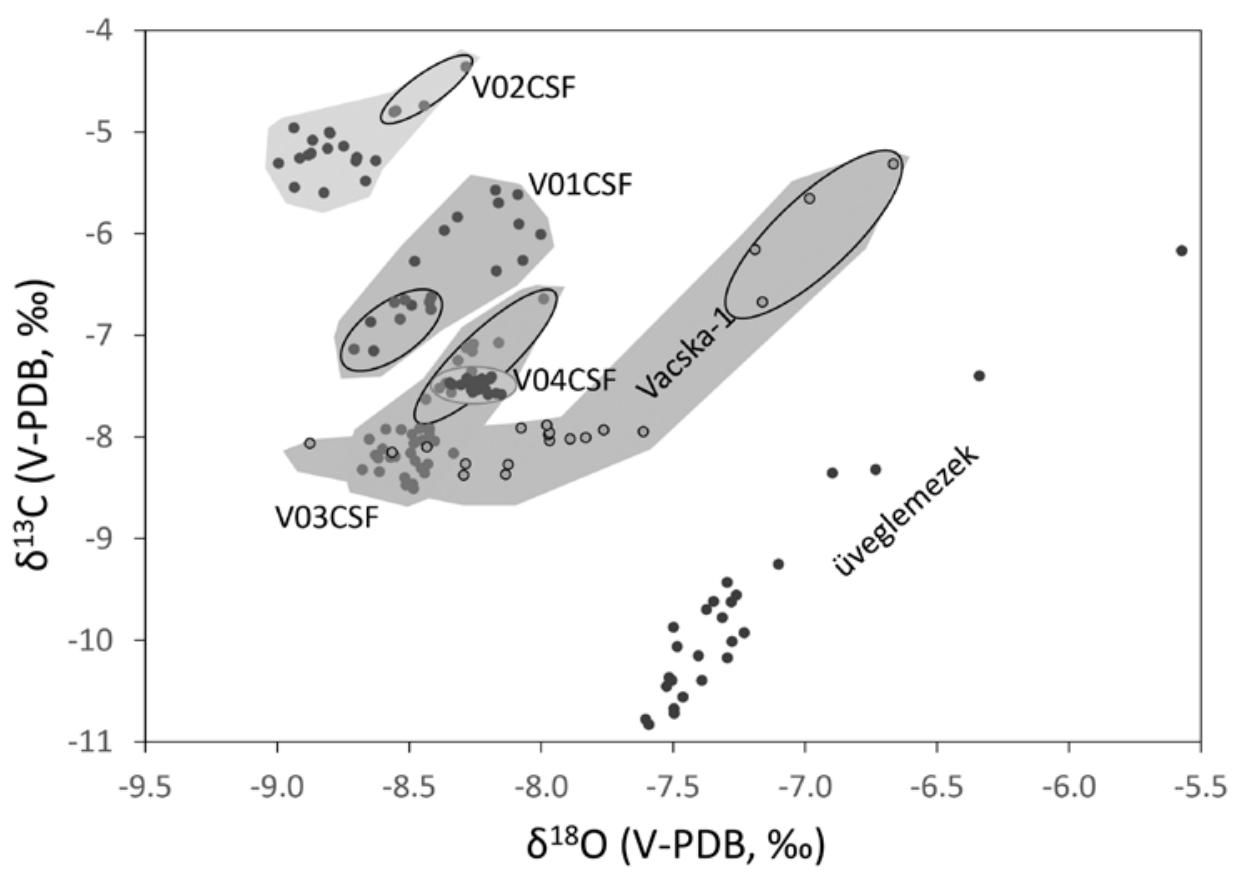

4. ábra A Vacska-barlangban gyưjtött Vacska-1 cseppkő, lefolyások és üveglemezeken kivált karbonát stabilszénés oxigénizotóp-összetételei. Az ellipszisek a legkülső elemzéseket mutatják

Figure 4 Stable carbon and oxygen isotope compositions of the Vacska-1 stalagmite, flowstones, and farmed calcites precipitated on glass plates within the Vacska Cave. Ellipses mark the isotope compositions of outermost layers

cseppkő külső rétegére kapott értékekkel. Ez arra utal, hogy a legkülső rétegekben megfigyelt $\delta^{13} \mathrm{C}-\delta^{18} \mathrm{O}$ eltolódás és frakcionáció az átszellőzöttség miatt bekövetkező kinetikus frakcionáció hatása.

\section{A megfigyelések következményei és javaslat a barlangi környezet megóvására}

A legkülső rétegben $\delta^{13} \mathrm{C}-\delta^{18} \mathrm{O}$ eltolódást és korrelációt mutató V02CSF és V03CSF fúrómagok esetében a kinetikusan frakcionált réteg vastagsága kb. 0,15-0,4 mm. A cseppkövek esetében megfigyelt képződési sebességek alapján a lefedett időszak 3-tól 40 évig terjed, ami azt jelzi, hogy az utóbbi néhány évtizedben történhetett olyan változás, ami a kinetikus frakcionáció felerősödéséhez és esetenként a karbonátképződmény szövetének változásához is vezetett. A fentiek alapján a Vacska-barlang bejáratához közeli, ső́t a még nem túl távoli helyszínek monitorozási adatai sem alkalmazhatóak a múltbeli összetételek értelmezéséhez. A kinetikus frakcionáció felerősödése a fokozott szellőzöttségnek tulajdonítható, ami feltételezhetően a barlangi járatok 2008-2010 során bekövetkezett összenyitásához kapcsolható.

Legtöbb barlangunk esetében egy mesterséges vagy természetes bejárat-kijárat van (budai-pilisi példákat tekintve ilyen jelenleg pl. a Ferenc-hegyi-, a József-hegyi, vagy a Sátorkőpusztai-barlang). Mégis, dacára a légáramlás évszakonkénti irányváltozásának, ezekben a barlangokban mindig jó és viszonylag alacsony széndioxid-tartalmú a levegó, tehát 
aktív légcseréjük van a fôte és a fölötte lévő kőzetréteg apró, az ember számára láthatatlan repedésein keresztül (LEÉL-ÔSSY-STIEBER 2015). Amíg nem készült mesterségesen az ember számára is járható méretû́ bejárat, csak gyenge légáramlás lehetett az eredetileg zárt rendszerként múködő barlangokban. Minél nagyobb a barlangi és a külső levegő hőmérséklete között a különbség, és minél nagyobb a barlang légtere, annál nagyobb, erősebb lesz a légáramlás (LEÉL-Ôssy 2017). A mesterséges megnyitás tehát mindenképpen beavatkozás a barlang életébe. A mesterséges bejáratokat ezért a barlang szempontjából is érdemes mindig zárva tartani.

További változásokat eredményezhet a légáramlásban több barlang „összekapcsolása”, a köztük lévő eltömődések kibontása esetén (1. az előző fejezeteket). Elég a négy nagyobb (egyenként is több km-es) és számos kisebb barlang „összenyitásával” létrejött Pál-völgyibarlangrendszerre utalnunk. Itt a 2001-es feltárás után a Pál-völgyi- és a Mátyás-hegyibarlang közti átjárót a barlangon belül is lezárták. De ez a helyzet pl. a Postojnai-barlang esetében is, ahol több ajtót is beépítettek a különböző, eredetileg különálló barlangok közötti mesterséges tárókba, amint azt a Magyar Karszt- és Barlangkutató Társulat 2018-as, a Postojnai-barlang csaknem valamennyi részét bejáró nyári tanulmányútján Leél-Ôssy Szabolcs személyesen tapasztalta.

Mint a jelen tanulmány eredményeiből is látható, a szellőzöttség nem csak a barlangi levegő tisztaságát és széndioxid-tartalmát érinti, de befolyásolja a cseppkőképződés mechanizmusát is. Amennyiben tehát a barlangi környezet és a cseppkőképződés természetes állapotát kívánjuk fenntartani, a járatrészek közé ismét lezárásokat vagy szúkítéseket kellene telepíteni, ami a szellőzöttséget csökkenti. Az emberi behatás nélküli környezeti állapot megóvása, illetve a feltárásokat és munkálatokat követően az eredeti környezet visszaállítása a barlangi környezetvédelem egyik fontos feladata. A jelen tanulmány a további paleoklimatológiai kutatás szempontjai mellett az illetékes Nemzeti Parkok figyelmét is felhívja a barlangrendszerek összenyitásának eddig fel nem ismert következményére, a cseppkőképződés mechanizmusának megváltozására.

\section{Köszönetnyilvánítás}

A tanulmány elkészítése az Eötvös Loránd Kutatási Hálózat által finanszírozott NANOMIN projekt (KEP-1/2020) keretén belül történt.

DEMÉNY ATTILA

ELKH CSFK Földtani és Geokémiai Intézet, Budapest demeny.attila@csfk.org

BERENTÉS ÁGNES

ELKH CSFK Földtani és Geokémiai Intézet, Budapest kaguar06@gmail.com

CZUPPON GYÖRGY

ELKH CSFK Földtani és Geokémiai Intézet, Budapest czuppon.gyorgy@csfk.org

KOVÁCS RICHÁRD

Duna-Ipoly Nemzeti Park Igazgatóság, Budapest ricsi1975@gmail.com 
LEÉL-ŐSSY SZABOLCS

ELTE TTK Általános és Alkalmazott Földtani Tanszék, Budapest

leel-ossy.szabolcs@ttk.elte.hu

\author{
SURÁNYI GERGELY \\ MTA-ELTE Geológiai, Geofizikai és Ǔrtudományi Kutatócsoport, Budapest \\ ELKH Atommagkutató Intézet, Debrecen \\ surda007@gmail.com
}

IRODALOM

Czuppon Gy.-Demény A.-LeÉl-Őssy Sz.-Stieber J.-Óvári M.-Dobosy P.-Berentés Á.-Kovács R. 2021: Monitoring and geochemical investigations of caves in Hungary: implications for climatological, hydrological and speleothem formation processes. Springer (in press)

DEMÉNY A. 2017a: Cseppkövek és klímakutatás: nanométerektől a kontinentális léptékig. - Magyar Tudomány, 178, pp. 1247-1261.

Demény A.-Kern Z.-CZuppon Gy.-Németh A.-LeÉl-Őssy Sz.-SiKlósy Z.-Lin K.-Hsun-Ming H.-Shen Ch-Ch.-Vennemann T.W.-HASzPRA L. 2017b: Stable isotope compositions of speleothems from the last interglacial - Spatial patterns of climate fluctuations in Europe. - Quaternary Science Reviews, 161,pp. 68-80.

Demény A.-Németh A.-Kern Z.-CZuppon Gy.-Molnár M.-LeÉl-Össy Sz.-ÓvÁRi M.-STIEBER J. 2017c: Recently forming stalagmites from the Baradla Cave and their suitability assessment for climate-proxy relationships. - Central European Geology, 60, pp. 1-34.

Demény A.-Kern Z.-Czuppon Gy.-Németh A.-Schöll-Barna G.-Siklósy Z.-LeÉl-Őssy Sz.-Cook G. -Serlegi G.-BAjnóczi B.-SüMegi P.-KirÁly Á.-Kiss V.-Kulcsár G.-Bondár M. 2019a: Middle Bronze Age humidity and temperature variations, and societal changes in East-Central Europe. - Quaternary International, 504, pp. 80-95.

Demény A.-Kern Z.-Németh A.-Frisia S.-Hatvani I.G.-Czuppon Gy.-LeÉl-Őssy Sz.-Molnár M. -ÓvÁri M.-SurÁNYi G.-Gilli A.-Wu CH.-CH.-ShEN CH.-CH. 2019b: North Atlantic influences on climate conditions in East-Central Europe in the late Holocene reflected by flowstone compositions. - Quaternary International 512, pp. 99-112.

Demény A.-Rinyu L.-Németh A.-CZuppon Gy.-Enyedi N.-MaKk J.-LeÉL-Ốssy Sz.-Kesjár D. - KovÁcs I. 2021: Bacterial and abiogenic carbonates formed in caves - no vital effect on clumped isotope compositions. - PloS ONE 16(1): e0245621.

Dorale J.A.-LiU Z. 2009: Limitations of Hendy test criteria in judging the paleoclimatic suitability of speleothems and the need for replication. - J. Caves Karst Stud., 71, pp. 73-80.

FAIRCHILD I.J.-BAKER A. 2012: Speleothem Science: From Process to Past Environments. Wiley-Blackwell.

Kern Z.-Demény A.-Persoiu A.-Hatvani I.G. 2019: Speleothem Records from the Eastern Part of Europe and Turkey - Discussion on Stable Oxygen and Carbon Isotopes. - Quaternary 2, Paper: 31.

LeÉL-Ôssy Sz. 2017: Caves of Buda Thermal Karst - In: Klimchouk, A., N. - PALmer, A.-De Waele, J.-Auler, A.S.-Audra, P. (eds.): Hypogene Karst Regions and Caves of the World). - Springer, Cham, Switzerland, pp. 279-298.

LEÉL-Össy Sz.-STIEBER J. 2015: Különös szén-dioxid szintek a Béke-barlangban. - Karsztfejlődés, XIX, pp. $225-230$.

Siklósy Z.-Demény A.-LeÉl-Őssy Sz.-Szenthe I.-Lauritzen S.E.-Shen Ch.-Ch. 2011: A cseppkövek kormeghatározása és azok paleoklimatológiai jelentősége. - Földtani Közlöny 141, pp. 73-87. 


\title{
A JELENLÉT NÉLKÜLI JELEN(LÉT) - A HAZAI PÁRTSZERVEZETEK FEJLETTSÉGÉNEK TERÜLETI KÜLÖNBSÉGEI
}

\author{
BÓDI MÁTYÁS \\ SPATIAL INEQUALITIES IN THE INSTITUALIZATION OF HUNGARIAN \\ POLITICAL PARTIES
}

\begin{abstract}
Numerous studies draw a direct link between party institutionalization and democratic (re) consolidation. The level of organization of a given political movement can easily determine their subsequent electoral performance. Not just in Hungary, but within the wider Central-EasternEuropean region, accessing data on party membership, branch offices, etc., is extremely challenging, therefore concluding or discovering party organizational strength is a critical research area. In this study I am making a bold attempt to unveil the social embeddedness of the most important political parties from the 2014 general elections to the latest EP elections (2019), by using the polling station table-seater delegates presence as an indicator of local party presence itself. I assume that, if a given party is not able to delegate a single person to a certain polling station, they have no operating organizations at the grassroots level, therefore it indicates their lack of localization and extensive network. With simple quantitative methodologies, I was also seeking the relationship between electoral performance and party organizational presence locally.
\end{abstract}

Keywords: electoral geography, party organizations, political geography

\section{Bevezetés}

A különböző hazai választásföldrajzi kutatások alaposan feltárták társadalmunk választói magatartásának térbeli jellegzetességeit. A társadalomtudományok által jól beazonosított politikai gondolkodásbeli törésvonalak (ENYEDI Zs. - KÖRÖSÉNYI A. 2001) térbeli mintázatai mentén, bizonyos mértékig tettenérhetőek és magyarázhatóak a pártpreferenciális, illetve egyéb voksolási jellegzetességek, amelyek akár választásról-választásra visszatérően kirajzolódnak (KovÁcs Z. 1991; HAJdú Z. 2006; JANKÓ F.-KOMORNOKI M. 2008; BóDI F.-Bódi M. 2011; Vida Gy.-KovÁcs Z. 2017; VidA Gy.-KovalcsiK T. 2018, stb.). Ezen kutatások fontos társadalmi összefüggéseket tárnak fel - ennek kapcsán említhetnénk a város-vidék dichotómia továbbélését a jobb-bal tengely mentén (VIDA GY.-KovÁcs Z. 2017) - amelyeken keresztül könnyebben érthetőbbé válnak a hazai politikai folyamatok is.

Ebben a tanulmányban arra tettem kísérletet, hogy a hazai pártok szervezeti fejlettségét, intézményesültségét, helyi társadalmi beágyazottságát mutassam ki, különös tekintettel a vizsgált jelenség területi jellegzetességeire. Arra keresem a választ, hogy az általam vizsgált négy, országos jelentőségú választási esemény (országgyuulési: 2014, 2018, Európai Parlamenti: 2014,2019) vonatkozásában, a felállított településkategóriák szerinti felosztásban, valamint a 106 országos egyéni választókerület (OEVK) szintjén mely pártok voltak képesek vizsgálatra érdemes számú pártdelegáltat eljuttatni a szavazóköri szavazatszámláló bizottságokba. Ahogyan azt a hasonló célú nemzetközi vizsgálatok is mutatják, pártok szervezeti állapotára vonatkozó adatokat (pl. párttagok száma és lokációja, alapszervezetek elhelyezkedése) szinte képtelenség megszerezni, ezért meglátásom szerint az egyetlen olyan hiteles adatot használtam fel, amely a Nemzeti Választási Iroda (NVI) szavazóköri jegyzőkönyveiben rögzített. 
Egy rövidebb nemzetközi szakirodalmi áttekintést követően, melyben szerettem volna a helyi pártjelenlét és az eredményes választási szereplés közötti összefüggés elméleti alapjait lefektetni, megvizsgálom, hogy a szavazóköri pártdelegáltak jelenléte, milyen területileg kitapintható jellegzetességekkel bír. A tanulmány záró részében pedig az egyes pártok szavazóköri jelenlétét megpróbálom összefüggésbe hozni az adott szavazókörben elért választási eredményével, ezáltal empirikusan megvizsgálni, hogy valóban kimutatható-e összefüggés a két változó között. Végezetül ezeket az összefüggéseket egy kormány - ellenzék szembeállításban is elemzem. A választási eredményeket az adott pártra leadott listás szavazatok százalékában mértem.

\section{Választási földrajzi kutatások és a területiség szerepe a hatalom megszerzésében}

A választási eredmények térbeli elemzésének van egy tisztán hatalomtechnikai aktualitása is. A választási törvény 2011-ben megkezdett módosításainak eredményeként a vegyes választási rendszer ugyan megmaradt, de annak többségi elemei rendkívül felerősödtek (SzIGETi P. 2013; Tóтн Cs. 2017), mivel a parlamenti mandátumok több mint felének sorsáról,immáron az egyéni választókerületekben döntenek a választópolgárok. Nem beszélve arról a legfeljebb nyelvi oximoronként értelmezhető, ún. ,győztes-kompenzációs” töredékszavazat-számítási mechanizmusról, amely szintén a választókerületi jelöltekre leadott voksokra vezethető vissza.

Legszemléletesebb metaforát a többségi karakter jelentőségéről Tölgyessy Péter, a rendszerváltás során konszenzuálisan elfogadott korábbi választási rendszer egyik szellemi atyja tudta megalkotni, amikor ahhoz a játszótéri libikókához hasonlította azt, amely amint átbillen az egyensúlyi ponton, hatalmas erővel csapódik a földbe (TöLGYESSY P. 1015).

Ennek megfelelően felerősödött egy olyan gondolkodásmód a helyi hatalom gyakorlói részéről is, amelyben az országgyưlési választókerület vált azzá a területi egységgé, amin belül területfejlesztési terveiket elképzelik (PÁLNÉ KovÁCs I. 2019), alapvetó politikai stratégiáikat felépítik. Ez már csak azért is egy teljesen abszurd hatalmi megközelítés, mivel az országgyúlési választókerületek határai, számos esetben még a területi politikai rendszer alapegységeinek tekinthető önkormányzatok (KÁKAI L.- VETő B. 2019) közigazgatási határaira sincsenek tekintettel (pl. Miskolc, Pécs, Szeged, Nyíregyháza esetében), jóllehet ez az előző választási rendszernek is egyfajta sajátossága volt.

Napjainkra, az ismételten gyakorlatilag kétpólusúvá váló hazai politikai színtéren, az egyéni választókerületi küzdelmek tehát felértékelődnek, arról nem is beszélve, hogy az ún. győztes-kompenzáció bevezetését követően, a nyertesek a választókerületekből is tudják gazdagítani a listás szavazattömeget. 2018-ban ennek pl. döntó jelentősége volt a kormánypárt ismételt kétharmados győzelmében (LÁszLó R. 2018). Mindezek ismeretében nem meglepő, hogy a hazai nyilvánosságban mára olyan észak-amerikai terminusokkal is találkozhatunk, mint a magyar „swing-state”, vagy „szupercsatatér” (STUMPF A. 2021) körzetek kifejezése. A választókerületek, az ott élő választópolgárok minél átfogóbb ismerete tehát kulcsfontosságú a jelenlegi választási szisztémában.

A fentiek okán, valamint a soron következő 2022-es országgyúlési választásokra való tekintettel is, indokolt az általam felvezetett vizsgálat lefolytatása, hiszen pont azt mutatom be a használt indikátor segítségével, hogy mely pártok, illetve a kormány - ellenzék viszonyában, melyik szereplő rendelkezik az adott OEVK-ban jobban kiépült pártszervezettel. Mindazonáltal, retrospektív jelleggel azt is tanulmányozom, hogy az adott OEVK-n belül mért magas szavazóköri delegálási potenciál magával hozta-e a párt jobb választási szereplését, mivel a felhasznált nemzetközi tanulmányok ennek a hipotézisnek a megerôsítésére engednek következtetni. 


\section{Pártszervezetek és azok lokális jelentősége}

A választási eredmények területi szempontú vizsgálata tehát széles körben ismert kutatási irány. Ebben a tanulmányban azonban arra szeretnék kísérletet tenni, hogy a hazai politikai pártok intézményesültségét, társadalmi beágyazottságát, szervezeti fejlettségét vizsgáljam meg hasonló megközelítésben. Ezt azért is tartom egy fontos gondolatkísérletnek, mert a már említett kétosztatú politikai színtér ellenzéki oldala egy rendkívül heterogén politikai közösségből épül fel. Török Gábor politológus úgy fogalmazta ezt meg a 2019es önkormányzati választások másnapján, hogy az „,...ellenzéki politika ma egy felhó”, amiben rendkívül sokfajta szereplő van, nem csak kizárólag pártok (TöRöK G. 2019). Ezen csoport szereplői, mint ahogyan azt a későbbiekben igyekszem érzékeltetni, nagyon különböző érettségú és stratégiájú szervezetek halmaza, amelyek intézményi fejlettsége, lokális fizikai jelenléte területileg is nagyon differenciált képet mutat.

A hazai és a nemzetközi szakirodalomban egyaránt szakmai konszenzus övezi azt a megállapítást, mely szerint, pártok választási sikerének egyik alapfeltétele a jól kiépült szervezet vagy országos lefedettséggel rendelkező tagság, aktivista hálózat (például: TAVITS M. 2012, 2014; Gerghina S. 2014; Riberio P.F. - LoCATElli F. 2019; HALVORSEN S. 2019, SCOTt J.WILLS J. 2017). Természetesen létezik egy sor egyéb olyan szempont is, amelyek az adott politikai kontextustól függetlenül döntőek lehetnek, mint például az adott párt strukturális felépítése (központosított és vezérelvú, vagy inkább bázisdemokrata). Többen azt is kiemelik, hogy egy harmonizált térszerkezettel rendelkező pártstruktúra jelentősen hozzájárulhat ahhoz, hogy az adott politikai közösségen belül, kellő mértékben legyenek reprezentálva és artikulálva az ország különböző vidékeinek társadalmi problémái, ami szintén egy sikeres párt alapfeltétele (ScotT J.-Wills J. 2017, az olasz Öt Csillag Mozgalom példáján: Mikola-Oross 2018).

A politikatudomány számára különösen érdekes vizsgálati terepet jelentenek a fiatal demokráciák, az ott létrejövő pártosodás társadalmi jelenségei. (Szubszaharai-Afrika államai kapcsán: BASEDAU M.-STROH A. 2008, Dél-Amerika országai kapcsán: RIBERIO P.F.-LOCATELLi F. 2019, a posztszocialista európai országok kapcsán: TAVITS M. 2012; GERGHINA S. 2014; Pete M. 2016). Mindazonáltal rendkívül tanulságos munkák születtek a legnagyobb múltra visszatekintő parlamentarizmusban, Nagy-Britanniaban is, különös tekintettel a Munkáspárt helyi közösségépítési gyakorlatára támaszkodó szervezetfejlesztésére (SCOTT J.-WILLS J. 2017). Ezeket megelőzően átfogó elemzések láttak napvilágot az Egyesült Államok kapcsán egyaránt (FRENDREIS J. P. et al. 1991). Ezen munkák túlnyomó többsége azonban nem kísérelik meg az országos szintnél granulárisabb nézópontok érvényesítését, habár üdítő kivételek léteznek, azonban azok szerzői is többnyire politikai földrajzzal foglalkozó geográfusok (Argentína kapcsán: HALVORSEN S. 2019). Nem tudhatjuk meg belőlük, hogy az adott politikai mozgalmak mennyire tudtak gyökeret ereszteni a vizsgált országok különböző térségeiben. Márpedig, ha elfogadjuk, azt az alapvetést, mely szerint a sikeres párt receptje a kiterjedt tagság és kiépült pártszervezet, pártirodák hálózata, akkor szükségképpen nem elégedhetünk meg egy általános országos képpel hazánk esetében sem. Miközben azonban finoman kárhoztatjuk a politikatudományt a területi dimenzió negligálásáért, nem mehetünk el szó nélkül amellett, hogy a megszerezhető adatok tekintetében egy rendkívül érzékeny kutatási területról beszélünk. Politikai mozgalmak, pártok, nem szívesen adnak ki információkat a tagságukkal, alapszervezeteikkel, pártirodáik lokációjával kapcsolatosan, ami különösen igaz azokra az országokra, amelyek valamilyen önkényuralmi rendszer igája alól, relatíve frissen szabadultak fel (TAVITS M. 2012). Az általam hivatkozott észt származású amerikai politológus, Margit TAVITS például ennek áthidalására az önkormányzati választások egyéni jelöltjeinek párt 
színezetét vette alapul számitásaiba hazánk és Lengyelország esetében (TAVITS M. 2012. és 2014.), feltételezvén, hogy ha egy párt legalább egy jelöltet képes kiállítani helyi szinten, azzal kimutatható a párt jelenléte is.

Az általam vizsgált időszak hazai főszereplőinek pártszervezeti fejlődése, szintén alaposan feltárt kutatási terület (MSZP kapcsán: LAKNER Z. 2017; Fidesz: ENYEDI Zs. 2004; BÉKÉS M. 2008; BALÁZS Z.-HAJdÚ A. 2017, valamint rendszerszinten átfogó jelleggel: KÖRÖSÉNYI A. et al. 2020; Jobbik: RóNA D. 2016). Területileg differenciált adatokkal vagy megállapításokkal ezekben sem találkozunk ugyan, de a pártszervezetek belső állapotáról, vagy azok korábbi kialakítása, fejlesztése kapcsán nagyon alapos kutatásokat végeztek a szerzők. Külön említést érdemel Tóka Gábor korai munkája (TóKA G. 1991), melyben a harmadik magyar köztársaság, elsô szabadon megtartott önkormányzati választása során, a pártok jelöltállítási potenciálját vizsgálva próbál következtetni a pártszervezetek fejlettségére. Ez ugye a Tavits féle 2012-es nemzetközi kutatás módszertanára emlékeztető, azonban azt messze megelőző vizsgálati megközelítés volt.

Egy másik, alapvetően Magyarországra sajnálatosan nagyon jellemző kutatási problematika, a magyar társadalom, tömeges (politikai) állampolgári részvételének nagyfokú hiánya, amely már a harmadik magyar köztársaság kezdeti legitimizációs válságát is okozta (TÖLGYESSY P. 2019). Ennek, vizsgálatunkból fontos szempontja, a pártok, nemzetközi összehasonlításban is alacsony taglétszáma (RIBERIO P.F.-LOCATELLI F. 2019). Egykoron gyakorló politikus-pártelnök megfogalmazásában ugyanez, így hangzik: „Az állampolgári részvétlenség az ezredfordulóra (...) válságba sodorta a magyar politikai rendszert. A pártok kiürültek, elveszítették képességüket, hogy tényleges társadalmi érdekeket aggregáljanak, magyarul rendeltetésszerüen müködjenek.” (SCHIFFER A. 2017).

\section{A pártok társadalmi beágyazottságának egy lehetséges merőszáma - A vizsgálat módszertana}

A választási eljárásról szóló törvény (2013. évi XXXVI. törvény a választási eljárásról 28. § (4), illetve 29. §) értelmében a választások alkalmával a szavazatszámláló bizottságokba (szavazókörökbe) az adott választókerületben jelöltet állító, vagy országos listával rendelkező pártok is delegálhatnak 2-2 szavazatszámláló biztost (pártdelegáltak), valamint a függetlenként induló egyéni jelöltek számára is nyitva van ez a lehetőség. A pártok számára fontos a szavazóköri jelenlét, a szavazatszámlálás folyamatának felügyelete. Erre még a választások során annak tisztaságát felügyelő nemzetközi szervezetek (EBESZ, Velencei Bizottság) is kitérnek a választási események ról szóló beszámolójukban (EBESZ/ODIHR. 2014 és 2018). Hazánkban nagyjából 10 ezer szavazókörben bonyolítják le a választásokat. Ez a szám az országgyúlési választások alkalmával pár 100 szavazókörrel több, az EP voksolások alkalmával kevesebb. Nyilvánvalóan annak megszervezése, hogy a választás napján a közel 10 ezer szavazókör mindegyikébe legalább egy, de ideálisabb esetben (gondolva a mozgó urnáztatásra is) két delegáltat el tudjon juttatni egy párt, elképesztően nehéz feladat, melyet csak egy komoly szervezeti háttérrel rendelkező politikai erő képes megoldani.

Az egyes pártok szervezeti fejlettségének tettenérésére a fentiek okán a választások alkalmával a szavazókörökbe megjelent pártdelegáltak adatait vettem alapul. A kormány - ellenzék összehasonlítás során figyelmen kívül hagytam a különböző anyagi haszonszerzés és egyéb „zavarórepülés” céljából létrehozott alkalmi szervezeteket, azonban azon független jelöltek (pl. dr. Mellár Tamás, Kész Zoltán) delegáltjait az ellenzékhez soroltam, akik nyíltan az ellenzéki pártok támogatását élvezték. A 2014-es parlamenti voksolás alkalmával, az Összefogás pártjai (MSZP, DK, Együtt, Párbeszéd, Magyar Liberális Párt) 
közös listán és közös egyéni jelöltekkel vágtak neki a küzdelemnek, így a választási törvénynyel összhangban, a pártdelegáltak is eképpen szerepelnek az NVI szavazóköri jegyzőkönyveiben. Természetesen a pártdelegáltak nem szükségszerúen párttagok, azonban vizsgálatom szempontjából éltem azzal a feltételezéssel, hogy egy párt ilyetén megnyilvánuló képviselete erős szervezeti kapcsolatot feltételez. Számos beszélgetést folytattam aktív politikai szereplőkkel, akik a vizsgálatom tárgyát kepéző pártok operatív feladatait látják el. Egybehangzóan megerősítették, hogy a pártdelegáltak számára a választásokat megelőzően tájékoztató anyagokkal, képzésekkel készülnek, amelyek több alkalmat is felölelnek. Ebből arra következtettem, hogy ezek az emberek az adott pártokhoz szorosan kötődo, azok felé elkötelezett, és ami a legfontosabb, szervezetileg is kapcsolódó helyi szereplők. Természetesen egy adott településen a választás napján ilyenformán szolgálatot teljesítő delegált nem szükségszerúen az adott település lakója. Mindazonáltal azt szintén megerôsítették a pártok, hogy jellemzően ezek a pártdelegáltak nem mozgathatók saját településüktől messzire.

A vizsgálatba, a legutóbbi két országgyúlési $(2014,2018)$ valamint szintén két európai parlamenti $(2014,2019)$ voksolás adatait használtam fel, amelyet az NVI bocsátott rendelkezésemre, szavazóköri szinten. Az önkormányzati választások adatait, a pártfüggetlen jelöltek rendkívül magas és településmérettől függő száma miatt nem használtam fel ebben a vizsgálatban. Az adatokat települések, valamint országos egyéni választókerületek (OEVK) szintjére aggregáltam (EP voksolások esetén, a címnyilvántartás alapján önkényesen), majd előbb horizontálisan, tehát települések jogállása és lakónépessége alapján kialakított kategóriák szerint vizsgálódtam. Ezt követően, OEVK szinten folytattam az elemzést. Már az adatok feldolgozásának kezdeti szakaszában felmerült, hogy érdemes lenne egy kormány - ellenzék összehasonlítást retrospektív jelleggel is felállítani a vizsgált választási események kapcsán. Habár 2014-re egyértelmúen hárompólusúvá vált a hazai politikai színtér (VIDA GY.-KovÁCs Z. 2017), a jelenlegi politikai kétosztatúságra, amely a 2019-es önkormányzati választások idejére intézményesült formában is testet öltött, valamint a 2022-es országgyuulési választásokra tekintettel tartottam szükségesnek ezt a fajta distinkciót. Mindezeken felül, beazonosítottam azokat a szavazóköröket is, amelyekbe kizárólag a kormánypárt tudott delegáltat eljuttatni. Ezt azért tartottam szükségesnek, mert a Fidesz-KDNP delegálási potenciálja magasan kiemelkedik a mezőnyből, mind a négy vizsgált esemény, de különösen az EP választások során (2014-ben a szavazókörök 21\%-ban, 2019-ben már a 25\%-ban kizárólag a kormánynak volt pártdelegáltja). Ami viszont még ennél is tanulságosabb, hogy ezt a logisztikai feladatot úgy tudta megoldani, hogy mindeközben földrajzilag rendkívül egyenletesen fedte le az ország szinte teljes egészét. Ezzel szemben az ellenzék pártjai, számos esetben alig voltak képesek megjelenni az ország egyes, egymással földrajzilag összefüggő vidékein.

A településtípus szerinti horizontális, majd EOVK szintű elemzést követően, a kapott szavazóköri pártdelegált eredményeket összevetettem a választások, pártlistákra leadott szavazati eredményeivel. Ezzel szeretném megvizsgálni azt a hipotézist, mely szerint az erős pártszervezeti jelenlét (tehát esetünkben, a pártdelegáltak száma), összefüggésben áll a párt választási eredményességével, ahogyan azt több nemzetközi tanulmány is állítja (TAViTs M. 2012; SCOTT J.-WiLls J. 2017). Az egyéni jelöltekre leadott szavazatok nem képezik ennek a vizsgálatnak a tárgyat, hiszen az EP választások alkalmával csak listákra szavazunk. Továbbá 2018-ban a taktikai szavazás jelensége, mint országos szinten precedens nélküli választópolgári stratégia (VIDA Gy.-KovALCSIK T. 2018) erősen torzítja az eredményeket, nem beszélve a DK - MSZP, OEVK szinten köttetett választási koordinációs együttmúködésről 2018-ban.

A területi szint megválasztása kapcsán, fontos kiemelni, hogy a 2014-ben debütáló új választási rendszerben, az alkalmazott új földrajzi lehatárolás aránytalanságai („,malapportionment”, ,garrymendering”), „földrajzi torzulásai” (VIDA Gy. 2020), némileg deter- 
minálták vizsgálatom egyes eredményeit. Ez elsősorban annak volt köszönhető, hogy a kormánypártok támogatottsága immáron egyenletesebben oszlott el a választókerületek között. Ezzel szemben, a baloldali pártok szavazóinak térbeli eloszlása, 2014-rôl és 2018-ra, egy erős térbeli koncentráción ment keresztül az urbánusabb kerületek javára (VIDA Gy. 2020), amit, mint azt a következőkben be is mutatom, követett a baloldali pártdelegáltak folyamatos kiszorulása a vidéki szavazókörökből is. A ,garrymendering” torzító hatása, még a térben harmonikusabb támogatottsággal bíró Jobbikkal kiegészült ellenzékkel szemben is, a jelenlegi kormányzópártoknak kedvezne egy kétosztatú politikai küzdelem során.

\section{Pártjelenlét a választások napján a településméret függvényében}

A vizsgált négy választás alkalmával a Fidesz-KDNP kimagasló hatékonysággal tudta „benépesíteni” a magyarországi szavazóköröket. Ha úgy tetszik, ennek a képzeletbeli pártok közötti versenynek (is) a kormánypártok az abszolút győztesei. A leggyengébb országos adatot a 2018-as országgyưlési választás alkalmával produkálta a párt, ekkor „csupán” a szavazókörök 95\%-ában volt jelen. Kissé meglepő, hogy olyan szavazókörök jegyzőkönyveiben sem találni kormánypárti delegáltat ekkor, mint például egy kivételével az összes mohácsi (ellenben a DK delegáltja jelen volt mindegyikben), vagy Nyíregyháza több tucat szavazóköre, ahol viszont az NVI adatai alapján az ellenzéknek sem volt képviselője. A többi vizsgált választás alkalmával ez a szám rendre 98-99\% körül mozgott. Településtípusonkénti bontásban vizsgálva szinte alig látunk eltérést (1.táblázat), azonban az szembetúnő, hogy a településhierarchia legalacsonyabb fokain, már az amúgy elképesztô hatékonysággal múködő pártszervezetnek is voltak relatív logisztikai nehézségei (500 fó alatti kategóriában 2018-ban: 76\%). Ezt leszámítva, a kormánypártok teljesítményét még csak megközelíteni sem tudta egyetlen ellenzéki szervezet sem. Ellenzéki térfélen a leghatékonyabban delegáló párt vagy pártszövetség kiléte választásról választásra változott.

1. táblázat - Table 1

Pártdelegáltak a szavazókörök \%-ában a legutóbbi két országgyűlési választás alkalmával, településtípusonként.

Party delegates in \% of polling stations in the last two parliamentary elections, by type of municipality.

\begin{tabular}{|c|c|c|c|c|c|c|c|c|c|}
\hline & \multicolumn{4}{|c|}{2014 Országgyúlési } & \multicolumn{5}{|c|}{2018 Országgyúlési } \\
\hline & Fidesz & Jobbik & $\begin{array}{l}\text { Össze- } \\
\text { fogás }\end{array}$ & $\begin{array}{c}\text { csak } \\
\text { Fidesz } \\
\end{array}$ & Fidesz & Jobbik & MSZP & DK & $\begin{array}{c}\text { csak } \\
\text { Fidesz }\end{array}$ \\
\hline Buda & 100,0 & 79,8 & 95,0 & 2,9 & 99,8 & 76,2 & 65,0 & 40,1 & 2,1 \\
\hline $20000-*$ & 99,7 & 77,3 & 98,6 & 0,7 & 96,5 & 74,5 & 62,0 & 23,9 & 5,4 \\
\hline 10000-20000 & 97,9 & 86,8 & 96,2 & 0,4 & 97,4 & 86,4 & 65,7 & 23,5 & 2,8 \\
\hline $5000-10000$ & 97,8 & 80,1 & 90,8 & 3,2 & 99,6 & 82,6 & 52,1 & 21,6 & 7,1 \\
\hline $1000-5000$ & 98,9 & 66,9 & 82,0 & 6,7 & 96,5 & 72,8 & 39,3 & 14,1 & 12,5 \\
\hline $500-1000$ & 96,5 & 42,9 & 64,8 & 20,1 & 91,1 & 51,6 & 27,5 & 7,3 & 27,8 \\
\hline-500 & 93,8 & 16,9 & 42,4 & 44,8 & 76,3 & 28,5 & 11,7 & 2,6 & 42,6 \\
\hline Magyarország & 98,3 & 67,4 & 84,7 & $\mathbf{8 , 8}$ & 94,6 & 69,5 & 48,5 & 20,0 & 12,3 \\
\hline
\end{tabular}

* Budapest nélkül

Forrás: NVI, saját szerkesztés

Source: NVI, own compilation 
A 2014-es Összefogás a szavazókörök 85\%-ban jelen volt ugyan az országgyúlési választásokon, azonban 2018-ra a leghatékonyabb ellenzéki szervezet szerepét egyértelmúen átvette a Jobbik (70\%). A baloldali pártok esetében különösen meghatározó volt a településméret. Saját országos átlagukhoz képest sokkal alacsonyabb hatékonysággal tudták képviseltetni magukat az 5 ezer főnél kisebb népességű településeken. A baloldali tömbön belüli differenciáltság már a 2014-es EP választás vizsgálatával tapintható ki igazán, ugyanis itt már külön listán indultak ezek a pártok. Szembeötlő, hogy az 5 ezer főnél kisebb lakosságú településeken a szocialisták rendelkeztek nagyobb arányban szavazóköri delegáltakkal, míg ugyan itt a DK és az Együtt-PM emberei szinte alig voltak jelen. A 2018-as választásokra ez a kép döntóen nem módosult, mivel az MSZP kétszer annyi szavazókörben volt jelen, mint a DK, amelynek még továbbra is jelentôs akadályt jelentett a községi jogállású településeken történő reprezentáció (8\%), míg ezzel szemben a fővárosi szavazókörök már több mint 40\%-ban fel tudott vonultatni delegáltat.

A 2019-es EP választás eredménye alapvetôn átrendezte az ellenzéki térfél politikai erőviszonyait, a DK érezhetően előrébb tudott lépni az alacsonyabb népességú települések szavazóköreiben a delegálást illetően is (2. táblázat). Érdemes azt is kiemelni, hogy a Demokratikus Koalíció volt az egyetlen ellenzéki parlamenti párt, amely abszolút számban több delegáltat tudott eljuttatni a legutóbbi EP választás alkalmával az urnák mellé, mint az azt megelőző 2018-as országgyúlési választáson. Ehhez persze kellett a Jobbik példátlan mértékú szervezeti visszaesése is 2019-re. Mindazonáltal nagyon fontos kiemelni, hogy a Magyar Szocialista Párt, a szavazóköri delegálásokat illetően az egyetlen olyan szereplője a magyar politikai színtérnek, amely a Fidesz mellett (habár kisebb mértékben és településmérettől függóen differenciáltan) valamilyen fajta állandóságot és szervezeti stabilitást tudott felmutatni választásról választásra (közel 50\%-os delegálás országos mind a négy választáson).

2. táblázat - Table 2

Pártdelegáltak a szavazókörök \%-ában a legutóbbi két Európai Parlamenti választás alkalmával, településtípusonként.

Party delegates in $\%$ of polling stations in the last two European Parliament elections, by type of municipality.

\begin{tabular}{|c|c|c|c|c|c|c|c|c|c|c|c|c|c|}
\hline & \multicolumn{6}{|c|}{2014 EP } & \multicolumn{7}{|c|}{2019 EP } \\
\hline & 胥 & $\frac{1}{0}$ & $\frac{\hat{N}}{\sum^{2}}$ & 光 & 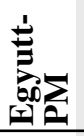 & 苞通 & 赵 & 商 & $\sum_{\Sigma}^{0}$ & 光 & $\stackrel{\dot{\Xi}}{\stackrel{\Xi}{\Xi}}$ & 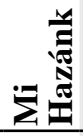 & 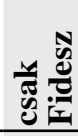 \\
\hline Budapest & 99,9 & 77,7 & 72,8 & 24,4 & 18,4 & 2,3 & 99,1 & 28,3 & 67,2 & 53,1 & 10,8 & 7,6 & 2,8 \\
\hline $20000-*$ & 99,4 & 66,7 & 66,0 & 13,3 & 10,6 & 6,1 & 100,0 & 33,0 & 65,5 & 31,9 & 4,2 & 7,0 & 7,8 \\
\hline $10000-20000$ & 98,6 & 70,3 & 66,4 & 17,3 & 4,7 & 5,3 & 99,0 & 37,7 & 57,5 & 30,9 & 1,5 & 6,3 & 12,6 \\
\hline 5000-10000 & 99,7 & 66,8 & 54,5 & 11,0 & 3,6 & 13,2 & 100,0 & 33,0 & 42,6 & 27,9 & 1,5 & 2,7 & 25,7 \\
\hline $1000-5000$ & 98,4 & 46,7 & 39,4 & 8,4 & 3,5 & 29,4 & 98,2 & 26,8 & 34,0 & 18,5 & 0,7 & 4,0 & 35,1 \\
\hline $500-1000$ & 97,4 & 28,5 & 27,3 & 6,9 & 2,5 & 47,5 & 99,6 & 15,6 & 19,6 & 12,5 & 0,7 & 2,7 & 58,7 \\
\hline-500 & 98,1 & 11,0 & 13,5 & 2,6 & 0,3 & 74,9 & 96,8 & 10,4 & 9,1 & 5,4 & 0,1 & 1,5 & 76,5 \\
\hline Magyarország & 98,9 & 55,6 & 51,7 & 12,5 & 7,2 & 21,5 & 99,0 & 28,1 & 47,0 & 27,4 & 3,1 & 5,1 & 25,6 \\
\hline
\end{tabular}

* Budapest nélkül

Forrás: NVI, saját szerkesztés

Source: NVI, own compilation 
A Jobbik a legutóbbi EP voksolást leszámítva, rendkívül fontos szerepet tölthetett be az ellenzék szempontjából a szavazókörökben. A jobbikos alapszervezetek azért is lehettek fontosak, mert a baloldali pártokkal ellentétben a településhierarchián lefelé lépkedve, nem jellemezte őket az azzal arányos alulreprezentáltság. A Jobbik jelölési potenciálja jellemzően a közepes méretû településeken volt a legerősebb (pl. 5-20 ezer fós települések esetében magasan 80\% feletti szavazóköri jelenlét 2018-ban, de az 500 fónél alacsonyabb lélekszámú aprófalvas szavazókörök több mint negyedében is jelen volt a párt). Ugyanakkor a 2019-es EP választásokra már rendkívül kedvezőtlen szervezeti feltételek mellett voltak kénytelen nekifutni (Vona Gábor visszavonulása, milliárdos ÁSZ büntetés, a Mi Hazánk alapítótagjainak kiválása stb.), ami a delegálási potenciáljukra is erôsen rányomta a bélyegét. A Jobbik 2019-ben mindössze a szavazókörök alig több mint negyedében tudott megjelenni, azonban ezt nem magyarázza a Mi Hazánk létrejötte, amely a szavazókörök mindössze 5\%-ban bukkant fel.

Említést érdemel még egy jelenség, ami viszont teljesen kontextus nélküli vizsgálatunk szempontjából és talán kissé rámutat annak egyik módszertani fonákságára is. A 2014-es országgyúlési választások szavazóköri jegyzőkönyveinek összesített adatai alapján a Fidesz, az Összefogás és a Jobbik hármast követôen, a negyedik legtöbb szavazatszámláló delegáltat (1179 fó, 802 szavazókörben) a Magyarországi Cigánypárt (MCP) tudta mozgósítani, ami azért is meglepő, mert a párt listán mindössze 8793 szavazatot kapott. Csak összevetésképpen: az akkor már parlamenti pártként múködő LMP összesen 95 fô delegáltat tudott hadrendbe állítani ekkor. Az LMP mellesleg azért nem szerepel a vizsgálatomban, mert a párt nem tudott értelmezhető mértékú delegáltat felmutatni egyetlen választási esemény alkalmával sem.

Ahogy korábban jeleztem, tanulságos következtetéseket vonhatunk le, ha a fentieket kormány - ellenzék felosztásban vizsgáljuk meg, illetve ennek kapcsán kiemelten foglalkozunk azokkal a szavazókörökkel, ahol csak a Fidesz tudott pártdelegáltat mozgósítani.

A Fidesz példátlan hatékonysággal tudta megszervezni a szavazókörök felügyeletét, szinte alig találunk olyan választási eseményt és településkategóriát, ahol ne lett volna a mozgósítási hatékonyságuk $90 \%$ feletti. Ezzel szemben az ellenzék pártjai, lényegében a településhierarchia alacsonyabb fokai felé haladva, fokozatosan kopnak ki a szavazókörökből, habár például 2018-ban számos debreceni vagy székesfehérvári szavazókörnek sem volt ellenzéki biztosa. Ez a településméretből fakadó differenciáltság és térvesztés a 2019-es EP választás során volt a legszembetűnőbb, hiszen szervezetileg pont az a Jobbik roppant meg ekkorra, amely addig a kisebb településeken sok esetben egyedül képviselte az ellenzéket a szavazókörökben.

A delegálási potenciált vizsgáló kormány - ellenzék felosztásban tehát a településméretnek döntő jelentősége van, ami arra enged következtetni, hogy az ellenzéki pártok szervezeti fejletlensége pont a legkisebb településeken a leginkább tetten érhető. Említést érdemel, hogy van két másik mutató, amely választásról választásra ismétlődően, a településmérettel fordítottan arányosan nő; a Fidesz-KDNP pártlistás támogatottságának aránya, illetve a rontott szavazatok aránya. Előbbi jelenség már a 2002-es országgyűlési választásokon is jól látható volt, ami elsősorban az egykori FKGP szavazóbázis integrálásával magyarázható, utóbbira azonban nem tudok hasonló egzakt tudományos magyarázattal szolgálni. Ha elfogadjuk azt a feltevést, amelyre a tanulmány bevezetőjében is utaltam, mely szerint egy párt sikerének titka a helyi (fizikai) jelenlét, mely testet ölthet párttagokban, aktivistákban, helyi pártirodákban, akkor kézenfekvő a magyarázat, hogy a Fidesz-KDNP sikereit összekapcsoljuk a helyi pártdelegáltak szinte minden településre kiterjedő jelenlétével. 


\section{A helyi pártjelenlét és a választási eredmények közötti összefüggés}

Ha a vizsgált pártok eredményességét (listás szavazatarány) az alkalmazott településméret szerinti bontásban elemezzük, érdemes külön kezelnünk azon szavazókörök eredményeit, amelyekben az adott pártnak volt szavazatszámláló delegáltja. Ezzel szeretném empirikusan bizonyítani a helyi pártjelenlét és eredményesebb választási szereplés ok-okozati összefüggését. A szavazókörök nem szigetszerűen létező, önmagukban értelmezhető területi egységek, csupán egy választásról választásra életre hívott választástechnikai konstrukció. Természetesen egy ilyen vizsgálati megközelítés elsősorban a legkisebb, egy szavazókörrel rendelkező településekről adhatja a legreprezentatívabb képet, hiszen a választási eljárásról szóló törvény értelmében egy szavazókörre mintegy hatszáz, legfeljebb ezerötszáz, a központi névjegyzékben szereplő választópolgár juthat (2013. évi XXXVI. törvény a választási eljárásról 77. § (1)). Ennek megfelelően hazánk közel 1500 települése ún. egy szavazókörös község, így a szavazóköri szintú választási adatok, ebben az esetben a települési szintet is bemutatják.

A baloldali pártok esetében megállapítható, hogy minimális mértékben ugyan, de minden vizsgált választás alkalmával az összes településkategóriában jobban szerepeltek a „delegált” szavazókörökben, mint az adott településkategória összesített eredményei. Mindazonáltal, ezek valóban nagyon alacsony, rendre 1-2 százalékpont körüli vagy az alatti értékek. Nagyobb differenciáltságot csak a legkisebb népességú, így rendkívül alacsony elemszámú településkategóriák esetében tapasztalhatunk. A Demokratikus Koalíció esetében egy árnyalatnyival erősebben kirajzolódik a delegálttal rendelkező és összesített szavazóköri eredményeinek különbsége, ugyanakkor érdemes még egyszer hangsúlyozni, hogy a DK feleannyi szavazókörben sem tudott országosan pártjelenlétet biztosítani, mint a szocialisták.

A Jobbik esetében pontosan ugyanezt a megállapítást tehetjük; minden vizsgált választási esemény alkalmával eredményesebb volt saját maga településkategóriákon belüli értékeihez viszonyítva. A delegált és összesített adatok közötti eltérések ez esetben is minimálisak (1\% alattiak), azonban a pártdelegálttal rendelkező szavazókörök rendre kedvezőbb eredményeket hoztak a pártnak.

A kormánypártok esetében hasonló vizsgálat lefolytatását okafogyottá tette a 95-99\% körüli szavazóköri delegálási teljesítmény, így itt egy másik egyszerú eljárást alkalmaztam. Azon szavazókörök eredményeit külön elemeztem, ahol (a helyi választási bizottság tagjain kívül) kizárólag a kormánypártoknak ültek delegáltjai. Az összes magyarországi szavazókör 8,8\%-át jelentette ez 2014-ben (országgyúlési választások), 2018-ban már 12\%-ot, de az EP voksolások alkalmával pedig ez a szám jóval magasabb volt (2014: 21\%, 2019: 26\%). Ha ezen klaszter tagjait hasonló településméret kategóriákban vizsgáljuk, láthatjuk, hogy minden választási eseményen, az összes vizsgált település kategóriában a Fidesz-KDNP listás eredménye átlagosan 4-5 százalékponttal magasabb volt, mint az adott választáson az adott településkategórián belül mért eredmény (3. táblázat).

Ez alól egyetlen kivétel a 2014-es EP választások fővárosi adata, ahol minimálisan ugyan, de rosszabbul szerepelt a Fidesz-KDNP lista a pártdelegáltakkal rendelkező szavazókörökben. A szavazóköri pártdelegáltak adatait a 106 OEVK szintjére aggregálva is megállapítható az egyes pártok delegálóképességének markáns területi jellege, ami természetesen következik a fentebb bemutatott településméretből fakadó jellegzetességekből is. Az egyszerú Pearson korreláció adataiból próbáltam érzékeltetni a két OEVK szintû változó (listás szavazat \%, a szavazókörök hány \%-ában volt jelen az adott párt) közötti összefüggés erósséget (4. táblázat). 
A Fidesz-KDNP listás szavazataránya (\%) településtípusonként, valamint azokban a szavazókörökben, ahol csak a párt delegáltja foglalt helyet („csak Fidesz”).

The Fidesz-KDNP list vote share (\%) by type of settlement and in constituencies where only the party delegate was seated (,Fidesz only”).

\begin{tabular}{c|ccc|c|c|c|c|c}
\hline & \multicolumn{2}{|c|}{$\mathbf{2 0 1 4}$ EP } & \multicolumn{2}{|c|}{$\mathbf{2 0 1 9}$ EP } & \multicolumn{2}{c}{$\mathbf{2 0 1 4}$} & \multicolumn{2}{c}{$\mathbf{2 0 1 8}$} \\
& csak & orszá- & csak & orszá- & \multicolumn{2}{c}{ csak } & orszá- & \multicolumn{2}{c}{ csak } & orszá- \\
& Fidesz & gos & Fidesz & gos & Fidesz & gos & Fidesz & gos \\
\hline Budapest & 43,0 & 43,7 & 42,2 & 41,0 & 39,4 & 38,5 & 39,4 & 38,1 \\
$20000-*$ & 51,1 & 48,9 & 51,3 & 48,2 & 46,6 & 40,3 & 47,6 & 43,6 \\
$10000-20000$ & 58,8 & 52,9 & 54,9 & 52,8 & 51,6 & 44,0 & 52,5 & 47,3 \\
$5000-10000$ & 58,8 & 56,0 & 58,6 & 56,2 & 51,6 & 46,5 & 55,2 & 51,6 \\
$1000-5000$ & 60,8 & 57,8 & 62,0 & 59,4 & 53,1 & 48,2 & 57,5 & 54,6 \\
$500-1000$ & 62,6 & 60,7 & 65,9 & 63,5 & 54,5 & 50,8 & 60,6 & 58,3 \\
-500 & 64,1 & 62,5 & 67,5 & 65,4 & 56,7 & 53,4 & 63,8 & 61,2 \\
Magyarország & $\mathbf{5 9 , 7}$ & $\mathbf{5 1 , 5}$ & $\mathbf{6 0 , 9}$ & $\mathbf{5 1 , 9}$ & $\mathbf{5 2 , 2}$ & $\mathbf{4 3 , 5}$ & $\mathbf{5 6 , 1}$ & $\mathbf{4 7 , 4}$ \\
\hline
\end{tabular}

* Budapest nélkül

Forrás: NVI, saját szerkesztés

Source: NVI, own compilation

4. táblázat - Table 4

Pearson korreláció: Az egyes pártok listás támogatottsága (\%) és a pártdelegálttal rendelkező szavazókörök aránya az OEVK összes szavazókörén belül (\%).

Pearson correlation: List support for each party (\%) and the share of constituencies with party delegates in the total constituencies of the OEVK $(\%)$.

\begin{tabular}{|c|c|c|c|c|}
\hline & csak Fidesz & Jobbik & MSZP & DK \\
\hline 2014 országgyúlési & 0,37 & $-0,04$ & \multicolumn{2}{|c|}{0,33} \\
\hline $2014 \mathrm{EP}$ & 0,58 & $-0,14$ & 0,14 & 0,41 \\
\hline 2018 országgyưlési & 0,45 & 0,21 & 0,45 & 0,58 \\
\hline $2019 \mathrm{EP}$ & 0,70 & 0,36 & 0,57 & 0,59 \\
\hline
\end{tabular}

Forrás: NVI, saját szerkesztés

Source: NVI, own compilation

A Fidesz-KDNP esetében a korábbiakhoz hasonlóan ez esetben is azoknak a szavazóköröknek a százalékos értékét vettem alapul, ahol kizárólag a kormánypárt delegáltjai voltak jelen. Az ő esetükben találjuk a legerősebb összefüggést, ez a 2019-es EP választások kapcsán (0.7) volt merhető. Ugyebár ekkor volt a legmagasabb azon szavazókörök száma országosan, ahová csak a Fidesz-KDNP volt képes delegálni (több mint minden negyedik szavazókör tartozott ebbe a csoportba ekkor). A Jobbik esetében is csak a legutóbbi EP voksolás kapcsán kapunk értelmezhető eredményt, amikorra már a párt által felügyelt szavazókörök száma országosan 28\%-ra zsugorodott. Ezzel szemben a baloldal pártjainál egy fokozatosan erősödő összefüggést tapasztalhatunk, habár a mért értékek még 
korántsem magyarázó erősségűek. Érdemes azt is rögzíteni, hogy a szocialisták abszolút számban szinte választásról választásra 5 ezer szavazókörben voltak képesek megjelenni, addig a DK egy nagyon komoly bővülésén ment keresztül szervezetileg ezen a téren (is). A Demokratikus Koalíció esetében megállapítható, hogy azokban az EOVK-kban szerepeltek átlagon felül, ahol szavazatszámláló biztosuk volt, így vélelmezhetőleg kiépült pártszervezettel is rendelkeztek 2019-re.

A kormánypártok 2-3 dél-dunántúli OEVK-t leszámítva (Baranya 3 - Mohács, Baranya 4 - Szigetvár, valamint Somogy 3 - Marcali) minden választókerületben legalább a szavazókörök 90\%-ában jelen tudtak lenni a választásokon. A Fidesz-KDNP szervezeti hatékonysága tehát ezen a vizsgálati szinten is egészen kimagasló, és csak az ország bizonyos térségeiben volt megközelíthető az ellenzéki pártok számára.

A négy választási esemény adatainak vizsgálata után kijelenthető, hogy az ellenzék pártjainak számára a legnagyobb akadályt a Dunántúlon, de azon belül is kifejezetten a Nyugat-Dunántúl választókerületeiben való megjelenés jelentette. A Jobbik esetében közismert volt a párt kelet-magyarországi meghatározottsága, illetve annak nehézsége, hogy a nem kifejezetten válságtérségnek számító nyugati határszélen is eredményesen építkezzen (RónA D. 2017; TöLGYESSY P. 2015) (1. ábra).
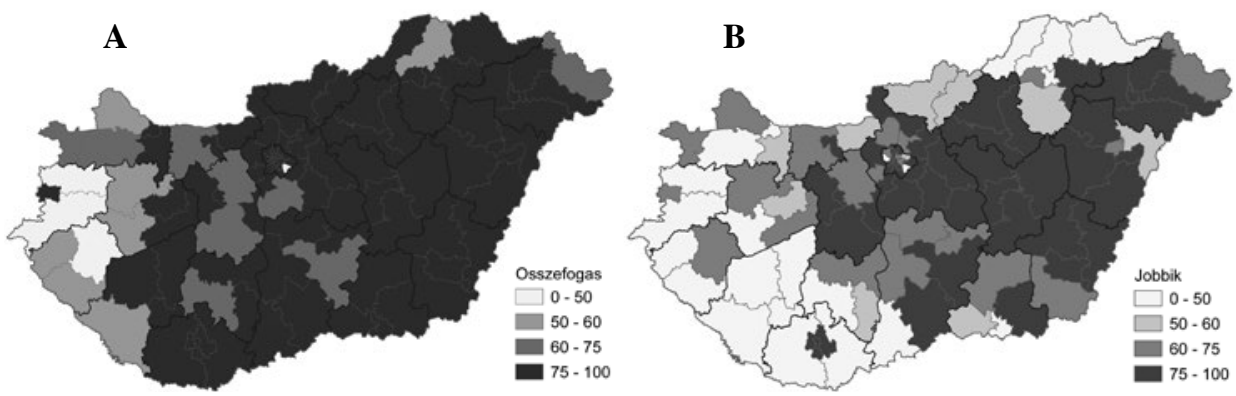

1. ábra Az Összefogás (A) és a Jobbik (B) delegáltjai az OEVK szavazóköreinek \%-ában a 2014-es országgyúlési választásokon. Forrás: NVI, saját szerkesztés.

Figure 1 Összefogás (A) and Jobbik (B) delegates in \% of the electoral districts of the OEVK in the 2014 parliamentary elections. Source: NVI, own editing.

A 2014-es országgyúlési választás alkalmával a szigetszerűen kiemelkedő szombathelyi és győri OEVK-t leszámítva a legtöbb nyugat-dunántúli választókerületben alig több, mint a szavazókörök 60\%-ban tudtak delegáltat küldeni. Ezzel szemben a Dunától keletre nagyon jó hatékonysággal tudták ezt a logisztikai feladatot megoldani a csereháti, gömöri aprófalvas térséget is magába foglaló Borsod-Abaúj-Zemplén megye 4-es OEVK-t leszámítva. 2018-ra ez a kép a baloldali pártok esetében jelentősen megváltozott, és azon választókerületek, amelyek szavazóköreinek legalább háromnegyedében ott tudtak lenni az MSZP delegáltjai, a megyeszékhelyek, valamint az Alföld központi részére szorultak vissza. A 2014-es baloldali összefogás másik pártja, a DK jóval kevesebb biztost delegált ekkor, és azok 40\%-a is Budapest szavazóhelyiségében foglalt helyet. OEVK szinten tehát elsósorban a fővárosban és annak agglomerációjában, valamint a Dunakanyar, illetve megyeközpontok választókerületeiben voltak jelen jelentősebb számban.

Jobbik a 2014-es országgyúlési választások alkalmával szintén az Alföld központi részein tudott a legeredményesebben mozgósítani a pártdelegáltakat, de ezen felül is elsôsorban Kelet-Magyarország egyéb területein volt hatékony (2.ábra). Heves és Jász-NagykunSzolnok megyék összes választókerületében, legalább a szavazókörök háromnegyedében jelen volt a párt, de hasonló hatékonyság jellemezte ôket Békés és Szabolcs megyék majd- 
nem összes körzetében is. Ez a magterület jelentős átfedésben áll azzal a „Jobbik bázis” klaszterként hivatkozott térséggel, amit a korábban citált választási földrajzi tanulmányok, a választási eredmények alapján beazonosítottak (VIDA Gy.-KovÁCs Z. 2017. illetve VIDA Gy.-KovalcsiK T. 2018). 2018-ra ez a térszerkezet nem módosult jelentősen a Jobbik esetében. Több dunántúli területen felsejlik a párt eredményes szervezetépítése (pl. Somogy és Fejér megye), mindazonáltal a Jobbik kapcsán is megállapítható, hogy Nyugat-Dunántúlon az egyik vizsgált időpontban sem tudtak eredményesen delegálni.
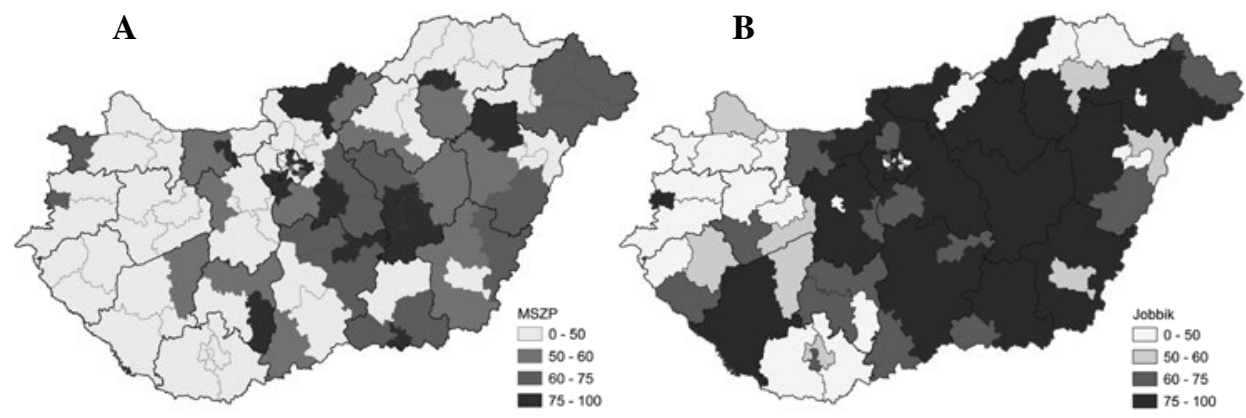

2. ábra Az MSZP (A) és a Jobbik (B) delegáltjai az OEVK szavazóköreinek \%-ában a 2018-es országgyúlési választásokon. Forrás: NVI. saját szerkesztés.

Figure 2 MSZP (A) and Jobbik (B) delegates in \% of OEVK constituencies in the 2018 parliamentary elections. Source: NVI. own editing.

Mintegy a fentiek eredőjeként aligha meglepő, hogy a csak Fidesz-KDNP által „felügyelt" szavazókörök százalékos aránya az egyes OEVK-kon belül pont a Nyugat-Dunántúl régiójában a legkirívóbb (3. ábra). Mindkét vizsgált országgyúlési választás esetén a Vas megye 2-es és 3-as OEVK-k voltak azok, amelyekben a szavazókörök több mint felében csak a kormánypárt rendelkezett pártdelegálttal. A szombathelyi OEVK-t leszámítva, szinte az összes ezekkel határos választókerületben is relatív magas ezen szavazókörök aránya (25-50\%). A 2018-as választások idejére nem módosul jelentősen ez a térszerkezet, azonban számos alföldi OEVK is „,csatlakozik” a relatíve magas, kizárólag a kormánypártok által delegált szavazókörökkel rendelkezők csoportjához. Mindkét vizsgált időpontban, Északkelet-Magyarország aprófalvas választókerületében is viszonylag magas volt a csak Fidesz delegálttal rendelkező szavazókörök aránya.

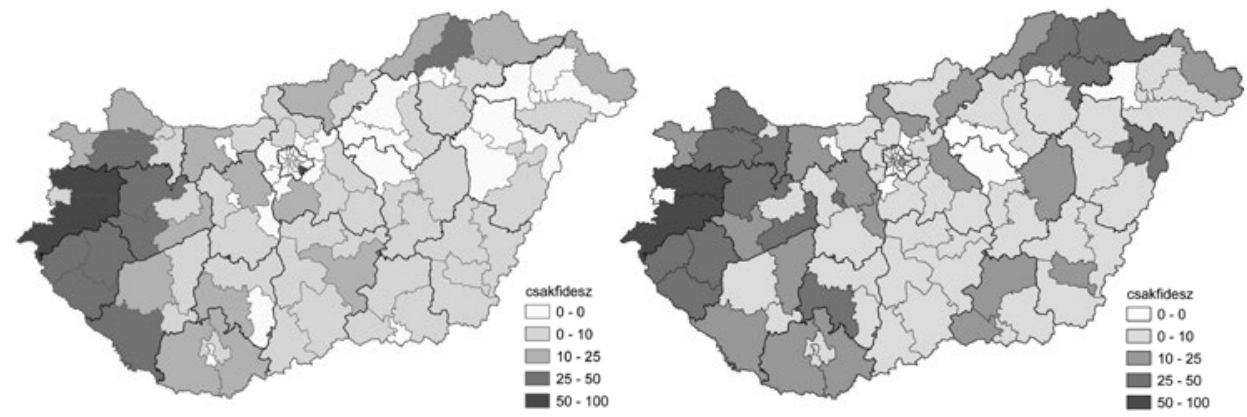

3. ábra A csak Fidesz-KDNP által delegált szavazókörök arány (\%) az OEVK összes szavazókörén belül, a 2014-es és 2018-as országgyúlési választásokon. Forrás: NVI, saját szerkesztés.

Figure 3 The proportion of Fidesz-KDNP-only constituencies (\%) within the total constituencies of the OEVK in the 2014 and 2018 parliamentary elections. Source: NVI, own editing. 


\section{Összefoglalás}

Vizsgálatom elsődleges célja, a hazánk politikai színterét meghatározó pártok, szervezeti fejlettsége területi különbségeinek feltárása volt. Azok a korábbi nemzetközi kutatások, melyek a magyar pártosodás folyamatát, valamely kvantitatív módszer felhasználásával kívánták, a térség poszt-szocialista országainak kontextusában vizsgálni, rendre az adathiány akadályába ütköztek. Ennek egyik oka a hazai pártrendszer viszonylagos fejlettlensége, ami a párttagok és alapszervezetek relatív alacsony számában fejeződik ki (Riberio P.F.-LOCATElli F. 2019), továbbá maguk a pártok sem szeretnek ilyen jellegú adatokat közölni, ami szintén nem magyar, sokkal inkább térségi kulturális sajátosság (TAVITS M. 2012). Annak megértése, hogy pártjaink Magyarország egyes vidékein, eltérő mértékú társadalmi beágyazottságra tettek szert, azért is fontos, mert számos fentebb idézett nemzetközi példa mutatja, hogy a sikeres választási szereplés alapfeltétele (nem kizárólagosan ugyan) a helyi jelenlét, pártszervezet megléte. A politikai élet szereplői mindazonáltal akkor lesznek képesek szélesebb választói rétegek számára releváns társadalmi problémákra érdemben reagálni, ha az ország minden vidékére rálátó szervezeti struktúrával rendelkeznek.

Ebben a tanulmányban a pártok társadalmi beágyazottságát a négy vizsgált országos jelentőségú választás során a szavazókörökbe delegált biztosok adatain keresztül próbáltam kitapintani. A kormányoldal hatékonysága (szavazókörök 95-99\%-a) választásról választásra oly mértékben kiemelkedő, hogy gyakorlatilag alig enged teret bármiféle érdemi területi vizsgálatnak. Így ezzel a politikai szereplővel kapcsolatban annyit állapíthatunk meg, hogy településmérettôl és a választókerület földrajzi elhelyezkedésétől függetlenül, a társadalom minden rétegében jelen van egy nagyon hatékony pártszervezettel. A választási eredmények összevetését ezért azokra a szavazókörökre szúkítettem, ahol kizárólag a Fidesz-KDNP delegáltjai voltak jelen. Ebben a szegmensben a párt még a saját maga az adott településtípuson belül mért eredményeit is képes volt átlagosan 4-5\%-ponttal meghaladni, ami jól mutatja a kiépült pártszervezeti háló fontosságát.

Ellenzéki oldalon már egy jóval differenciáltabb képet láthattunk. Ennek van egy horizontális, a településméretből fakadó vetülete is, mely szerint a települési hierarchián lefelé haladva egyre kisebb pártjelenlétre számíthatunk. Ez különösen igaz a baloldal pártjaira, míg a Jobbik számottevő pártszervezeti hálóval rendelkezhetett az alacsonyabb népességú településeken is. Az ellenzéki pártok választói támogatottsága is erősen eszerint a település lélekszámából fakadó dinamika mentén alakult, ugyanakkor ha kizárólag az általuk „delegált" szavazókörök adatait vesszük számításba, látható, hogy 1-2 százalékpontos többletet jelentett egy pártdelegált megléte. A Jobbik esetében érdemes kiemelni, hogy a párt kifejezetten a közepes méretú (5-20 ezer lakosú) településeken tudott hatékonyan delegálni, de a legkisebb lakosságszámú település kategóriában is számottevő delegáltat tudott felvonultatni, amire a baloldal pártjai már nem voltak képesek.

A differenciáltság másik dimenziója földrajzi természetû, amelyet OEVK szinten igyekeztem tetten érni. Âltalánosságban kijelenthető, hogy az ellenzék pártjait jóval gyengébb jelenlét jellemezte a Dunántúlon, de különösen a Nyugat-Dunántúli régióban szembetűnő szervezeti gyengeségük, ugyanakkor a perifériás elhelyezkedésú, döntően aprófalvas északkelet-magyarországi választókerületekben is feltűnőek ezek a szervezeti hiányosságok.

Összeségében megállapítható, hogy ha a szavazókörökbe delegált szavazatszámláló biztosok adatain keresztül definiáljuk a helyi pártjelenlétet, ez eképpen definiált jelenlét hozzájárul az adott párt jobb választási eredményéhez. Különösen igaz ez abban az esetben, ha kizárólag egyetlen párt delegáltja múködik egy adott szavazókörben (településen). 
Ebben az értelemben a nemzetközi szakirodalomban lefektetett hipotézis, még ha nem is túl erôsen, de bizonyítható volt empirikus úton hazánk esetében is.

Az elmúlt 15-20 év tapasztalatai azt mutatják, hogy térségünkben azok a pártok tudnak sikeresek lenni (legalábbis állva maradni a harcmezőn), akik komoly munkát fektettek a pártszervezeti háló megszövésébe (TAVITS M. 2012). Nem szabad figyelmen kívül hagyni persze a megfelelő politikai légkör meglétét sem, amely mintegy alapfeltétele, katalizátora egy számottevő és országos hatósugárú mozgalmi munkának. A Fidesz-KDNP gyakorlatilag 2006 őszétől tartó példátlan választási sikersorozatának számos összetevője ismert, illetve állandó közéleti vita tárgyát képezi. A 2002-es választási kudarc olyan energiákat szabadított fel, mely a polgári körök mozgalma és a gyakorlatilag abszolút mértékben a pártelnök kezébe adott teljhatalmú pártirányítási jogosítványokon keresztül (BÉKÉs M. 2009), egy hallatlanul hatékonyan múködő politikai-szervezeti gépezetet felépítését eredményezte. A Fidesz tehát jól ismerte fel és használta ki a 2002 utáni társadalmi felhajtóerőket és tudatos szervezetépítésbe kezdett (társszervezetek bevonásával; pl. MAGOSZ, egyházak stb.), ami sok szempontból mintaadó. A tudatos közösségépítés technikái terén (választók személyes elérésére koncentráló szervezeti háló megépítése) szintén mértékadónak mondható a magyar politikai életben az, amit a Fidesz 2003-tól kezdődően végigcsinált (BALÁZs Z.-HAJDÚ A. 2017).

A kormányon lévő politikai oldal társadalmi beágyazottságának mértéke, különösen hazánk vidéki területein, kimagasló, még ha történelmi szempontból nem is példa nélküli. Ennek kvantitatív alátámasztására meglátásom szerint kiválóan alkalmas az általam használt szavazóköri pártjelenlét.

Létezik azonban egy olyan tényező is, amelynek megemlítése nem megspórolható vizsgálatom szempontjából, ugyanakkor adatok tekintetében jóval nehezebb tetten érni. Többek szerint (KovÁCH et al. 2020) a kormányoldal sikerének egyik kulcsát azok az informális hálózatok jelentik, amelyek már nem is írhatók le azokkal a hagyományos pártos intézményesültségi kritériumokkal, melyekre az idézett nemzetközi szerzők hivatkoznak. A mai mediatizált világban, a politika ma úgy képes hatékony üzenetközvetítésre a választók felé, hogy helyi szinten nincs rászorulva a politikai integráció közvetlen lokális formáira, tehát a helyi közösségekre (lásd, polgári körök megszűnésé). A magyar, politikai értelemben is egy egyre inkább felülről integrált társadalom (HuSzÁr Á.-SzABó A. 2020.), amelyben maguk a politikai szereplők képesek azokat az identitáshordozó témákat szolgáltatni, amelyek mentén a választók pártpreferenciális döntéseket hoznak. Ez ma ugyan úgy igaz az ellenzékre, mint a Fidesz-re, csak utóbbi, itt most be nem mutatott okoknál fogva, ezt sokkal hatékonyabban tudja megtenni.

A Jobbik, a 2006 őszét követő politikai feszültség, valamint a 2008 utáni társadalmi-gazdasági krízis hullámain tudott egy szinte példátlan nagyságú vidéki pártszervezetet felépíteni és sokáig viszonylag eredményes múködtetni. Ebben persze kulcsszerepet játszott a Magyar Gárda felállítása is, de tény, hogy a pártnak 2010-re már közel ezer alapszervezete múködött országszerte (RónA D. 2017). A vizsgálatomban használt indikátort alapul véve kijelenthető, hogy a Magyar Szocialista Párt még mindig a hazai baloldal legszerteágazóbb szervezeti hálójával rendelkező pártja. Az MSZP delegáltjai nagyjából állandó számban, a hazai szavazókörök csaknem felében képviselik pártjukat. A szocialisták viszonylagos szervezeti fejlettsége, már a 2014-es választásokat megelőzően is beszédtéma volt a hazai politikai nyilvánosságban, habár ekkor már olyan nem pártos, de alapvetően a hazai progresszív vagy baloldali ideológiákat nyíltan felvállaló civil mozgalmak is szárba szökkentek, mint a Milla vagy a Szolidaritás. A későbbi választási együttmúködés megindoklásának egyik legszemléletesebb példája az alábbiak szerint volt olvasható a Magyar Narancs hasábjain 2013-ban (Magyar Narancs, 2013 március 1.) „Az MSZP és az Együtt 
2014 - Erögyüjtési szakasz”: „Az MSZP megkerülhetetlen tényező. Olyan szervezeti háttérrel rendelkezik, amilyen a baloldalon még közelitóleg sincs senkinek, és amely életfontosságú egy olyan ajtótól ajtóig zajló kampányban, mint amilyenre most számítani lehet."

A kedvező belpolitikai légkör (NOlimpia kampány és a 2019-es EP választások sikere) akár hasonló felhajtóerőként hathatott volna hazánk legújabb politikai szereplőjére, a Momentum Mozgalomra is, azonban az általam használt mutató alapján a párt szinte alig tudott vizsgálatra érdemes számú delegáltat felvonultatni a 2019-es EP választások alkalmával (313 db szavazókörben). Beszédes, hogy a párt, a delegáltjainak csaknem felét Budapesten mozgósította és mindössze 20 darab községi jogállású település szavazókörében volt jelen. Ha a szavazatszámláló biztosok adatain keresztül próbáljuk tetten érni a párt szervezeti fejlettségét, a Momentum kapcsán arra kell következtessünk, hogy még nagyon a pártinfrastruktúra kiépítésének az elején járnak, vagy szimplán az online politikai hadviselés eszközeiben bízva próbálnak meg üzeneteket eljuttatni a választókhoz. Az általam idézett nemzetközi tanulmányok egybe csengó megállapításai szerint, ez nem lesz egy hosszútávon jól kifizetődő taktika.

Térségünk pártjai, még mindig egy viszonylag fiatalnak mondható demokratikus berendezkedésben versenyeznek egymással. Azonban még a legmintaadóbb parlamentáris demokráciákban is, arra vannak kényszerítve ezek a versengő pártok, hogy folyamatosan felülvizsgálják és megújítsák azokat a gyakorlatokat, amelyek a pártszervezet fejlesztésére irányulnak (ScotT J. - WiLls J. 2017). Az idézett nemzetközi szerzők egybehangzóan állítják, hogy még a megváltozott médiafogyasztási és technológiai viszonyok mellett is, hatékony kampányokat és ezáltal jó választási eredményeket nagyon nehezen lehet elérni, egy helyben jól funkcionáló pártszervezet nélkül. Az általam elvégzett összevetésben különösen ott nyert megerősítést ez az elmélet, ahol az egyik politikai szereplő képviselete kizárólagos volt. Ha a jelenlegi kétosztatú politikai színtérre egyszerúsítjük a képletet, akkor kijelenthető, hogy ha Magyarország csak azokból a szavazokörökből állna, ahol kizárólag a Fidesz-KDNP volt képviseltetve, választásról-választásra, a kormánypártok átlagosan $8 \%$ ponttal jobb eredményt értek volna el listán. Mindeközben az ellenzéki pártok esetében, a pártdelegált jelenléte átlagosan $1 \%$ körüli szavazattöbbséget jelentett országosan. A vizsgált településkategóriákon belül is csak a baloldali pártok esetében mutatható ki ennél nagyobb többlet, jellemzően a legalacsonyabb népességú településeket tömörítő csoportokban, ahol amúgy is alacsony volt a delegált szavazókörök száma.

MARGIT TAVITS kutatási eredményeit, nem csak azért tartom fontosnak, mert annak fókuszába több poszt-szocialista ország mellett hazánk is bekerült, hanem mert figyelembe vette az önkormányzati választások pártos indulóit is (1990-2010 között). Így formai hasonlóságokat is mutat az általam használt módszertannal, abban az értelemben, hogy közvetlenül a választások során keletkező adat alapján közelíti a pártjelenlétet. Megállapítja, hogy a választókerületi szinten, ott tudtak jobb eredményt elérni a vizsgált magyar pártok (átlagosan 5\% ponttal), ahol az átlagosnál nagyobb számban voltak önkormányzati indulói. Egy hasonló kutatás időbeli kiterjesztése a 2010 utáni időszakra, ennek a vizsgálatnak is, egy ígéretesnek tûnő új iránya lehet.

Bódi MÁTYÁs

ELTE, TTK, FFI, Etnikai- és Vallásföldrajzi Mühely

bodimatyas@gmail.com 


\section{IRODALOM}

BALÁzs Z.-HAJdú A. 2017: A Fidesz - Magyar Polgári Szövetség a magyar politikában - In. Trendek a magyar politikában - 2; A Fidesz és a többiek: pártok, mozgalmak, politikák (szerk BoDA Zs.-SzABó A.), MTA TK Politikatudományi Intézet, pp. 83-109.

BASEDAU M.-STROH. A. 2008: Measuring Party Institutionalization in Developing Countries: A New Research Instrument Applied to 28 African Political Parties - GIGA (German Institute of Global and Area Studies) - Working Papers, 69. pp. 1-28.

BÉKÉs M. 2009: Pártirányítás - Irányított párt: A Fidesz szervezeti változásainak hatása a párt centralizációjára (1988-2008). TDK-dolgozat. Budapest: Budapesti Corvinus Egyetem.

Bódi F.-Bódi M. 2011: Hol vannak a választók? - Politikatudományi Szemle, 20. 1. pp. 51-74.

EBESZ/ODIHR 2014: Limited Election Observation Mission Final Report: Parliamentary Elections 6 April 2014 in Hungary, 32 p.

EBESZ/ODIHR 2018: Limited Election Observation Mission Final Report: Parliamentary Elections 8 April 2018 in Hungary, 33 p.

ENYEDI Zs.-KÖRÖSÉNYI A. 2001: Pártok és pártrendszerek. - Osiris Kiadó, Budapest 304 p.

ENYEDI Zs. 2004: A voluntarizmus tere. A pártok szerepe a törésvonalak kialakulásában. - Századvég (Új Folyam) 33. pp. 5-26.

Frendreis, J. P.-Gibson J L.-Laura L. V. 1990. „The Electoral Relevance of Local Party Organizations.” American Political Science Review 84. 1. pp. 225-235.

GERGHINA S. 2014: Shaping parties' legitimacy: Internal regulations and membership organisations in post-communist Europe - In. International Political Science Review / Revue internationale de science politique, 35. 3. pp. 291-306.

HAJDÚ Z. 2006: A 20. századi magyar parlamenti választások választási földrajzi kérdései - Múltunk, $2006 / 1$. pp. 137-169.

HALVORSEN S. 2020: The geography of political parties: Territory and organisational strategies in Buenos Aires - Transaction of the Institute of the British Geographers, 2020, 45. 2. pp. 242-255.

Huszár Á.-SzABÓ A. 2020: Pártszimpátia és a társadalmi mobilitás érzékelése. In. KovÁcH I. 2021: Mobilitás és integráció a magyar társadalomban. Társadalomtudományi Kutatóközpont - Argumentum Tudományos Kiadó, Budapest, pp. 11-34.

JANKÓ F.-KOMORNOKI M. 2008: Szuburbanizáció és választási földrajz: átalakuló pártválasztás Budapest térségében - Tér és Társadalom 22.4. pp. 115-134.

KÁKAI L.-VETô B. 2019: Állam vagy/és Önkormányzat - Adalékok az önkormányzati rendszer átalakításához. - Politikatudományi Szemle 28. 1. pp. 17-41.

KovÁcH I. 2021: Mobilitás és integráció a magyar társadalomban. Társadalomtudományi Kutatóközpont - Argumentum Tudományos Kiadó, Budapest, 371 p.

KovÁCs Z. 1991: Az 1990. évi parlamenti választások politikai földrajzi tapasztalatai - Földrajzi Értesítő, 40. 1-2. pp. pp. 55-80.

KÖRÖSÉNYI A.-GYULAI A.-ILlÉs G. 2020: Az Orbán-rezsim - A plebiszciter vezérdemokrácia elmélete és gyakorlata. - OSIRIS Kiadó, Budapest, 256 p.

LAKNER Z. 2017: Megújuló válság. Az MSZP alkalmazkodási kísérlete 2010 után - In. Trendek a magyar politikában - 2; A Fidesz és a többiek: pártok, mozgalmak, politikák (szerk. BodA Zs.-SzABó A.), MTA TK Politikatudományi Intézet, pp. 143-167.

LÁszLó R. 2018: Nem hozott a külhon mandátumot a Fidesznek, a „győzteskompenzációval” együtt viszont 7-et is - In. Választásirendszer.hu http://www.valasztasirendszer.hu/?p=1943608\&fbclid=IwAR0y_Hq4tOrZanWhZOvlNvI5gRsz-DpRsmpl_ X670zF4Lccj71-v7f3Aj8s

Mikola B.-Oross D. 2018: Egy pártszervezet két arca. A mozgalmi pártok belső feszültségei az Öt Csillag Mozgalom példáján keresztül - In. Politikatudományi Szemle, 2018. 27. 1. pp. 65-90.

PeTE M. 2016: Határképző identitások - identitást képző határok. - Földrajzi Közlemények.pp. 296 -311.

PÁLné KovÁcs I. 2019: Az önkormányzati választások elé - In. Karátson Gábor Kör előadása: 2019. október 11. https://okopolitika.hu/szabadegyetem/36-az-onkormanyzati-valasztasok-ele

RiBERIO P. F. - LOCATELLI F. 2019: Time after time: party organizational strength in new and old democracies. - Opin. Publica 2019. 25. 1. pp. 23-32.

RónA D. 2016: Jobbik-jelenség. A Jobbik Magyarországért Mozgalom térnyerésének okai. - KUK Könyv és Kávé Kiadó, Budapest 314 p.

SCHIFFER A. 2018: „Gyurcsány Ferenc egyetlen igazsága” - In: ScHIFER A.: Zöld Jelzés, Kaligram Kiadó, Budapest, pp. 402-404.

SCOTT J.-WILLS J. 2017: The geography of the political party: Lessons from the British Labour Party's experiment with community organising, 2010 to 2015 - Political Geography, 2017, 60. 3. pp. 121-131. 
STUMPF A. 2021: Így nyerne a Fidesz Budapest nélkül - a vidéki pénzszórás háttere. Válasz Online: https://www.valaszonline.hu/2021/01/21/fidesz-ellenzek-valasztas-videk-lazar-janos-csanyi-sandor/

SzIGETI P. 2013: A magyar választási rendszer átalakítása - összehasonlítható - Jogtudományi Közlöny, 69. 2. pp. 82-92.

Tavits M. 2012: Post-Communist Democracies and Party Organization. - Cambridge University Press, New York, $241 \mathrm{p}$.

Tavits M. 2014: Post-Communist Democracies and Party Organization - In. Journal of Politics, 76. 3. 2014. pp. $1-22$.

TóKA G. 1991: „Választási eredmények elemzése.” - In: Hol tart a szabad gondolat? Szerk. GYEKICZKI ANDRÁS. Budapest: Politikai Tanulmányok Intézete, pp. 65-92.

Tóтн Cs. 2017: Választási rendszer és választások 2014-ben - In. Trendek a magyar politikában - 2; A Fidesz és a többiek: pártok, mozgalmak, politikák (szerk BoDA Zs.-SzABó A.), MTA TK Politikatudományi Intézet, pp. 43-60.

TÖLGYESSY P. 2015: A magyar társadalom válságának újabb stációja - In. Ökopolisz Alapítvány: https://www.youtube.com/watch?v=vck01u7rpWM

TÖLGYESSY P. 2019: „Mára a '89-es példakép is bajba került” - Ellensúly Közéleti Folyóirat, Budapest, 4. 3. pp. $4-27$.

TÖRÖK G. 2019: Török Gábor politikai elemző az InfoRádió Aréna címú músorában 2019. október 14-én: https://www.youtube.com/watch?v=vUqCpHI8fsQ

VIDA GY.-KovÁCS Z. 2017: Magyarország átalakuló választási földrajza a 2010-es és a 2014-es parlamenti választások tükrében. - Földrajzi Közlemények 141.2. pp. 125-138.

VIDA Gy.-KovalcsiK T. 2018: Magyarország választási földrajzi sajátosságai a 2014-es és a 2018-as parlamenti választások tükrében. - Modern Geográfia, 13.4. pp. 15-30.

VIDA GY. 2020: A magyar országgyűlési választási rendszer földrajzi torzulásainak vizsgálata - Doktori (PhD) értekezés, Szegedi Tudományegyetem Természettudományi és Informatikai Kar Földtudományok Doktori Iskola Gazdaság- és Társadalomföldrajz Tanszék, 127.p. 


\title{
NAGYDOBRONY ÉS A NAGYDOBRONYI VADVÉDELMI REZERVÁTUM (KÁRPÁTALJA) \\ FÖLDRAJZINÉV-TÁRÁNAK ELKÉSZÍTÉSE ÉS ÁBRÁZOLÁSA TÖRTÉNETI TÉRKÉPEK ALAPJÁN
}

\author{
KOHUT ERZSÉBET - BENEDEK ANETT - HADNAGY ISTVÁN \\ GEOINFORMATIC ANALYSIS AND \\ REPRESENTATION OF THE GEOGRAPHICAL NAMES OF VELYKA DOBRON \\ AND THE WILDLIFE RESERVE OF \\ VELYKA DOBRON (TRANSCARPATHIA) BASED ON HISTORICAL MAPS
}

\begin{abstract}
The Wildlife Reserve of Velyka Dobron - which is located next to the village of Velyka Dobron (Hungarian: Nagydobrony), the fourth most populous Hungarian community in Transcarpathiais the third-largest protected reserve of national importance in the country. We used a Geographic Information System to process and map the historical geographical place names of the settlement and the protected area (pieces of land within the cadastral boundaries but located either outside the settlement boundary or on its outskirts) based on the 1st, 2nd and 3rd military surveys, a cadastral map dating back to 1865 and the documents available in the Beregszász branch of the State Archives of Transcarpathian Oblast (fonds 125, description 6, file 344), as well as literary materials. As a result, a database comprising a list of 57 place names of the area was compiled. Likewise, a map of the pieces of land within the former cadastral boundaries and in the Nagydobron' Wildlife Reserve was made. Analysis of forest area and land use changes showed that 16 pieces of land within the cadastral boundaries, but located either outside the settlement boundary or on its outskirts, have completely lost their former nature and as a result became part of the inner area of the settlement. Consequently, the compiled database and maps may help to specify the location of the ongoing research and clarify the accurate place of the earlier studies.
\end{abstract}

Keywords: geographical gazetteer, cadastral map, Velyka Dobron, Wildlife Reserve of Velyka Dobron (WRVD), Transcarpathia

\section{Bevezetés}

A névtannak, mind a személynév, mind a földrajzi név kutatásának, a névtárak létrehozásának - a Kárpát-medencén belül is - hatalmas irodalma van (LőRINCZE L. 1947; KISS L. 1980; JuHÁsz D. 1988; BíRó F. 1997; KISs L. 1999; FARAGó I. 2005; SEBESTYÉn Zs. 2010; GÁBRIS GY. 2019), amelyet a természettudomány nem alkalmaz kellóképpen. A hagyományos földrajzi nevek, tájnevek, helynevek nagy része több száz éves múltra tekint vissza (FARAGÓ I. 2016). Eredetük legtöbb esetben természetes, múvi hatásoktól mentes, az egyes tájak, települések és határrészek természeti, gazdálkodási, történeti jegyei alapján keletkeztek. Éppen ezért az ilyen névtárak segítségével, a névváltozások nyomon követésén keresztül sokféle információ szerezhető be, amit több tudományterület: földrajz, történeti ökológia, természetvédelem, erdőgazdálkodás, környezeti nevelés, névtörténet, tájtörténet, néprajz stb. is felhasználhat. Emellett nem elhanyagolható szempont az sem, hogy a hagyományos helynevek, határ- és dűlőnevek eredeti helyükön való megőrzése épp annyira fontos, mint a természeti értékek, múemlékek megvédése, a folklór értékeinek ápolása (GÁBRIEL A. 1991).

A helynevek gyújtésével Kárpátalján is leginkább történészek (LEHOCZKY T. 19811882/1996; Botlik J.-DupKa Gy. 1993), nyelvészek (Bíró A. 1993; Beregszászi A. 1998; MizSER L. 2004; KovÁCs A. 2008; SEbestyén Zs. 2003, 2008a, b, 2015, 2016a, b) 
és geográfusok (Molnár J.-MolnÁR D. I. 2005; MolnÁR D. I. 2014) foglalkoznak. Nagydobrony és környéke földrajzi neveirôl a legtöbb információt SEBESTYÉN Zs. (2003, 2008a, 2010, 2015) és MiZSER L. (1995, 1996, 2004) munkáiban találjuk. SEBESTYÉN Zs. (2003, 2008a) Kárpátalja településeinek helyneveivel foglalkozott, 476 település helynevét közli a Kárpátaljai Területi Âllami Levéltár beregszászi fiókjában megtalálható kataszteri térképekről, birtokrészleti jegyzőkönyvekből, illetve határjárásokból származó adatok alapján. Ebben Nagydobronyra 1863-ból, 1865-ból és 1908-ból származó névanyagot közöl. Az 1865-ös névanyag kataszteri térképek alapján készült, míg az 1863-as és 1908-as adatok forrása birtokrészleti jegyzőkönyv. Valamennyi adat a 125. fond 1. opiszából a 661., 654., 662., 655., 656. számú iratcsomókból származik. Különös jelentőséggel bír Pesty Frigyes helységnévtára (1864-1865) is, amelyből Bereg megyei helységneveket MizSER L. (1995) adott közre magyarázatokkal. Az 1865-ben készült múben az akkor Nagydobrony határában megtalálható összesen 113 dưló és egyéb földrajzi név szerepel, a területre jellemző rövid leírásokkal. MIzSER L. (1966) a Nagydobrony határában folyó Latorca ősvízrajzával és ártéri gazdálkodásával foglalkozó munkájából is számos információt tudhatunk meg a környék földrajzi, határ- és dûlőneveiről.

A munka célja a kárpátaljai Nagydobrony község és a Nagydobronyi Vadvédelmi Rezervátum (NVR) területéhez tartozó földrajzi, határ-, valamint dúlőnevek egységesített névtárának és digitalizált térképének elkészítése. Jelen tanulmány nem névtudományi jellegú munka; bár hasonló módszereket alkalmaz, de nem célja a létrehozott névadattár nyelvészeti vizsgálata. A munkával új utat keresünk, olyan névtárat készítünk, amely Kárpátalja egyik legnagyobb magyarlakta települése (Molnár J.-MolnÁR D. I. 2005), Nagydobrony és a mellette elterülő NVR helynévanyagát gyújti össze és térképen ábrázolja. Ezt többek között az is indokolja, hogy mind a helybéli (KoHUT E. et al. 2006, 2007; KISH, R. et al. 2006, 2009; Prots, B. 2010; Kohut, E. 2013; KolozSVÁri, I. et al. 2015a, b; SZANYi Sz. et al. 2015a, b, c, 2016; Demeter, L. 2013, 2016; SheVera, M. et al. 2017; KoHUt E. et al. 2017, 2019), mind a magyarországi (MAGURA, T. et al. 1997; DELI I.-SüMEGi P. 1999; MAGURA, T.-KÖDÖBÖCZ, V. 2005) és más határon túli (NovÁK, P. et al. 2017) kutatók figyelme ráirányult Kárpátalja alföldi régiójának természeti értékeire. Segítségével megvalósítható a már itt folyó vagy elvégzett kutatások helyének (táj- és dűlőneveinek) pontosítása, illetve egyértelműsítése.

További megerôsítést találtunk UNGVÁRY R. (2016) tanulmányában, amelyben a szerző rávilágít arra, hogy az interneten elérhető magyar nemzeti névtár és névtárak kialakításával a határon túli magyar nyelvhasználat jelentős kulturális, nem utolsósorban nyelvpolitikai támaszt kap. Megállapítja, hogy jelenleg nincs átjárás sem a földrajzi nevekkel foglalkozó térképészeti, sem a nevekkel foglalkozó nyelvészeti szakterületek között. Mi ezt az átjárhatóságot ki szeretnénk terjeszteni más tudományterületek irányába is. Reményeink szerint az elkészült munka eredményeit alkalmazni tudják majd nemcsak a NVR és környékét kutató nyelvészek, természettudósok és környezeti nevelők is.

\section{Módszertani háttér}

\section{A vizsgált terület bemutatása}

Nagydobrony Árpád-kori település, 1248-tól Dobron, Dobrun néven kerül említésre. A falu életében mindig fontos szerepet játszott az erdő. Erre utalnak a történeti adatok is (LEHOCZKY, T. 1881-1882/1996). 1638-ban Melith György törvénykezett a csongori (csomonyai) és nagydobronyi erdők határával kapcsolatban. Később Rákóczi György is vizsgálatot indított az erdők használatát illetôen (MóRICZ K. 1993). Ezen erdők maradványai a község 
határában most is fellelhetők. A Dobrony helységnév magyar eredetű, puszta személynévből keletkezett magyar névadással. Az alapjául szolgáló személynév szláv, valószínúleg a szláv dobъ „tölgy” származéka (SEBESTYÉN Zs. 2008a). A település és környéke az 1919-es Párizs környéki békeszerződésig Magyarország része volt, azon belül Bereg megyéhez tartozott. A csehszlovák időben (1920-1938/1939, 1944-1945) a falu neve Velká Dobron volt (BoTLIK J.-DuPKA GY. 1993). A szovjet közigazgatás (1945-1991) az Ungvári járásba sorolta, az 1960-as években egy ideig a Perecsenyi járás részét képezte (MóRICZ K. 1993). Ma használt neve a Nagydobrony, ukrán nyelven Велика Добронь. Kárpátalja negyedik legnépesebb, több mint 5000 főt számláló magyar közösségét foglalja magába (Molnár J.-Molnár D. I. 2005). Az Ukrajnában 2020 júliusában jóváhagyott közigazgatási reform alapján az Ungvári járáshoz tartozik, azon belül a Nagydobronyi kistérség (hromada) része (Molnár D. I.-TóTh-Orosz E. 2020).

A vizsgálatunk másik szegmensét képező Nagydobronyi Vadvédelmi Rezervátum (ukránul: Загальнозоологічний заказник загальнодержавного значення „Великодоброньський”) Kárpátalja harmadik legnagyobb országos jelentőségű védett területe 1736 ha $(17,4$ km²) kiterjedésú. A rezervátumot az Ukrán Szovjet Szocialista Köztársaság Miniszteri Tanácsának 1974. évi határozata alapján létesítették. Eredeti rendeltetése az itt fészkelő madarak és vadak élőhelyeinek védelme. Ukrajna Ökológiai és Természeti Erőforrások Minisztériumának 2012-es rendelete megerősíti a vadvédelmi (zoológiai) rezervátum státuszát (KMÁAÖTESZ 2020). 2009-ben a területén kijelölték a Tiszamelléki (Pritiszjánszkij) Tájvédelmi Park (ukránul: Притисянський регіональний ландшафтний парк) latorcai szakaszát is (KISH, R. et al. 2009). A NVR jogilag az Ungvári Állami Erdőgazdasághoz, azon belül a Nagydobronyi Erdészethez tartozik. Négy részlegből áll (1.ábra): Kozup-

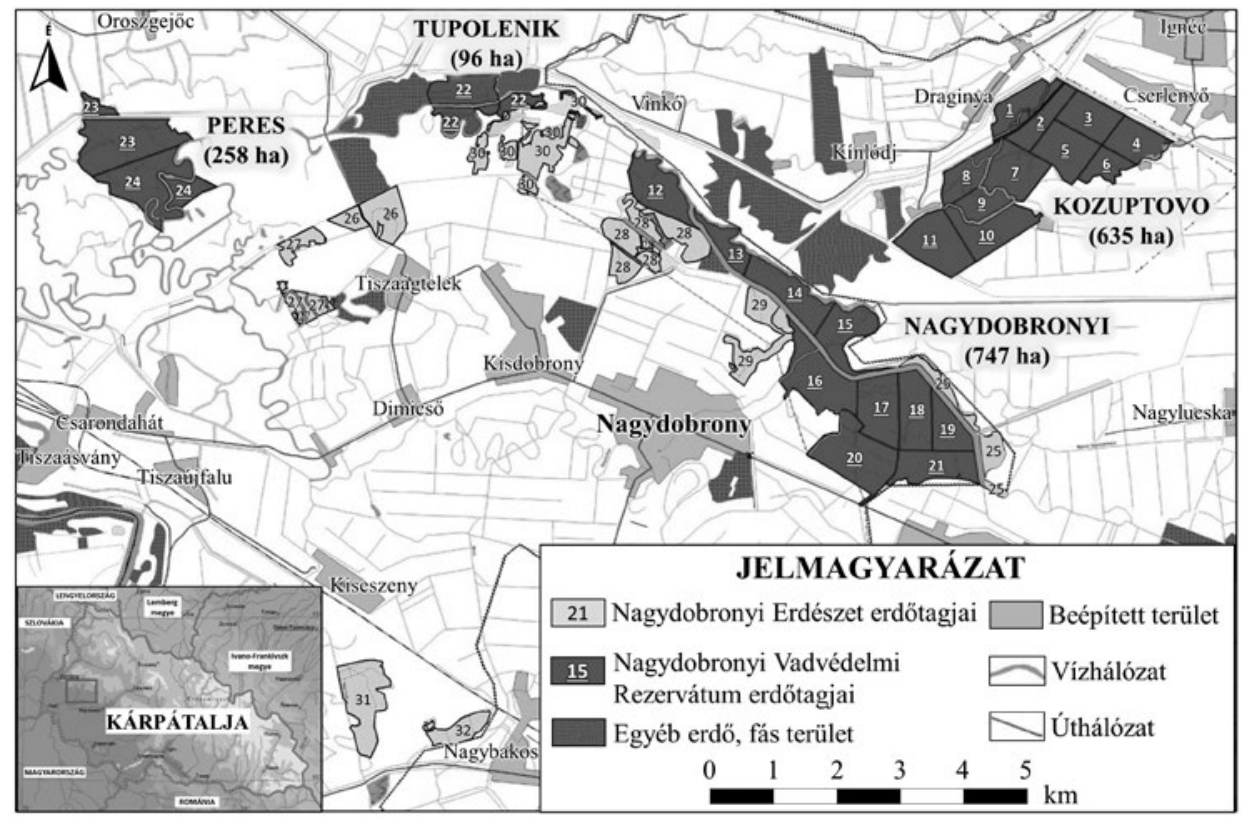

1. ábra A Nagydobronyi Vadvédelmi Rezervátum (NVR) részlegei és azok erdőtagjai (az Ungvári Állami Erdőgazdaság (2019) adatai alapján)

Figure 1 Parts and forest quarters of the Wildlife Reserve of Velyka Dobron (based on data from Uzhhorod State Forestry (2019)) 
tovo (635 ha), Nagydobronyi (747 ha), Tupolenik (96 ha) és Peres (258 ha). Az NVR részlegeiben összesen 24 erdőtagot különítenek el: a Kozuptovo részleg az 1-11., a Nagydobronyi a 12-21., a Tupolenik a 22., a Peres pedig a 23. és 24. számú erdőtagokból áll (1. ábra).

\section{A földrajzi nevek (határ-és dülönevek) egységesitett névtárának elkészítése}

Földrajzi neveknek az olyan tulajdonneveket tekintjük, amelyeket a földfelszín természetes (hegy, völgy, forrás, vízfolyás, tenger, táj stb.), illetve mesterséges (dűlő, csatorna, út, település, megye stb.) részleteinek azonosítására használnak (FARAGó I. 2016). A földrajzi nevek legnépesebb csoportját a határnevek vagy más néven határrésznevek alkotják. Határnéven a település kataszteri területén belül, nem a belterülethez tartozó földrajzi helyrészletet jelölő nevet értjük. A határneveket egy helység lakói adják településük külterületi részeinek azonosítására, ezért e nevek legtöbbször csak egy-egy település közigazgatási (kataszteri) határán belül helyezkedhetnek el (FARAGÓ I. 2016). Dúlő́n pedig az olyan mesterségesen kialakított, általában négyzetes alakú, mezsgyével határolt, általában mező- vagy erdőgazdasági múvelés alatt álló földdarabot értjük, amely a település külterületében, de kataszteri határán belül alakítottak ki a folyószabályozásokat követően és azt helyrajzi számmal láttak el (BíRó A. 1997). Ilyenformán a dúlő a határ, határrész szúkebb értelemben vett formája (LŐRINCZE L. 1947). A határ- és dűlőnevek tanúskodnak a határ régi természeti viszonyairól (pl. vízrajzáról, növényborítottságáról), az egykori művelési formákról, a termesztett növényekről, földhasználati módokról, a birtokbavétel módjáról, a birtoklási formákról és azok változásáról és a környező egykori településekről, azok neveiről.

A földrajzi névanyag (határ- és dűlőnév) összeállításához az alábbi online elérhető (http:// arcanum.hu/hu/) és (http://mapire.eu/hu/) nyilvános térkép-adatbázisokat használtuk fel:

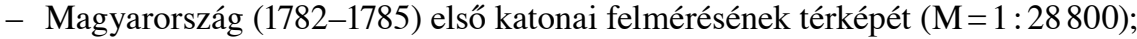

- Magyarország (1819-1869) második katonai felmérésének térképét ( $\mathrm{M}=1: 28800)$;

- Magyarország (1869-1887) harmadik katonai felmérésének térképét $(M=1: 25000$ és $\mathrm{M}=1: 75000)$;

- Magyarország (1865) kataszteri térképét.

Az 1865-ös Kataszteri térképen szereplő neveket kiegészítettük a katonai felmérések térképein szereplő földrajzi nevekkel és összevetettük a levéltári dokumentumokkal. A dúlōnevekhez hozzárendeltük a Kárpátaljai Területi Állami Levéltár beregszászi fiókjában megtalálható iratanyag (125. fond, 6. opisz. 344. iratcsomó) alapján a helyrajzi számokat. A nevek írásában az említett térképeken szereplő írásmódot követtük. A község határában lévő, a kataszteri térképen névvel nem jelölt, de jól elkülöníthető területekhez is hozzáírtuk a helyrajzi számokat, ezt táblázatba rendeztük. A kapott névanyagot összevetettük SEBESTYÉN Zs. (2008a) névanyagával, illetve Pesty Frigyes MizSER L. (1995) által közreadott Bereg megyei helységnévtárával (1864-1865). Nagydobrony község 1985-ös kataszteri határain belül esô és a NVR-hoz tartozó erdő földrajzi neveit digitalizált térképen ábrázoltuk.

\section{Az adatok térinformatikai feldolgozása és térképi ábrázolása}

A történeti tájak és azok változásának vizsgálatában, tipizálásában az írott források mellett komoly szerepe lett a geoinformatikai (GIS) módszerek alkalmazásának. A különböző források adatbázisainak, történeti térképeinek digitalizálása és térinformatikai feldolgozása jelentősen kitágította a térbeli elemzések és ábrázolások lehetôségét és egyúttal a távérzékelési adatok (pl. légi- és ûrfelvételek) forrásként való bevonását is (MóGA J. et al. 2014; CsOrBA P. et al. 2018). 
Nagydobrony és a NVR területe földrajzi részleteinek digitalizálását, majd a térképek elkészítését az ArcGis 10.1 térinformatikai szoftver segítségével végeztük el. Az online adatbázisból letöltött térképszelvényeket georeferáltuk, vetületbe illesztettük. A történelmi tájrészletek térképezését a vonalas objektumok (vízfolyás, határ, úthálózat, töltés) digitalizálásával kezdtük. Ezt követte a területtel rendelkező objektumok (erdők, dúlők, állóvizek, időszakosan vízzel borított területek) digitális ábrázolása. A dűlők és a különböző földhasználat alatt álló területek határait az 1865. évi kataszteri térkép és a levéltári helyrajzi számok alapján állapítottuk meg. A térképen a határrészeket és dűlőket számokkal jelöltük, ezek nevei a jelmagyarázatban szerepelnek. Az elkészült GIS attribútum-táblázatok és térképi shape-állományok a területen folyó további kutatások alapjai lehetnek.

\section{Eredmények}

Az I. katonai felmérés (1782-1785) térképének választott szelvényén jellemzően kevés földrajzi név szerepel Nagydobrony környékén. A két szomszédos település Kis Dobrony és Comonia (a mai Csongor) települések mellett Nagydobrony Nagy Dobra néven található meg. A település egy utcából áll, amelyen keresztülfolyik egy patak, a falu központjában egy kőtemplom van. A térképen szembetűnő a hatalmas összefüggő erdőtömb, amely északkeletről és délnyugatról körbezárja és határolja a települést. A folyónevek közül a Latorcza és Kerepez vízfolyásnevek olvashatók.

A II. katonai felmérés (1819-1869) térképén már szerepel a Nagydobrony falunév. Az előző térképhez képest sokkal részletgazdagabb és pontosabb a terület ábrázolása, több földrajzi név található. A térképet valószínúleg két rajzoló készítette, ez a lapok összeillesztésén és a térképrészletek színezésén is tapasztalható. Az összeillesztésnél eltérnek és felcserélődnek a folyónevek: a Grosse Latorcza a Kis Latorczával, a Kleine Latorcza a Nagy Latorczával folytatódik. A két rajzoló írásmódja is elkülöníthető. A folyók és patakok megnevezése mellett jól olvasható a Fluss (folyó) vagy a Bach (patak) szó. A jelkulcsot használva azt látjuk, hogy az elsőhöz képest a falu területe növekedett. A falu a Csólnakút $\mathrm{B}$ névvel jelölt patak két oldalán terül el, a központjában egy kőtemplom áll. A patakon három híd vezet át - bakhíd vagy faborítású híd; nem látható pontosan. Jól kivehető a vízszabályozást megelőző, kiterjedt vízrendszer és a folyóártér. A szabadon kanyargó Latorca mellékágrendszere részletesen van ábrázolva. A kivágaton a következő vízfolyások és állóvizek nevét találjuk: Nagy Latorcza, Csólnak-út (Csonok-út Bach is), Matzontza, Nagy Györtyös, Kis Györtyös, Nagy-Szabad-patak, Kis-Latorcza, Mosonca, Marton patak, Láb patak, Patakcsa Bach, Poroscsanyik, Borotsányék Györgyös, Fekete Tó, Horgas Tó. Ezek közül - a Latorca folyónév mellett - ma csak a Masonca név ismert a falubeliek körében. A falutól északkeletre elterülő, a NVR nagydobronyi részlegének legnagyobb részét alkotó akkori erdőtömb Kis Erdő nevén szerepel.

A III. katonai felmérés térképe (1869-1887) már részben a folyószabályozás utáni állapotokat rögzíti. A térkép fekete-fehér lenyomatos. Az erdő területe tovább csökkent. A falut keresztülszelő patak neve Hatracz-ra változott és összeköttetésben van a Latorcza Györgyos, Macsoncsa és Kerepecz patakokkal. A Kis erdő elnevezés az északkeleti egybefüggő erdőtömb Csomonyához (mai Csongorhoz) közelebb eső, kisebb területét jelöli. A nagyobb rész Felső erdőként szerepel. A vízfolyások nevein kívül számos dűlőnév vagy majorság neve is fel van tüntetve, ami a földhasználatra utal. A szántók nem különülnek el a rétektól és mezőktől, amelyek az összefüggő erdőtömböt bontják meg. A gyümölcsösök sem különülnek el. Pesty (1864-1865) leírásában a Vörös Gorondon gyümölcsös van. A térképen a terület neve Vörös Gorom, vonalkázással elkülönül az erdőtől és a vele érintkező mezőtől. 
A térképszelvényen olvasható földrajzi nevek: Felső erdő, Kis erdő, Katoszög, Mocsonka, Zucska, Kis gara, Szomogya, Vörös gorom, Daranyo, Tamas eger, Kerepeczi erdő, Also erdő. A folyó- és pataknevek közül a következőket találjuk a térképen: Str. Latorca, Hatracz patak, Maconca patak, N. eger, Száraz Latorca, Latorcai csatorna, Kerepecz patak, Szernye patak, Bara patak. Az eredeti nagy térképes ábrák megvannak és felhasználhatók a jövőbeni kutatások során. Nagydobrony és a NVR jelenkori elhelyezkedését és kiterjedését ábrázoltuk az egykori katonai felmérések térképein, ezek a nagy térképes ábrák rendelkezésre állnak és felhasználhatók a jövő́beni kutatások során.

A kataszteri térképen (1865) rögzítettek is már számos folyó és patak medrének szabályozásáról tanúskodnak. A községet és határrészeit átszövő folyó- és csatornahálózat nevei közül a Latorcza folyó, Latorcza ág, Hatrácz (az előző térképen Hatracz) patak, Mocsonka, Macsoncza patak, Daranyó csatorna, Magasparti csatorna, Kerepecz patak, Hatamsa, Kis patak, Zseje patak feliratokat találjuk meg, továbbá egy névvel nem, csak számmal ellátott csatornát: 3424 csatorna.

A digitalizált térképen (2. ábra) számmal jelölve, északról délre haladva feltüntettük a Nagydobrony 1865-ös kataszteri határain belül eső és a NVR területén található valamennyi határrészt és dúlőt. Továbbá kiemeltük Nagydobrony jelenkori lakott és beépített területét, a környező erdők jelenlegi kiterjedését, valamint a nagyfokú mederszabályozáson átesett vízhálózatot.

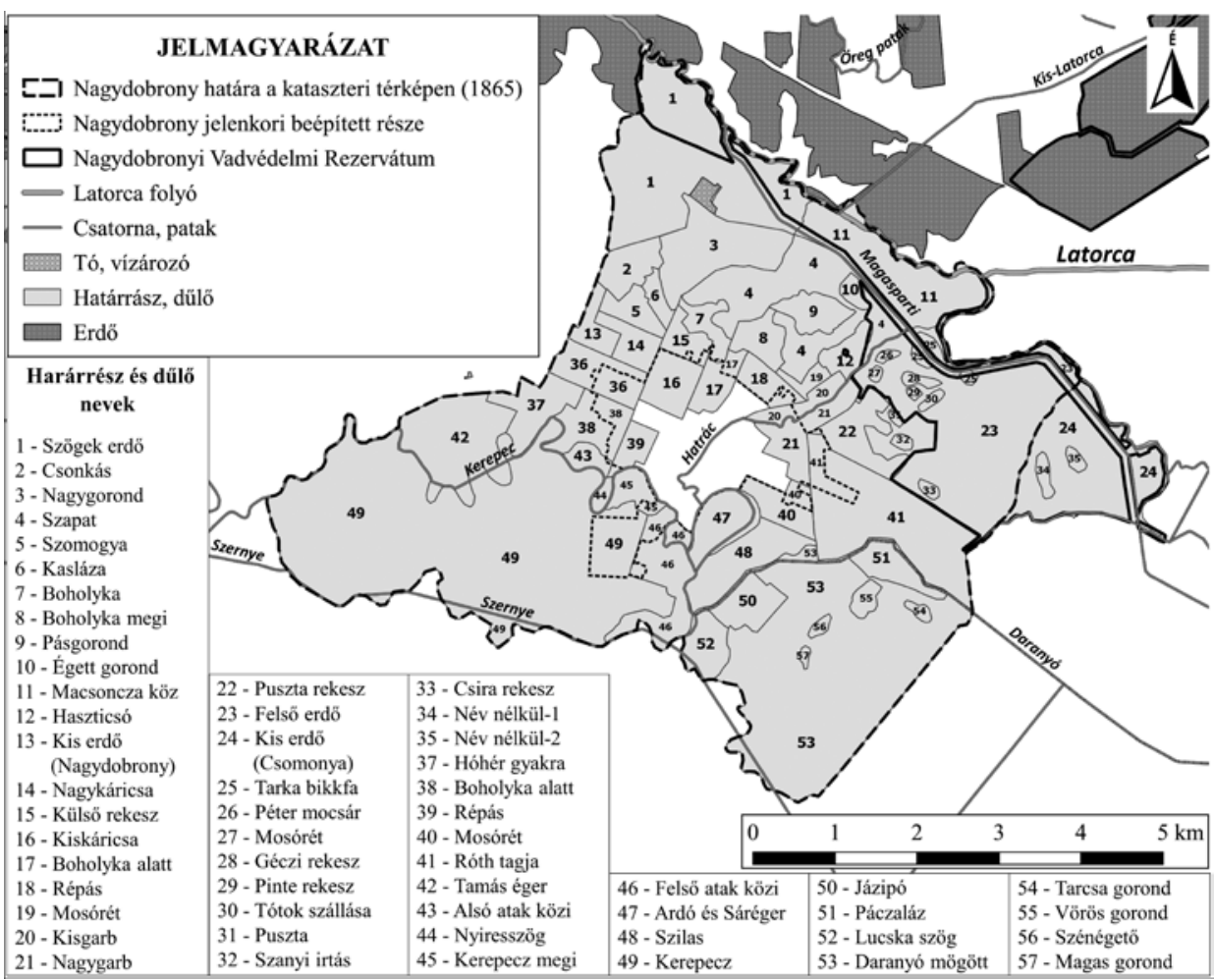

2. ábra Nagydobrony és a NVR földrajzi nevei (határ- és dúlőnevei)

(Magyarország kataszteri térképe (1865) alapján)

Figure 2 Geographical names of Velyka Dobron and the WRVD

(based on the cadastral map of Hungary (1865)) 
Célkitűzésünknek megfelelően elkészítettük Nagydobrony község és a NVR területének egységesített földrajzinév-tárát. A dűlőnevekhez hozzárendeltük a beregszászi levéltárból származó iratanyag (125. fond, 6. opisz. 344. iratcsomó) alapján a helyrajzi számokat. Ezt kiegészítettük a NVR területén lévő, a kataszteri térképen szereplő, névvel nem jelölt, de jól elkülöníthetô területekkel, határrészekkel, amelyekhez szintén hozzárendeltük a helyrajzi számokat, s ezt táblázatba rendeztük (1. táblázat). Ebben összesen 57 határ-és dúlőnév szerepel. A 2. ábrán 24-es számmal jelölt Kis erdő és két, név nélküli kisebb dűlő a NVR területén van, de az 1865-ös kataszteri térkép szerint már Csomonyához (Csongorhoz) tartozik.

1. táblázat - Table 1

Nagydobrony és a NVR földrajzi neveinek (határ- és dűlőneveinek) adattára

Database of geographical names

(names of pieces of land) of Velyka Dobron and the WRVD

\begin{tabular}{|c|c|c|c|c|c|c|c|}
\hline ह & Határ- és dúlónév & 粷离离 & $\begin{array}{r}\text { Kata } \\
\text { sze }\end{array}$ & $\begin{array}{l}\text { zteri } \\
\text { m }\end{array}$ & 苂 & $\begin{array}{c}\text { Napjainkban jelölt } \\
\text { területtípus }\end{array}$ & $\begin{array}{c}\text { Pesty Frigyes } \\
\text { helységnévtárában } \\
\text { (1864-1865) } \\
\text { szereplő dúlónevek, } \\
\text { azok által } \\
\text { jelölt területtípus }\end{array}$ \\
\hline 1 & Alsó atak közi & 43 & 1564 & 1585 & 0,14 & szántóföld & szántóföld \\
\hline 2 & Általút mente & 40 & 3701 & 3745 & 0,38 & szántóföld, beépített terület & - \\
\hline 3 & Ardó és Sáréger & 47 & 3746 & 3820 & 0,51 & szántó, beépített terület & sástermő, lapos hely \\
\hline 4 & Boholyka & 7 & 2551 & 2556 & 0,24 & szántóföld, legelő & rét \\
\hline 5 & Boholyka alatt & 17 & 1319 & 1410 & 0,30 & beépített terület & rét \\
\hline 6 & Boholyka megi & 8 & 2557 & 2695 & 0,30 & szántóföld, legelő & rét \\
\hline 7 & Csira rekesz & 33 & 3144 & 3146 & 0,04 & erdő & gyümölcsös \\
\hline 8 & Csonkás & 2 & 2065 & 2170 & 0,37 & szántóföld & gyümölcsös \\
\hline 9 & Daranyó mögött & 53 & 3596 & 3700 & 5,10 & szántó & községi erdőrész \\
\hline 10 & Dombos & 27 & 3123 & 3128 & 0,02 & felújuló erdő, írtásrét & gyümölcsös \\
\hline 11 & Égett gorond & 10 & 2938 & 2970 & 0,10 & írtásrét & gyümölcsös \\
\hline 12 & Felső atak közi & 46 & 4140 & 4408 & 0,86 & szántó, beépített terület & szántóföld \\
\hline 13 & Felső erdő & 23 & 3088 & 3149 & 3,66 & erdő & községi erdőrész \\
\hline 14 & Forráshát & 39 & 1442 & 1461 & 0,21 & beépített terület & szántóföld \\
\hline 15 & Géczi rekesz & 28 & 3107 & 3117 & 0,06 & beépített terület, felújuló erdő & - \\
\hline 16 & Haszticsó & 12 & 2846 & 2937 & 0,24 & szántóföld & gyümölcsös \\
\hline 17 & Hóhér gyakra & 36 & 1832 & 1923 & 0,53 & szántóföld, beépített terület & - \\
\hline 18 & Hosszú földek sorja & 38 & 1586 & 1693 & 0,52 & szántóföld, beépített terület & szántóföld \\
\hline 19 & Jázipó & 50 & 3980 & 4076 & 0,40 & szántó & - \\
\hline 20 & Kasláza & 6 & 2038 & 2064 & 0,13 & szántóföld & - \\
\hline 21 & Kerepecz & 49 & 4409 & 4465 & 7,99 & szántó, beépített terület & uradalmi erdőrész \\
\hline 22 & Kerepecz megi & 45 & 1462 & 1543 & 0,25 & szántó, beépített terület & uradalmi erdőrész \\
\hline 23 & Kis erdő (Csomonya) & 24 & 1483 & 1497 & 1,97 & erdő & községi erdőrész \\
\hline 24 & Kis erdő (Nagydobrony) & 13 & 1972 & 2006 & 0,24 & szántóföld & szántóföld \\
\hline 25 & Kisgarb & 20 & 2764 & 2791 & 0,24 & szántóföld, beépített terület & szántóföld \\
\hline 26 & Kiskáricsa & 16 & 1411 & 1441 & 0,41 & beépített terület & rét \\
\hline 27 & Külső rekesz & 15 & 2510 & 2550 & 0,23 & szántóföld & irtásföld, gyümölcsös \\
\hline 28 & Lucska szög & 52 & 4077 & 4139 & 0,37 & szántó & gyümölcsös \\
\hline 29 & Macsoncza köz & 11 & 3071 & 3087 & 1,47 & erdő & uradalmi erdőrész \\
\hline 30 & Magas gorond & 57 & 3604 & 3608 & 0,02 & szántó & - \\
\hline 31 & Meritőhát & 37 & 1694 & 1831 & 0,52 & szántóföld, beépített terület & - \\
\hline 32 & Mosórét & 19 & 2696 & 2729 & 0,11 & szántóföld & rét \\
\hline 33 & Nagygarb & 21 & 2792 & 2845 & 0,50 & szántóföld, beépített terület & szántóföld \\
\hline 34 & Nagygorond & 3 & 2186 & 2509 & 1,15 & szántóföld & gyümölcsös \\
\hline 35 & Nagykáricsa & 14 & 1924 & 1971 & 0,29 & szántóföld & rét \\
\hline 36 & Név nélkül-1 (Kis erdő) & 34 & 1484 & 1489 & 0,08 & erdő & - \\
\hline 37 & Név nélkül-2 (Kis erdő) & 35 & 1490 & 1497 & 0,05 & erdő & - \\
\hline 38 & Nyiresszög & 44 & 1544 & 1563 & 0,07 & szántóföld & rét, szántőföld \\
\hline 39 & Pácza láz & 51 & 3480 & 3574 & 0,39 & szántó & - \\
\hline 40 & Pás gorond & 9 & 2971 & 3065 & 0,32 & szántóföld & gyümölcsös \\
\hline 41 & Péter mocsár & 26 & 3118 & 3122 & 0,03 & felújuló erdő, írtásrét & - \\
\hline
\end{tabular}




\begin{tabular}{|c|c|c|c|c|c|c|c|}
\hline \multirow{2}{*}{ 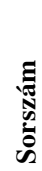 } & \multirow{2}{*}{ Határ- és dúlónév } & \multirow{2}{*}{ 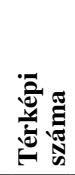 } & \multicolumn{2}{|c|}{$\begin{array}{l}\text { Kataszzteri } \\
\text { szám }\end{array}$} & \multirow{2}{*}{ 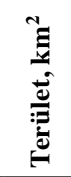 } & \multirow{2}{*}{$\begin{array}{l}\text { Napjainkban jelölt } \\
\text { területtípus }\end{array}$} & \multirow{2}{*}{$\begin{array}{c}\text { Pesty Frigyes } \\
\text { helységnévtárában } \\
\text { (1864-1865) } \\
\text { szereplő dúloónevek, } \\
\text { azok által } \\
\text { jelölt területtípus }\end{array}$} \\
\hline & & & -tól & $-i g$ & & & \\
\hline 42 & Pinte rekesz & 29 & 3129 & 3130 & 0,02 & felújuló erdő, írtásrét & - \\
\hline 43 & Puszta & 31 & 3136 & 3137 & 0,02 & szántóföld & - \\
\hline 44 & Puszta rekesz & 22 & 3150 & 3245 & 0,51 & szántóföld & szántóföld \\
\hline 45 & Répás & 18 & 2730 & 2763 & 0,27 & szántóföld, lakott terület & - \\
\hline 46 & Róth tagja & 41 & 3246 & 3479 & 1,95 & szántóföld, beépített terület & - \\
\hline 47 & Szanyi irtás & 32 & 3138 & 3143 & 0,04 & szántóföld & - \\
\hline 48 & Szapat & 4 & 3066 & 3070 & 1,72 & erdő, legelő & vizes, lápos hely \\
\hline 49 & Szénégető & 56 & 3609 & 3623 & 0,04 & szántó & kiszáradt patakmeder \\
\hline 50 & Szilas & 48 & 3821 & 3979 & 0,69 & szántó & irtásföld, kaszáló \\
\hline 51 & Szomogya (Szomoga) & 5 & 2007 & 2037 & 0,26 & szántóföld & szántóföld \\
\hline 52 & Szögek erdó & 1 & 2171 & 2185 & 3,18 & erdő & községi erdőrész \\
\hline 53 & Tamás éger & 42 & 4466 & 4476 & 1,24 & szántóföld & mocsaras erdő \\
\hline 54 & Tarcsa gorond & 54 & 3596 & 3603 & 0,05 & szántó & gyümölcsös \\
\hline 55 & Tarka bikkfa & 25 & 5095 & 3106 & 0,12 & erdő, felújuló erdő, írtásrét & gyümölcsös \\
\hline 56 & Tótok szállása & 30 & 3131 & 3135 & 0,04 & felújuló erdő, írtásrét & \\
\hline 57 & Vörös gorond & 55 & 3575 & 3595 & 0,11 & szántó & gyümölcsös \\
\hline
\end{tabular}

\section{Diszkusszió}

A pontos adattár és térkép elkészítéséhez az általunk összeállított névanyagot összevetettük SEBESTYÉN Zs. (2008a) nagydobronyi helyneveivel. Helynévfelsorolása szintén levéltári anyagok alapján készült: 1863 (125.1.661.K), 1865 (125.1.654), 1908 (125.1.662.K), 1908 (125.1.655), 1908 (125.1.656). A fond száma azonos, de az opisz és az iratcsomó nem egyezik az általunk vizsgálttal. Ezek között van (K-val jelölt) kataszteri térkép, birtokrészleti jegyzőkönyv és határjárásokból származó adat. A helynevek a következőképpen oszlanak meg: 1865-ből 66, 1908-ból először 57, másodszor 41 és végül 14 nevet közöl. Az 1865ből származó nevek közül több nem szerepel a kataszteri térképen: Alsó erdő, Aták hát, Barcsú, Bekeny ádal, Belső szőg, Csorgo hát, Dárnin patak, Estván tava, Fejér rét, Irtás, Malom gorond, Pázá szőg, Remecs hát, Sárdombjo, Szilos mocsár, Tyukszoros nyáros, valamint több esetben a közölt írásmód nem egyezik a térképen megtalálható nevekkel. Ez vélhetően azzal is magyarázható, hogy a birtokrészleti jegyzőkönyvben szereplő megnevezést úgy írták, ahogy hallották: pl. Nyárossziget azonos a Nyiresszöggel. Az 1908-ból (125.1.662.K) származó helységnevekkel, földrajzi nevekkel találtuk a legnagyobb átfedést.

Pesty Frigyes Bereg megye helységnévtárában Nagydobrony községre vonatkozóan találjuk a legtöbb topográfiai földrajzi és dúlőnevet, összesen 113-at. Ebből 11 pataknevet jelöl: Bokolyka pataka, Csonok út pataka, Daranyó patak, Dublutska pataka, Hatracz pataka, Kurta Matsoncza patak, Matsoncza patak, Merdencze pataka, Szamáró, Szetti patak, Zseje patak. Összevetve a kataszteri térképet a Pesty Frigyesnél szereplő dúlőnevekkel kiderül, hogy 102-ből 40 szerepel a kataszteri térképen (1. táblázat). Érdekes, hogy néhány dưlőnév a kataszterin nem szereplők közül a mai napig is ismeretes a falubeliek előtt (pl. Aranyos domb, Cserge domb).

Nagydobrony kataszteri földjeinek teljes területe az 1865-ös térkép alapján 40,71 km² volt. A beépített, lakott részek egyre növekedtek: míg az 1780 -as években csupán $0,09 \mathrm{~km}^{2}$ volt, az 1850-esekben 0,28 km², az 1880-asokban 0,47 km², az 1940-esekben (Magyarország katonai felmérése, 1941) $1,36 \mathrm{~km}^{2}$ lett, jelenleg pedig $4,35 \mathrm{~km}^{2}$. Ennek következtében napjainkra 16 dúlő, teljesen elvesztette egykori jellegét, a település belterületének részévé vált. Számos dúlő a II. és a III. katonai felmérés térképén még összefüggő erdőt (pl. Kerepecz) 
vagy mocsaras, ingoványos fás területet (pl. Tamás éger) jelöl (1. táblázat). A folyószabályozás és az extenzív mezőgazdaság következtében ezek a kiterjedt erdők gyors fogyásnak indultak. A fennmaradt dúlőket ma már főként szántók, kisebb részben beépített, lakott településrészek foglalják el.

A Nagydobrony határában valaha hatalmas területeket beborító erdő maradványa ma is megtalálható. Az 1800-as években, a mai Kárpátalját lefedő Ung, Bereg, Ugocsa és Máramaros megyék a történelmi Magyarország jelentős erdős tájai voltak. A Nagydobronyt magába foglaló Ung vármegyét a hetedik legerdősebb vármegyeként tartották számon (FÖlDVÁRY L. 1941). Az I. világháborút lezáró trianoni békeszerződés következtében Magyarország elvesztette erdeinek legértékesebb 84\%-át; az erdősültség 26\%-ról 12\%-ra csökkent és Európa fában egyik legszegényebb országává vált (STANDOVÁR T. 2012). Az 1939 végén visszacsatolt felvidéki területsáv és Kárpátalja erdeinek területére összeállított ideiglenes erdőtörzskönyvek összesített adatait összehasonlítva a Trianont közvetlenül megelőző időkből származó adatokból kiderül, hogy a visszacsatolt felvidéki területsávon mintegy 20 ezer ha $\left(200 \mathrm{~km}^{2}\right)$, Kárpátalján pedig 80 ezer ha $\left(800 \mathrm{~km}^{2}\right)$ erdőt irtottak ki (FöLDVÁRY L. 1941). Magyarország ennyivel kevesebb erdőt kapott vissza, mint amennyit Trianonnal elveszített. Ebben az időszakban az erdők jellemző fajösszetételét FöLDVÁRY L. (1940) három jellegzetes fajcsoportba sorolja. A síkvidéktől a dombvidéken át az előhegységekig tölgyesek borítják öt fajváltozattal. A középhegységekben és az előhegységek húvösebb, északra néző oldalain, a bükkös állományok következnek, följebb, a közép- és magashegységekben különféle fajösszetételű fenyvesek találhatók.

Nagydobrony az első bécsi döntést követően tehát újra visszakerült Magyarországhoz, Ung megyéhez. Az 1938. évi statisztikai adatok szerint a községnek ebben az időben 1253

kataszteri (katasztrális) hold (721 ha, azaz 7,21 km²) erdőterülete volt (Magyar statisztikai közlemények 1939). Az ezt követő szovjet érában az erdők területe tovább csökkent. Az 1865-ös kataszteri térképen szereplő településhatárokat alapul véve összehasonlítottuk az I., II. és III. katonai felmérés térképein és az 1941-es magyarországi katonai térképen berajzolt, valamint a jelenkori múholdfelvételen látható, a kataszteri határon belül húzódó erdők összterületét. Az erdők kiterjedése jelentősen csökkent: az 1780-as években még közel $30 \mathrm{~km}^{2}$-nyi erdő volt a valamikori kataszteri határokon belül, az 1850-esekben 21, az 1880-asokban 19, az 1940-esekben pedig már csak $10 \mathrm{~km}^{2}$. A Google Earth 2019. évi múholdfelvételei szerint ez az erdőterület csupán $8,17 \mathrm{~km}^{2}$. Az Ungvári Állami Erdőgazdaság teljes erdőterülete 2019-ben 17201 ha $\left(172 \mathrm{~km}^{2}\right)$ volt, ebből a Nagydobronyi Erdészethez 2258 ha $\left(22,6 \mathrm{~km}^{2}\right)$ tartozik, amelynek $77 \%$-a $\left(17,4 \mathrm{~km}^{2}\right)$ a Nagydobronyi Vadvédelmi Rezervátum része (Ungvári Állami Erdőgazdaság 2019).

\section{Összefoglalás}

A Kárpátalja negyedik legnépesebb magyar közösségét magába foglaló Nagydobrony község mellett elterülő Nagydobronyi Vadvédelmi Rezervátum a megye harmadik legnagyobb, országos jelentőségú védett rezervátuma. A 18. és 19. századi Magyarország területéről készült I., II. és III. katonai felmérés, az 1865. évi kataszteri térkép, valamint a Kárpátaljai Területi Állami Levéltár beregszászi fiókjában megtalálható iratanyag (125. fond, 6. opisz. 344. iratcsomó), továbbá irodalmi anyagok alapján elvégeztük a település és a védett terület történeti földrajzi helyneveinek (határ- és dúlőneveinek) térinformatikai feldolgozását és térképi ábrázolását. A területrôl egy 57 elemből álló névtárat állítottunk össze. A település egykori kataszteri határain belül és a Nagydobronyi Vadvédelmi Rezervátum területén húzódó határrészekről és dúlőkkrőlösszefoglaló térképet készítettünk. Elemeztük 
az erdőterület és a földhasználat változásait, aminek következtében napjainkra 16 dúlő, teljesen elvesztette egykori jellegét, a település belterületének részévé vált. Reményeink szerint az elkészült adattár és térképek segítségével megvalósítható a már itt folyó vagy elvégzett kutatások helyének pontosítása, illetve egyértelmúsítése.

\section{KoHUT ERZSÉBET \\ II. Rákóczi Ferenc Kárpátaljai Magyar Főiskola, Biológia és Kémia Tanszék, Beregszász kohut.erzsebet@kmf.org.ua}

\section{BENEDEK ANETT}

II. Rákóczi Ferenc Kárpátaljai Magyar Főiskola, Biológia és Kémia Tanszék, Beregszász benedekanett1@gmail.com

\section{HADNAGY ISTVÁN}

II. Rákóczi Ferenc Kárpátaljai Magyar Főiskola, Biológia és Kémia Tanszék, Beregszász hadnagy.istvan@kmf.org.ua

\section{IRODALOM}

BEREGSZÁSZI A. 1998: Magyar helységnevek Kárpátalján (1988-1995). - In: KACSUR G. (szerk.): Útközben. Kárpátaljai Magyar Kulturális Szövetség, Ungvár. pp. 85-91.

BíRó A. 1993: Kárpátalja településeinek földrajzi nevei. - In: Lizanec, P.-HoRváth, K. (szerk.): Az Ungvári Hungarológiai Intézet tudományos gyűjiteménye, Intermix Kiadó, Ungvár-Budapest. pp. 134-143.

Bíró F. 1997: Dúlők és dưlőnnevek a Körösök vidékén. - Magyar Nyelvtudományi Intézetének Kiadványai 209. pp. 448-54.

BotLiK J.-DuPKa Gy. 1993: Magyarlakta települések ezredéve Kárpátalján. - Intermix Kiadó, UngvárBudapest. 209 p.

CsORBA P.-NAGY I.-CsÜLLÖG G. 2018: A földrajzi tájak tipizálása európai kitekintéssel. - Földrajzi Közlemények 142. pp. 272-290. https://doi.org/10.32643/fk.142.4.2

DELI, T.-SÜMEGI,P. 1999: Biogeographical characterisation of Szatmár-Bereg plain based on the mollusc fauna. - In: The Upper Tisa valley: preparatory proposal for Ramsar site designation and an ecological background Hungarian, Romanian, Slovakian and Ukrainian co-operation 4. pp. 471-477.

DEMETER L. 2013: A Szernye-csatorna menti Seleszta kiserdő cönológiai vizsgálata. - Acta Academiae Beregsasiensis 12.pp. 263-271. http://real.mtak.hu/34498/1/Acta_2013_1_Sajat_u.pdf

DEMETER, L. 2016: Biodiversity and Ecosystem Services of Hardwood Floodplain Forests: past present and future from the perspective of local communities in West Ukraine. - In: RouÉ, M.-MoLnár, Zs. (eds): Knowing our Land and Resources: Indigenous and Local Knowledge of Biodiversity and Ecosystem Services in Europe and Central Asia. Knowledges of Nature, 9, UNESCO: Paris. pp. 6-19.

FARAGÓ I. 2005: A magyar földrajzinév-használat. - Könyvtári figyelő 51. pp. 791-817.

FARAGó I. 2016: Ber, Bere, Berény [,] avagy helynévadás a Kárpát-térségben. - Fríg Kiadó, Budapest. 340 p.

FöLDVÁRY L. 1940: A kárpátaljai kincstári erdők fa faj megoszlása. - Magyar Statisztikai Szemle 3. pp. 5-193.

FÖLDVÁRY L. 1941: Erdőgazdaságunk a keleti és északerdélyi területrészek felszabadulása után. - In: MAGYAR P. (szerk.): Erdészeti Kísérletek 43. pp. 4-71.

GÁBRIEL A. 1991: Hagyományos tájnevek, földrajzi nevek. - Földrajzi Értesítő 40. pp. 161-164.

GÁBRIS Gy. 2019: Névföldrajzi kutatások - egy családnév földrajzi és történelmi háttere. - Földrajzi Közlemények 143. pp. 35-54. https://doi.org/10.32643/fk.143.1.4

JuHÁsz D. 1988: A magyar tájnévadás. - Akadémiai Kiadó, Budapest. 109 p.

Kish, R.-ANDRIK, E.-MirUTENKo, V. 2006: Natura 2000 biotopes in the Transcarpathian lowlands [Біотопи Natura 2000 на Закарпатській низовині]. - Мистецька лінія, Ужгород. 64 р.

Kish, R.-Prots, B.-Polyanovsky A.-Bashta, T.-Danylyk, I. 2009: Prytysianskyi Regional Landscape Park - preservation of the natural heritage of the plains of Transcarpathia [Регіональний ландшафтний парк «Притисянський» - збереження природної спадщини рівнинного Закарпаття]. - Мистецька Лінія, Ужгород. 20 p.

Kiss L. 1980: Földrajzi nevek etimológiai szótára, I-II. kötet. - Akadémiai Kiadó, Budapest. 727 p. 
KISS L. 1999: A Kárpát-medence régi helynevei. - In: KISS L. (szerk.): Történeti vizsgálatok a földrajzi nevek körében. Pázmány Péter Katolikus Egyetem, Bölcsészettudományi Kar, Piliscsaba. 355 p.

KMÁAÖTESZ 2020: Kárpátalja környezeti monitoring rendszere [Система моніторингу довкілля Закарпатської області]. - Kárpátaljai Megyei Állami Adminisztráció Ökológiai és Természeti Erőforrások Szakosztálya [Департамент екології та природних ресурсів Закарпатської облдержадміністрації]. http://ecozakarpat.net.ua

Kohut E. 2013: A Sirynga josikea Jaq. fil. ex Rchb. és a Leucojum aestivum L. kárpátaljai természetes állományainak felmérése és in vitro szaporítása. - Doktori (PhD-) értekezés. Corvinus Egyetem, Budapest.

Kohut E.-HöHn M.-JÁMborné Benczúr E. 2006: A Masonca mocsárrét botanikai vizsgálata. - Acta Beregsasiensis 5. pp.157-167.

Kohut E.-HöHn M.-FülöP M.-Kopor Z.-LjubKa T.-MolnáR F.-TAKÁcs G. 2017: Előzetes eredmények a tavaszi tőzike (Leucojum vernum L.) populációjának állapotáról a Peresben. - Limes 14. pp. 9-22. http://kmf.uz.ua/wp-content/uploads/2018/02/Limes2018.pdf

Kohut, E.-Kopor, Z.-NAGY, B.-Csoma, Zs.-HadnaGy, I. 2019: Evaluation of morphometric parameters in case of Leucojum vernum L. from the peres forest in Velyka Dobron Wildlife Reserve, Western Ukraine. - Acta Biologica Marisiensis, 2.pp. 26-35. https://doi.org/10.2478/abmj-2019-0008

Kohut, E.-Ördögh, M.-JÁmbor-Benczúr, M.-MÁthé, Á. 2007: Results with the establishment of in vitro culture of Leucojum aestivum L. - International Journal of Horticultural Science 13. pp. 67-71.

KolozSVÁRI, I.-DÉVAI, GY.-SzABó, L. J. 2015a: Occurrence pattern analysis of dragonflies (Odonata) on the River Tisza between Vilok and Huszt based on exuviae. - Applied Ecology and Environmental Research 13. pp. 1183-1196. https://doi.org/10.15666/aeer/1304_11831196

KolozsváRI, I.-SzABó, L. J.-DÉVAI Gy. 2015b: Dragonfly assemblages in the upper parts of the River Tisza: a comparison of larval and exuvial data in three channel types. - Acta Zoologica Academiae Scientiarum Hungaricae 61.pp. 189-204. https://doi.org/10.17109/AZH.61.2.189.2015

KovÁcs A. 2008: Magyar személynévkutatás Kárpátalján. - Névtani Értesítő 30. pp. 203-210.

LEHOCZKY T. 1881-1882/1996: Bereg vármegye monográfiája. - Hatodik Síp Alapítvány-Mandátum, BudapestBeregszász. 501 p.

LŐRINCZE L. 1947: Földrajzneveink élete. - Néptudományi Intézet, Budapest. 32 p.

MagurA, T.-KöDÖвöcz, V. 2005: Forests of the Bereg-Plain as Refuges Based on Their Carabid Fauna (Coleoptera: Carabidae). - Acta Phytopathologica et Entomologica Hungarica 40. pp. 367-382. https://doi.org/10.1556/aphyt.40.2005.3-4.18

Magura, T.-KöDöвöcz, V.-TóthméRÉsz, B.-MolnáR, T.-Elek, Z.-SzILÁgYi, G.-Hegyessy, G. 1997 : Carabid fauna of the Beregi-síkság and its biogeographical relations (Coleoptera Carabidae). - Folia Entomologica Hungarica 58. pp. 73-82.

Magyar statisztikai közlemények 1939: Az 1938. évi Felvidéki nép-, földbirtok- és állatösszeírás. Az 1938. november 2-i Bécsi döntés alapján visszacsatolt területen végrehajtott összeírás eredményei községek szerint. - Magyar Királyi Központi Statisztikai Hivatal, Budapest. 277 p.

Mizser L. 1995: Bereg megye Pesty Frigyes helységnévtárában (1864-1865). - Szabolcs-Szatmár-Bereg Megyei Levéltárának évkönyve 11.pp. 397-491.

MizsER L. 1996: A Latorca-vidék ősvízrajza és ártéri gazdálkodása. - In: FRISNYÁK, S. (szerk.): A Kárpátmedence történeti földrajza, MTA Szabolcs-Szatmár-Bereg Megyei Tudományos Testülete, Bessenyei György Tanárképző Főiskola Földrajz Tanszéke, Nyíregyháza, pp. 321-326.

MizsER L. 2004: Nagydobrony és Zápszony családnevei. - Magyar Nyelvjárások 42. pp. 209-216.

Molnár D. I.-Tóth-Orosz E. 2020: Decentralizáció Kárpátalján. - Hodinka Antal Nyelvészeti Kutatóközpont, II. Rákóczi Ferenc Kárpátaljai Magyar Főiskola.

URL: http://hodinkaintezet.uz.ua/decentralizacio-karpataljan/

MolnÁR D. I. 2014: A kárpátaljai magyar településnevek változása a XX. század folyamán. - In: BEREGSZÁSZI, A.-HiRES-LÁszló, K. (szerk.): Meszelt falakon túl, Születésnapi köszöntőkötet Kótyuk István tiszteletére. II. Rákóczi Ferenc Kárpátaljai Magyar Főiskola, Beregszász. pp. 131-150.

MolnÁR J.-MolnÁR D. I. 2005: Kárpátalja népessége és magyarsága a népszámlálási és népmozgalmi adatok tükrében. - II. RF KMF, PoliPrint, Beregszász-Ungvár. 115 p.

Móga J.-Szabó M.-Mari L.-Borsodi A.-Kéri A.-KnÁB M.-Kiss K.-Iván V. 2014: Természeti és antropogén hatásokra végbemenő tájváltozások vizsgálata a Bakonyban. - Földrajzi Közlemények 138. pp. 89-106. URL: https://www.foldrajzitarsasag.hu/downloads/foldrajzi_kozlemenyek_2014_138_evf_2_szam.pdf

MórICZ K. 1993: Nagydobrony. - Hatodik Síp Alapítvány, Budapest. 351 p.

NovÁk, P.-ZuKAL, D.-VEČEŘA, M.-PÍŠŤKOVÁ, K. 2017: Vegetation of oak-hornbeam, scree and ravine forests at lower altitudes in Transcarpathia, Western Ukraine. - Tuexenia 37. pp. 47-63. https://doi.org/10.14471/2017.37.021

Prots, B. 2010: Floodplain forests of the Transcarpathia (Ukraine): living close to human. - Journal Biological Systems 3. pp. 58-62. 
SEBESTYÉn Zs. 2003: Beregvidéki helységnevek. - Névtani Értesítő 25. pp. 58-63.

SEBESTYÉn Zs. 2008a: Kárpátalja településeinek történeti helynevei a kataszteri térképek és birtokrészleti jegyzőkönyvek alapján. - Bessenyei Könyvkiadó, Nyíregyháza. 236 p.

SEBESTYÉn Zs. 2008b: Növénynevek beregvidéki helységnevekben. - In: P. LaKatos I.-Pethỏ J. (szerk.): Elméletek és módszerek. Tanulmányok a nyelvtudomány köréből. A Nyíregyházi Fơiiskola Magyar Nyelvészeti Tanszékének kiadványai. Nyíregyháza. pp. 99-108.

SEBESTYÉn Zs. 2010: Bereg Megye helységneveinek etimológiai szótára. - Bessenyei Könyvkiadó, Nyíregyháza. $168 \mathrm{p}$.

SEBESTYÉN Zs. 2015: Szláv helynévképzők kárpátaljai helységnevekben. - In: Korszerú tudomány, korszerú közoktatás: tanulmányok a nyelv- és irodalomtudományok köréből. Nyíregyházi Fiőskola, Nyíregyháza, pp. 75-89.

SeBESTYÉn Zs. 2016a: Kárpátalja víznevei: a Fekete-Tisza völgye. - Acta Beregsasiensis 15. pp. 183-198. http://kmf.uz.ua/wp-content/uploads/2017/01/Acta2016_ff.pdf

SEBESTYÉn Zs. 2016b: Hegynevek és településnevek a Felső-Tisza vidékén. - Névtani Értesítő 38. pp. 157-170.

Shevera, M.-Protopopova, V.-Tomenchuk, M.-Andrik, E.-Kish, R. 2017: The first in Ukraine official regional list of invasive plant species of Transcarpathia [Перший в Україні офіційний регіональний список інвазійних видів рослин Закарпаття]. - Вісник НАН України, 10. pp. 53-61. https://doi.org/10.15407/visn2017.10.053

STANDOVÁR T. (szerk.) 2012: Erdôk a világban, Európában és Magyarországon. - Országos Erdészeti Egyesület, Erdészeti Lapok, 147. (1.) különszám. 36 p.

SZanyi Sz.-Katona, K.-Bernát, N.-Tamási, K.-Molnár, A. 2015a: A Nagydobronyi Vadvédelmi Rezervátum (Kárpátalja, Nyugat Ukrajna) gyepeinek flórájáról. - Tájökológiai Lapok 13. pp. 1-8.

SZANYI, SZ.-NAGY, A.-VARGA, Z. 2015b: Butterfly assemblages in fragmented meadow habitats of the PreCarpathian lowland (Bereg Plain, SW Ukraine). - Applied Ecology and Environmental Research 13. pp. 615-626. https://doi.org/10.15666/aeer/1303_615626

SZANYI SZ.-SZÓ́CS,L.-CSÓKA GY.-VARGA Z. 2015C: A Beregi-sík Noctuoidea (Lepidoptera: Macroheterocera) faunájának állatföldrajzi és ökológiai jellemzése. - Állattani Közlemények 100. pp. 89-100. https://doi.org/10.20331/AllKoz.2015.100.1-2.89

SZANYI, SZ.-NAGY, A.-VARGA, Z. 2016: Comparison of Macroheterocera assemblages of four forests in the Bereg Plain (Hungary, Ukraine). Biologia, Section Zoology 71. pp. 1281-1291. https://doi.org/10.1515/biolog-2016-0154

Ungvári Állami Erdőgazdaság 2019: Ungvári Állami Erdőgazdaság erdőállománya, erdészetek. https://uzh-lishosp.com.ua/napryam/lisokulturne-vyrobnytstvo/

UNGVÁRY R. 2016: Névterek és földrajzinév-tárak. Észrevételek a Magyarország Földrajzinév-tára és a nemzeti földrajzi névtér jövőbeli fejlesztéséről. Tudományos és Múszaki Tájékoztatás 2016/4. pp. 135-157. 


\section{KRÓNIKA}

\section{MARCZell GyöRGY emlékezete (1871-1943)}

MARCZELL GYÖRGY az Osztrák-Magyar Monarchia egyik legnagyobb városában, Pozsonyban született 150 éve, 1871. április 10-én. 1889. június 1-én tett érettségi vizsgát egy helyi reáliskolában. Egyetemi tanulmányait 1894-ig a Budapesti Egyetem bölcsészkarán végezte, majd belépett az Országos Meteorológiai és Földmágnesességi Intézetbe. Konkoly-Thege Miklós pártfogásának köszönhetően először a kiskartali csillagdában dolgozott.

Tervei alapján építették fel az ógyalai meteorológiai obszervatóriumot. A dobsinai jégbarlangban észlelóállomást állított fel, így megfigyelhette a barlang hőmérsékleti viszonyait. 1908-ban, amikor a Magyar Földrajzi Társaság elindította a Tátra Obszervatórium mozgalmat,
Konkoly felkérte Marczellt a Sonnblick, Säntis, Zugspitze, Obir hegyi obszervatóriumok telepítéséhez szükséges terepbejárásokra, emellett helyszíni szemlét tartott a Magas-Tátra összes szóba jöhetô csúcsán is. Tanulmányútjairól nyomtatásban is megjelent útijelentésekben számolt be.

MARCZELL GYÖRGY nevéhez fűződik az első magyarországi szélmérő ballon hitelesítése, amely 1913-ban száll fel. Ezzel kezdetét vette a hazai sztratoszféra-kutatás. Az első világháborúban magasságmérőket hitelesített és szélméréseket is végzett.

A Trianoni békediktátum után, amikor hazánk erdő borította területei nagy részét elveszítette, Marczell az Alföldön, Szegeden (1922) és a Hortobágyon (1927) telepített erdőkben vég-

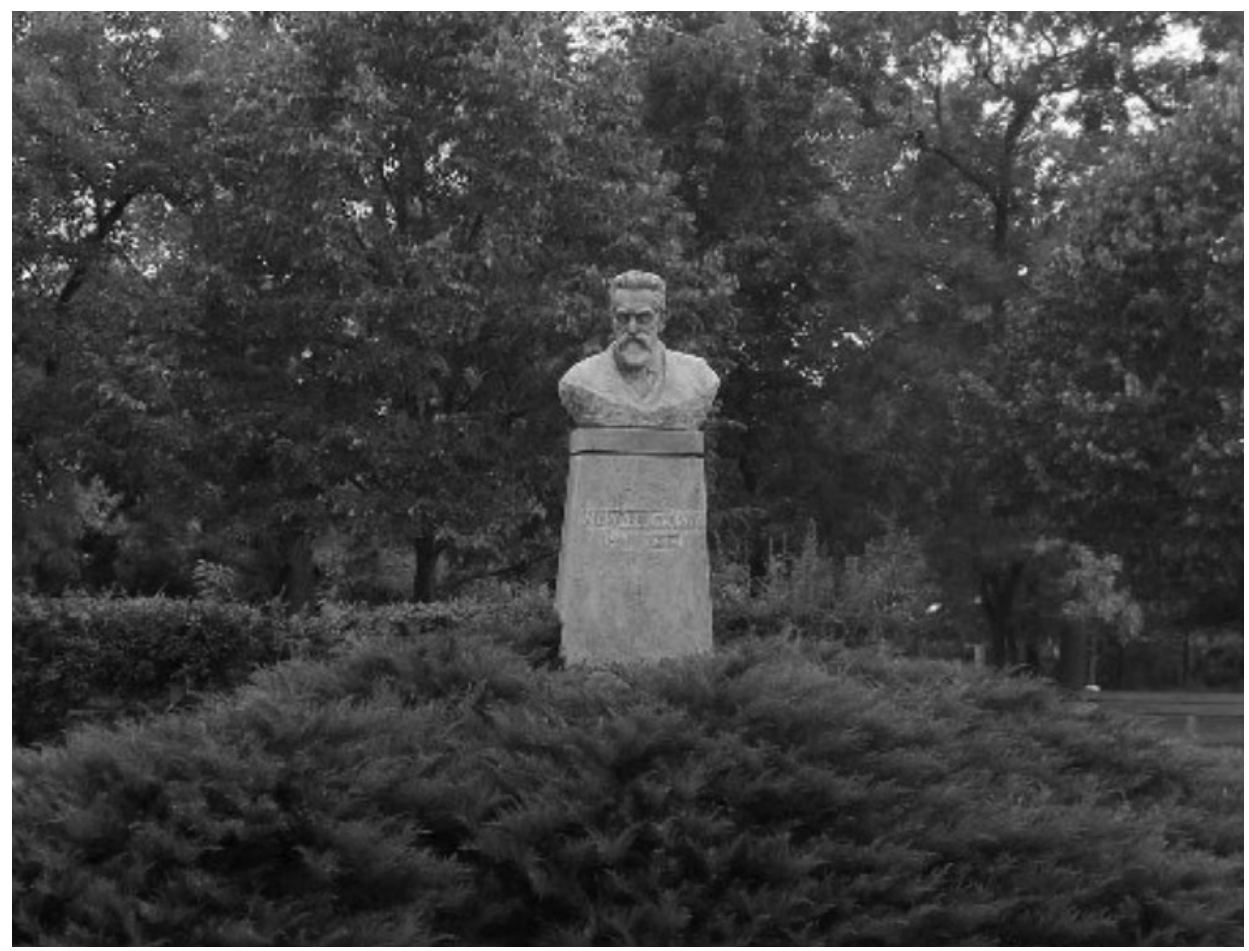

1. kép Marczell György mellszobra. Forrás: a szerző saját felvétele. 
zett szélmérésekkel bizonyította az erdő szélvédő hatását.

Az első világháború után, 1927-ben aligazgatója, majd 1933-tól igazgatója lett a Budapesti Meteorológiai Intézetnek. Az intézetbe 1934-es nyugdíjba vonulása után is rendszeresen bejárt és a fiatalok tanácsadója lett.

MARCZELL GYÖRGY a mikroklimatikus megfigyelések matematikai alapon való feldolgozásának első hazai múvelője volt. Elsőként figyelte meg hazánkban a földi áramlatokat, a légköri elektromoságot, valamint fontos szerepet töltött be a napsugárzással kapcsolatos kutatásokban is. Cikkeit „Az Időjárás” közölte 1897-től 1942-ig, a folyóiratban összesen harminc írása jelent meg.
Több tanulmánya látott napvilágot a Földrajzi Közleményekben is.

A Magyar Meteorológiai Társaság választmányi, majd levelező tagja, a Magyar Földrajzi Társaság levelező tagja, az Organisation Météorologique Internationale Magaslégkörkutató Bizottságának tagja volt.

MARCZELL GYÖRGY 1943. február 1-én halt meg Budapesten. Névadója volt a Meteorológiai Szolgálat 1952-ben Pestszentlőrincen felépült létesítményének, jelenlegi elnevezése szerint a Marczell György Főobszervatóriumnak. Az intézmény kertjében 1957. október 4-én avatták fel mellszobrát (1. kép).

HÁGEN ANDRÁS 


\title{
IRODALOM
}

\author{
GÁBRIS GYULA (szerk.): \\ 150 éves Magyarország elsố földrajz tanszéke \\ ELTE TTK Földrajztudományi Központ, Budapest, 2020, 214 p.
}

Magyarországon a tudománytörténetnek sajnálatosan nincs különösebb elismertsége és rangja, ezért kevesen múvelik és foglalkoznak vele. Ez bizonyos fokig érthetô, hiszen ma csak az számít tudósnak, aki legalább havonta ír egy angol nyelvú cikket, $n+1$ hivatkozása, impakt faktora, Hirsch-indexe és egyéb tudománymetriai mutatója van, ilyen ,pontokat” viszont egy tudománytörténeti munkára nem adnak, ráadásul kis hazánkon kívül megjelentetni sem lehet, mert ki a csudát érdekelhet a világban egy magyar szakmatörténet? Ezért különösen méltánylásra érdemes, hogy a földrajztudománnyal és földrajzoktatással foglalkozó elsô magyarországi egyetemi tanszék megalapításának jubileumi évfordulója alkalmat adott a földrajz hazai története egy újabb szeletének alaposabb megismerésére. Az ötletgazda és főszerkesztő GÁBRIS GYULA érdemeit e téren nem lehet eléggé dicsérni: mérhetetlen sok idót áldozott arra, hogy ez a munka összeálljon, amiben nagy segítséget kapott PROBÁLD FERENCtôl is - mindkettőjüknek ezer köszönet érte. Természetesen a köszönet azoknak is jár, akik egy vagy több életrajz megírásával hozzájárultak a könyv elkészülttéhez, valamint tördeléséhez, technikai kivitelezéséhez.

A könyv tartalmát a borító „, fülszövege” tökéletesen összefoglalja, idézzünk ebből: „Hunfalvy János 1870-ben egyetemi tanári kinevezést kapott a pesti tudományegyetemen felállított «egyetemes és összehasonlító» földrajzi tanszékre. Ez volt a világon a negyedikként alapított földrajz tanszék. A jubileumi év jó alkalom arra, hogy visszatekintve egyetemünk földrajz oktatásának az alapítástól számított 150 évére, bemutassuk történetét és megörökítsük a földrajz tanárainak és tudományos eredményeinek emlékét".

A könyv lényegében három részből épül fel, két szöveges főfejezetből és egy képgyújteményből.

Az Előszót követô első rész, amely A földrajzoktatás rövid története a budapesti tudományegyetemen címet viseli, egy valóban rövid, de alapos és tartalmas összeállítás, amely többet is nyújt annál, mint amit a cím sejtet. Az utolsó magyar kozmográfiától és a természettudományok 17. századi oktatásától kezdődően jócskán visszatekint az első tanszék alapítását megelőző évszázadokra, és nyugodtan kijelenthető, hogy a könyv egyik kiemelkedő része az első tanszék megalapítását megelőző mintegy 200 év jelentôsebb geográfusi és földrajzoktatási tevékenységet végzett személyei munkásságának lexikon-tömörségú ismertetése, számos szemléltető ábra kíséretében. Ezt követően a Hunfalvy-féle tanszék alapításától kezdve napjainkig áttekinti a budapesti egyetemi földrajzoktatás szervezeti kereteit (amire jellemző, hogy az első Földrajzi Intézet 1891-1961 között 70 évig állt fenn, a Földrajzi Tanszékcsoport nevú szerveződés már csak 45 évig, 2006-ig, amikor is a földrajzoktatás önálló szervezeti kerete meg is szúnt, és az utolsó 15 évben már csak egy része lett egy nagyobb intézetnek). Az áttekintést követően az utolsó mintegy 60 év részletesebb tárgyalást is kap, mégpedig a hatvanas években megszerveződött három ,régi” tanszék, majd az új intézetesítéssel együtt 2006-ban megszerveződött negyedik tanszék történetének ugyancsak átfogó jellegú ismertetésével.

Nem lehet eléggé dicsérni ezt a tartalmas áttekintést, amelynek szinte minden része rendkívül sok érdekességet és feltehetően bármely olvasó számára rengeteg újdonságot nyújt. Tisztelet a szerzőknek azért is, mert a hallatlan gazdag eseménytárból jó érzékkel válogattak, kirajzolódik belőlük egyes időszakok sokszor meghatározó történelmi háttere, és említésre méltó bizonyos emberi gyengeségek finom, többnyire árnyalt ábrázolása is. Külön is szomorú érdekesség az 1956-os forradalom és szabadságharc utáni tisztogatások korabeli jegyzőkönyvének ismertetése.

Ez az első rész tartalmazza a földrajztanárképzés elmúlt másfélszáz évének történetét is, ami a közoktatás II. világháború utáni átszervezését 
követôen az egyetemi képzésben a középiskolai korosztályt (tehát leegyszerúsítve a 14-18 éveseket) tanító tanárok képzésére korlátozódott, míg a 10-14 évesek szaktárgyainak oktatására tanárképző főiskolákat alapítottak. Az egyetemi tanárképzés azonban akkoriban többet is jelentett, mint ma, hiszen ha valaki ,földrajzos” akart lenni, akkor a geográfusképzésnek a kilencvenes években bekövetkezett megalapításáig közel öt évtizeden át csak földrajztanár szakra felvételizhetett. Közben 1974-ben Budapesten is alapítottak egy tanárképző főiskolát, amely a hagyományos jogi, bölcsészettudományi és természettudományi karok mellett hamarosan az ELTE negyedik karává vált, így az ELTE-n belül két külön helyen is folyt földrajztanárképzés, a könyv ennek a főiskolai kimenetű képzésnek a történetét is ismerteti. A bolognai rendszerre áttéréssel újra egységes lett a tanárképzés, de a súlyos hibákkal terhelt új - ahogy akkoriban maró gúnnyal nevezték: másfélszakos - rendszer bevezetése totális káoszt hozott, és a természettudományok területén a tanári pálya iránti érdeklődés radikális csökkenését eredményezte. Bár más szakokhoz képest az ELTE-n a földrajztanárképzés viszonylag jobban átvészelte ezt az időszakot, azért mégis nagy megkönnyebbülést jelentett, amikor az értelmetlen bolognai típusú tanárképzési rendszer helyébe a ma is élő ún. osztatlan tanárképzés lépett.

A könyv rövid, de tömör áttekintést nyújt a geográfusképzés közel 30 évéről, valamint a viszonylag rövid időre visszatekintő új típusú doktori képzésról is, utóbbit részletes adatokkal kiegészítve. Végül ez az első rész két, eltérő jellegú alfejezettel zárul, az egyik az egyetemi földrajzoktatás helyszíneinek képekkel illusztrált bemutatása, a másik az első száz év alatt létrehozott fényképtár hányatott sorsának ismertetése, mindkét alfejezet mondanivalója bőséges fényképanyaggal lett alátámasztva, többek között egykori Lóczy-és Cholnoky-fotók is nagy számban láthatók.

A könyv második része egyfajta „Ki kicsoda" jellegú személyi adattár. A tanszékalapító Hunfalvy Jánostól napjainkig terjedően 112 életrajzot közöl. A szerkesztő azt az eljárást követte, hogy az adattárat 70-30\%-os arányban megosztva két részre osztotta: a már elhunyt, illetve élo,, de nyugdíjas vagy máshol dolgozó oktatók, valamint a még aktív tanszéki alkalmazottak tárgyalására, ráadásul előbbieket születési éveik szerint rendezi, utóbbiakat tanszékenként ábécében tárgyalja, de a tanszékvezetőket ebből a sorrendből kiemelve az élre helyezi. Természetesen ez is lehet egy rendezői elv, hiszen a „régiek” esetében a nagyjából egy időben a pályán lévők kerültek többé-kevésbé egymás mellé (ennek követését a könyv első részében közölt 10. ábra ,,idővonala" is segíti); ezt el lehet fogadni, de talán mégis célszerűbb lett volna és könnyebb használatot tett volna lehetôvé egy hagyományos ábécésorrend mindkét esetben. Bár a szerkesztő törekedett a viszonylag egységes bemutatásra, mégis érthetően egyrészt a tárgyalt személy jelentőségétől, másrészt az életrajzíró megközelítésétől függően a szócikkek hossza igen eltérô. Minden életrajzhoz tartozik egy fénykép is. HUNFALVY JáNOS, LÓCZY LAJOS, CHOLNOKY JENÔ nevét bizonyára mindenki ismeri és CZIRBusz GÉZA, THIRRING GusZTÁV, KöVESLIGETHY RADÓ, JANKÓ JÁNOS vagy éppen StrömPl GÁBOr, HÉzSER Aurél, Haltenberger Mihály, LitTKe AurÉl neve is ismerős azoknak, akik a régebbi Földrajzi Közleményeket forgatták, vagy olvasgattak a Magyar Földrajzi Társaság történetéről. De valljuk be, hogy Anderkó Aurél, Steiner LaJos, Schwalm Amadé, Balogh Margit vagy HarMOS ELEONÓRA személye aligha ismert e sorok olvasói előtt - már csak emiatt is érdemes a könyvet forgatni. Ami pedig a háború utáni korszak oktatóit illeti, vannak közöttük, akik méltán kerültek a földrajztudomány nagyjai sorába, vannak, akik szorgalmas, becsületes munkájuk révén megérdemlik a visszaemlékezést, és sajnos vannak, akik az akkori politikai rendszer kegyéből lehettek egyetemi oktatók - bár utóbbiak egyike-másika is tudott idővel érdekesen és színesen oktatni. Sajnos a terjedelmi keretek nem tették lehetővé 150 év összes oktatója életrajzának megjelentetését, így az egyes korosztályok érthetően hiányolhatnak olyan személyeket, akik az ó egyetemi éveik alatt tanáraik voltak. Minden válogatás természetszerúen szubjektív, és említsük meg, hogy nem csak a szerkesztőn múlt, ki szerepel a kötetben és ki nem.

Végül az utolsó részben kereken 50 fénykép között tallózhat az érdeklődő. A képeken az 1900-as évek elejétől szinte napjainkig terjedôen mintegy 110 év különbözó időszakainak jellegzetes felvételei sorakoznak, rajtuk a szakma egykori óriásaitól a régi és a modern idők diákcsoportjain át a kutatási tevékenységek ábrázolásáig terjedôen számos különböző téma jelenik meg - ELTE-s öregdiákok nagy izgalommal kereshetik egykori önmagukat... Ha egyetlen kritika említhetô, akkor az az, hogy számos fénykép az eredeti állapotában lett közölve. Ez 
- mondhatnánk - így tisztességes, de manapság a rossz minőségú képek feljavítására számtalan technikai lehetőség van, amivel jó lett volna élni, és alkalmazásuk az olvasó számára is elónyösebb lett volna.

Összességében nyugodt szívvel ki lehet jelenteni, hogy kiváló és nagy érdeklődésre jogosan számot tartó alkotás született. A könyv az idősebb öregdiákok körében máris óriási sikert aratott; ezt azok a visszajelzések igazolják, amit e sorok írója személyesen kapott sokaktól. Böngészését azonban azoknak is ajánlom, akik nem az ELTE-n végeztek, hiszen - mint e könyvismertetés elején már szó esett róla ez egy tudománytörténeti kézikönyv is, amely elősegíti a földrajz hazai történetének alaposabb megismerését.
A megjelenést követôen a visszajelzések alapján a szerkesztő egy javított és bóvített kiadást készített el. Ebben sikerült nyolc régi tanár életrajzát megírni, illetve bővült azon kollégák száma is, akik már máshol dolgoznak, de jelentôs szerepet játszottak az oktatásban. A hidrológus képzés ismertetésével is kiegészült a könyv. A függelékben az életrajzzal nem szereplő, elsősorban a mellékállású, a megbízott előadók, a nem oktató dolgozók és a fényképtárban lévő képeket készítők listája olvasható. Ez a második kiadás - fóként pénzügyi okok miatt - már csak elektronikus formában jelent meg. A könyv elérhető az ELTE Földrajz- és Földtudományi Intézetének honlapján, mindenkinek szívből ajánlom, érdemes elolvasni!

HoRVÁth GERGELY

\section{ERDŐSI FERENC: \\ A globalizálódott tengerhajózás és a világkereskedelem ELKH Közgazdaság- és Regionális Tudományi Kutatóközpont Regionális Kutatások Intézete, 2021, Pécs, 467 p.}

A közlekedésföldrajzi kutatások immáron 87 éves hazai doyenje, ERDősI FERENC, aki nem csak több évtizedes kiemelkedő színvonalú tudományos munkásságáról, de rendkívül gazdag publikációs tevékenységéről is ismert, legújabb könyvében a világ tengerhajózásának a globális kereskedelem növekedésében játszott kulcsszerepével foglalkozik. A szerző enciklopédikus jellegú múvében nagy ívú áttekintést ad a tengeri áruszállítás hosszútávú alakulását befolyásoló természeti, közlekedéstechnikai és -logisztikai, valamint gazdasági tényezőkről, továbbá e tényezők mint rendszerelemek között érvényesülő bonyolult kapcsolatokról, azok idő- és térbeni változásairól.

ERDŐsI FERENC könyve több szempontból is egyedülálló tartalmú. Egyrész a célba vett szakterület olyannyira széles spektrumot ölel át, hogy ennek feldolgozására csak kevesen vállalkoznak, másrészt a szerző - a légiközlekedés fejlődésének területi folyamatait átfogó módon elemző két kötete után csaknem negyed évszázaddal - a tengerhajózás és a világkereskedelem időbeni változásainak főbb összefüggéseit tárja az olvasó elé. Ahogy akkor, úgy ezúttal is olyan tudományos múvet alkotott, ami hiánypótló és szakmailag igényes munka. A szerző mindezzel igen fontos gazdaságföldrajzi kérdést bont ki, hiszen a világkereskedelem $85 \%$-a a világtengereken bonyolódik, amely mellett minden más közlekedési ágazat teljesítménye eltörpül.
A könyv a tengerhajózás elemeiból építkezik, s igyekszik annak valamennyi szempontját áttekinteni. Kiemeli a kulcsfontosságú közlekedési ágazat terén végbement átfogó múszaki innovációt, ami átalakította a szakág teljes struktúráját. Megtudjuk, hogy milyen ütemben változik a világflotta méret- és kapacitásnövekedése, hogyan szakosodott tovább a hajópark összetétele és milyen új üzemanyagok, meghajtási módok segítik ma a gazdaságosabbnak vélt fuvarozást. A szolgáltatók körében új szervezeti formák alakultak, de a verseny a hajózási társaságokat is szövetségek létrehozására kényszerítette. Forgalomszervezésben az infokommunikációs technológiára alapozott, idő- és költségmegtakarítást szem elótt tartó (a légiközlekedés gyakorlatából is ismert) „hub and spokes” szállítási rendszer került előtérbe, ahol a csomóponti kikötők jelentősége értékelődött fel.

A könyvben külön hangsúly kap a konténerizáció, mivel a konténerhajózás rakományának mennyisége fontos mutatója a világkereskedelem konjunkturális helyzetének. Ezt támasztja alá, hogy - a szállított áruféleségek USD-ben számított összértékét tekintve - a világtengereken lebonyolódó áruszállítás 90\%-át már konténerhajók bonyolítják.

A szállítási tanulmányok két közös vonása, az empirikus adatokra való nagymértékú támaszkodás és az adatelemzési technikák intenzív 
használata. A szerző ennek az elvárásnak mindvégig igyekszik megfelelni. A kötetben található 147 táblázat adatsorai rendkívüli háttérmunkáról árulkodnak. Talán az átvett (és átszerkesztett) ábrák tartalma, minősége és jelkulcsrendszere is érdemelt volna pontosítást és nagyobb vizualitást.

Ugyanakkor a szerző visszatérően taglalja a geoökonómiai és geopolitikai kérdéseket is. Felhívja a figyelmet Kína térnyerésére, valamint Hongkong és Szingapúr nem mai keletû versenyére. A kelet-ázsiai-export két jelentős szétosztója ma sajátos versenyt fut. Hongkong növekszik ugyan, de messze elmarad Szingapúrtól, ami nem feltétlenül a fejlett délkelet-ázsiai városállam kizárólagos sikere. Kína áll a háttérben, hiszen amióta az egykori virágzó brit gyarmat, Hongkong Kína része lett, a hatalmas ország elsősorban a „saját” keleti kikötőit pozícionálja. Kína esete mindemellett több szempontból is izgalmas geopolitikai kérdés, elég, ha Grönlandra, Izlandra vagy a nyugat-atlanti térségre vonatkozó lépéseire tekintünk.

Két - szakmai értelemben jól illeszkedő fejezet is elemzi a kikötők helyzetét, ami ezáltal több figyelmet kap, mint ami a címből adódóan elvárható lenne. A már említett konténerizáció mellett a hagyományos és új kikötőiparok viszonya, a kikötők funkcionális fejlődésének sajátosságai, továbbá a kikötő-város-hátország kapcsolat viszonyrendszere került - számos példával, gazdasági adatokkal alátámasztva - kifejtésre. Rámutat azokra az elónyökre is, amelyet az ázsiai hubok európai és észak-amerikai versenytársaikkal szemben tanúsítanak, és megállapítja, hogy ennek kiegyensúlyozásához meg kellene birkózni az örökség korlátaival, hogy a hatékonyság kerülhessen előtérbe a földrajzi, gazdasági, intézményi struktúrákban. Ezek mindmind rendkívül fontos kérdések, és kapcsoltan részei is a tengerhajózás rendszerének, azonban a téma terjedelmét és relevanciáját tekintve akár egy újabb kötet kutatási anyagát képezhetné a jövő kutatói számára.

A szerző a hazai geográfusok közül gyakorlatilag egyedül járja - virtuálisan - a világtengereket, és szállítja olyan hitelességgel az információkat, mintha valóban megfordult volna Hong Kong és Szingapúr rakodó teraszain, vagy végighajózott volna a Panama-csatornán Panamaváros és Colón között. Bár nem végezhetett a köny vében leírt távoli helyszíneken terepmunkát, nem Sanghajból, Port Szaid-ból vagy Algecirasból gyújtötte össze a felhasznált, mérhetetlenül nagy és értékes anyagot, hanem lankadatlan szorgalommal és kitartással a szakirodalomból és a szakmai tartalmú médiafelületekről gyújtötte össze a könyvéhez szükséges lényeges információkat. „Nagyon nehezen lehetett összehozni a statisztikai sorokat, amire az összehasonlítás miatt szükség volt. Sokszor eltérő dimenziókat kellett átszámítani fáradságos munkával" - panaszolta. Főleg internetről dolgozott, emellett csak az elérhető szakkönyvek és több rangos folyóirat volt segítségére. Hatalmas ismeretanyag birtokában viszont nagy gondossággal szúrte ki a nem hiteles információkat, amiben egyaránt támaszkodhatott több évtizedes szakmai tapasztalatára és széles körú általános múveltségére.

ERDŐSI FERENC könyve nem optimista hangvételú. Tárgyilagos, kritikus és sokszor érezteti, hogy a jelenlegi folyamatok nem jó irányban haladnak. Állandósultak a világméretû gazdasági, társadalmi, szociális és környezeti gondok. Bírálja a gigantomániát, megemlíti a Szuezicsatorna múködését fenyegetô tényezőket, és kritikusan tekint a globalizmus ellentmondásaira. „A világban végbemenő átalakulás helyrehozhatatlan,... s talán még nagyobb baj, hogy erról nem vesz érdemi tudomást a döntéshozó, a szakma, a közember ... senki, ez nagyon elkeserít" - írja.

ERDŐSI FERENC ezen munkáját súlyos betegen fejezte be, mégis ez a kötet sokkal több, mint életjel. Ez a mú hiánypótlás, a szakma régi tartozása egy felértékelődô, ugyanakkor nagyon nehezen kutatható terület ismeretanyagának felszínen tartása érdekében. A szerző vallomása szerint a kertészkedés és a kávéházi beszélgetések kényszerú elmaradásával az aprólékos munkát követelő alkotás öröme maradt számára. Ám nem is ő lenne, ha az izgalmas szakmai kérdések nem foglalkoztatnák a jelenben is. Közéjük tartozik például a kockázatos tengeri útvonalak tanulmányozása, valamint a Fiume (Rijeka) és Trieszt versenyének történeti szempontú vizsgálata. „Utóbbi esetében ne felejtsük el Koper, Ravenna és Velence szerepét sem" - figyelmeztet!

Azzal a céllal, hogy minél többen megismerhessék a tengerhajózás és a világkereskedelem jövőbeni alakulása iránt felelősséget érző tudós gondolatait, ERDŐsI FERENC könyvével fontos kulturális missziót teljesít. Bár a kötet nem kerül kereskedelmi forgalomba, a szerző gondoskodik róla, hogy legújabb múvét ne csak a témát múvelő kollégák forgathassák haszonnal, hanem példányai hozzáférhetőek legyenek az egyetemeken és 
a különböző tudományos intézetek szakkönyvtáraiban is. „A globalizálódott tengerhajózás és a világkereskedelem" címú könyv elolvasását az izgalmas témakör iránt érdeklődőknek messzemenően ajánlom.

KUCSERA EMIL

\title{
MÁTYÁs SZABOLCS:
}

\section{Búnözésföldrajz}

\author{
Egyetemi jegyzet, Didakt Kiadó, Debrecen, 2020, 136 p.
}

Napjainkban a búnözés különböző formái tetemes gazdasági és társadalmi károkat okoznak, így az ellenük való eredményes fellépés fontos társadalmi célkitúzés. A földrajztudomány részét képező bűnözésföldrajz ennek egyik fontos eleme lehet.

MáTYÁs SZABOLCS egyetemi jegyzete minden tekintetben hiánypótló ennek a hazánkban oly méltatlanul elhanyagolt, alkalmazott tudománynak az életében. Mivel a bűnözésföldrajz mint „,burzsoá tudomány” a rendszerváltozás előtt tiltólistán volt, a jegyzet a gyakorlatban a hazai kriminálgeográfia három évtizede tartó reneszánszának egyik újabb eleme lehet.

A kötet alapvetôen magyar és német nyelvú szakirodalmak alapján meghatározza a bûnözésföldrajz fogalmát, de számos angol és francia munkát is hivatkozik a szerző. A búnözésföldrajz fogalma nem egyértelmú, mutatja ezt az is, hogy a szerző tizenhárom defincíciót sorol fel csak a magyar szakirodalomból, amelyek többé-kevésbé a bűnözésföldrajz szinonímái. A megközelítések között megkülönböztet kriminológiai, földrajzi és középutas típusokat.

Egy részletes tudománytörténeti áttekintésben megismerhetjük a bűnözésföldrajz 19. századi gyökereit, valamint a társadalomföldrajz által sokat hivatkozott chicagói szociológiai iskola kriminálgeográfiai dimenzióit. Kuriózumként megtudhatjuk azt is, hogy 100 évvel ezelőtti Chicago melyik városnegyedét uralták az ottani magyar szervezett bűnözők.

A szociológia és szociálgeográfia szempontjából kiemelkedő megállapítás, hogy „egy társadalmi réteg, ha nincs megfelelő kontroll alatt, nincs kapcsolata más csoportokkal, akkor nagyobb az esélye arra, hogy bűnelkövetővé váljon”. Ennek a veszélyhelyzetnek a megelózése földrajzi eszközökkel is elősegíthető. A bűnözésföldrajzi vizsgálatok többféle területi egységben történhetnek: nemzetközi, regionális, megyei, járási, települési és településen belüli szinteken. Nemzetközi szinten az összehasonlíthatóság fontos kérdés, hiszen más a statisztikai adatok gyújtésének módszertana, illetve az egyes országok büntetôtörvénykönyvei is eltéróen értelmezik a különböző tényállásokat. A geográfiai-kriminalisztikai megközelítés szerint tudományos szempontból az egyre kisebb egységeken történő vizsgálatok adják a legnagyobb segítséget bűnüldöző szervek számára.

$\mathrm{Az}$ érdeklődők, illetve az aktív rendőrségi állomány tagjai számára is fontos fejezet lehet a kriminálgeográfiai kutatások legfontosabb forrásait bemutató rész. Itt megismerhetjük a legfontosabb folyóiratokat, évértékeló jelentéseket és adatbázisokat (pl. Robotzsaru). Ezek egy része nyilvános, míg vannak csak a hatóság számára elérhető források. A szerző kiemeli az önálló, primer adatgyújjtés jelentőségét a bűnözésföldrajzi kutatásokban, így például a rendőri vezetőkkel történő szakmai konzultációkat vagy lakossági kérdőíves felméréseket. A statisztikai adatok forrásául hazai és európai rendszerek (Bűnügyi Statisztikai Rendszer, Európai Statisztikai Hivatal, KSH, ORFK térkép, TEIR, a Prevenciós Búnözés-statisztikai Adattár(PRESTAT) szolgálhatnak.

A kriminálgeográfia módszertanának talán legfontosabb eleme a bűnözési térképezés. A jegyzetből az olvasók kézikönyvszerúen megismerhetik a térképkészítés főbb szempontjait, különös tekintette a tematikus térképekre. Betekinthetünk a bűnözési térképek készítésének történetébe a korai, ún. ,gombostű” térképektől egészen a legmodernebb GIS megoldásokig. A modern bűnözési térképekről megtudhatjuk, hogy számos területen használhatók a mindennapi rendóri munkában, így a bűnmegelőzésben, a szolgálatszervezésben és az elemző-értékelő munka során, de akár a közrendvédelmi akciók területének meghatározásában vagy a járőrútvonalak megtervezésében is. A szerző újítása az „izokrimen" térkép, azaz az azonos búnelkövetési statisztikákkal rendelkező pontokat összekötő vonalakat ábrázoló térkép.

Izgalmas alkalmazási terület lehet az ún. földrajzi profilalkotás, vagy az építészeti búnmegelőzés, utóbbi fontos terület- és településfejlesztési, valamint településrendezési kérdéseket vet fel. 
A szerző érzékeny kérdéseket is feszeget, amikor arról értekezik, hogy a bűnözésföldrajzi térképek és egyéb eredménytermékek mennyire lehetnek nyilvánosak. Sajnos nem megfelelő kezekben ezek az információk súlyos veszélyeket is magukban hordozhatnak. Különösen érdekesek lehetnek szakmai szemmel a prediktív, megelőző rendszer lehetôségei, amelyeken keresztül akár a búncselekmények előre is jelezhetők. A terület megfelelő szabályozottságának hiányosságát mutatja ugyanakkor, hogy például a Robotzsaru informatikai rendszerhez nincs minden releváns államigazgatási szereplónek hozzáférése.

A földrajz hagyományos kategóriáit elevenítik fel a következő kriminálgeográfiai kulcsfogalmak: bűnelkövetôi vonzáskörzet, forró pontok és hideg pontok. Ez utóbbiak olyan dinamikus földrajzi képződmények, amelyekre koncentrálva (ún. forró pont rendészet) hatékonyabb bűnmegelőzés és bűnüldözés valósítható meg. A dinamika megértését segítheti az ún. „betört ablakok elmélete", azaz amikor egy-egy kisebb bűncselekmény a jövőben nagyobbak elkövetését motiválhatja az adott területen.

Ezek alapján magától értetődő, hogy a településszerkezetnek fontos bűnözésföldrajzi vetületei vannak. A kriminalitási különbségeket a speciális szubkultúrák esetében a szerzố a klasszikus, humánökológiai városmodellekhez rendelt kriminálgeográfiai jellemzőkkel mutatja be. Külön figyelmet fordított ezen belül néhány speciális hazai jelenségre, mint a lakótelepek, vagy a zártkertek társadalmi jellegzetességeire, illetve bünözési helyzetére.

A bűnözés természeti és társadalmi indikátorain túl a földrajzi tényezőknek a rendészet területére való integrálása fontos feladat. A szerző javaslatot tesz ezeknek a tényezőknek a körére, így a következő faktorok bűnözésföldrajzi relevanciájáról olvashatunk részletesebben: demográfiai és népességföldrajzi tényezők, a település lakosságszáma, funkciója és méret, a népesség iskolai végzettsége, az oktatási intézmények jelenléte, a településszerkezet sajátosságai, közlekedésföldrajzi adottságok és gazdasági adatok.

A jegyzet egyik fejezetében a gyakorlati bűnözésföldrajzi kutatás egy sablonjának a leírását találjuk, beleértve azokat a statisztikai mutatókat, amelyek alkalmasak lehetnek a területi különbségek leírására. Ez a módszertani rész kutatásmódszertani segítséget nyújt azoknak, akik ezen a területen dolgoznak.
A szerző fontos megállapítása, hogy a magyar területfejlesztési törvény nagy hiányossága, hogy nem foglalkozik a bűnözés és búnüldözés szempontjaival. Ennek a hibának a korrigálására MÁTYÁs SzABolcs iránymutatást ad egy olyan, a közbiztonságra is fókuszáló, lakótömb alapú településtervezés létrehozására, amelyben a közösségi kultúrának és a társadalmi kohéziónak is fontos szerepe van. A hazánkban is ismert „szituációs bűnmegelózés” keretében ezek a lépések elvezethetnek védhetô terek kialakításához. Ennek keretében a rendőrség kötelékében új pozíciók létrehozása válhat szükségessé, mint például a design tanácsadó, vagy az építészeti összekötő tiszt. Ezen túlmutatóan a szerző javasolja egy komplex bûnmegelőzési koncepció, vagyis egy új településfejlesztési dokumentum kialakítását is.

A kötet utolsó részében olyan speciális területek bűnözésföldrajzi problémáit tekinti át a szerző, mint például az államhatárokhoz kapcsolódó bűncselekmények. A korábbi évek uralkodó felfogása szerint a határ nem elválaszt, hanem összeköt. Ugyanakkor a közelmúlt migrációs válsága, illetve a jelenlegi COVID 19 világjárvány nagyon izgalmas kérdéseket vet fel ezen a téren. A migrációs földrajzi elemzések elvégzése Magyarország szempontjából az ország fekvése miatt kulcsfontosságú feladat. Ebben nemcsak határrendészeti, de természet- és társadalomföldrajzi tényezők szerepe is egyaránt fontos. Az olvasó számára újdonság az egyes, határokhoz kapcsolódó büncselekmények időbeli eloszlásának vizsgálata. Megtudhatjuk, hogy az embercsempészet nemcsak éjszakai múfaj, ugyanakkor leggyakrabban kedden és pénteken fordul elő.

A határokhoz kapcsolódó kutatások mellett speciális terület a szervezett bűnözéshez kapcsolódó bűnözésföldrajzi vizsgálatok rendszere. Ezek földrajzilag Magyarországon a nagyvárosok (különösen a fóváros), a főváros környéki agglomeráció, a déli határszakasz és az autópályák környékén koncentrálódnak.

A bűnözésföldrajz gyakorlati alkalmazása a rendôrség reagáló képességének és bűnügyi eredményességének a javulását eredményezheti. A geográfusok több országban, így Németországban, Franciaországban és az Egyesült Királyságban is folyamatos bünözésföldrajzi vizsgálatokat végeznek, így segítve a rendőrség munkáját. A bû́nmegelőzés és a forrópontok kutatása hasznos lehet nemcsak a hallgatók, de 
az aktív állomány számára is. A búnözésföldrajz tehát egy újabb szakterület, amely bizonyítja a geográfia gyakorlati hasznát és jelentőségét a modern társadalom életében. Sajnos Magyarországon a búnözésföldrajz és a geográfia még nem érte el azt a társadalmi megbecsülést, amelyet megszolgált, de remélhetőleg hazánk is mielőbb csatlakozik a fent említett progreszszív országok köréhez. Mindenesetre MáTYÁs SzABOLCs Bűnözésföldrajz című egyetemi jegyzete jelentősen hozzájárul a búnözésföldrajz elméleti alapjainak lerakásához és gyakorlati alkalmazhatósághoz.

PATKÓs CsABA 


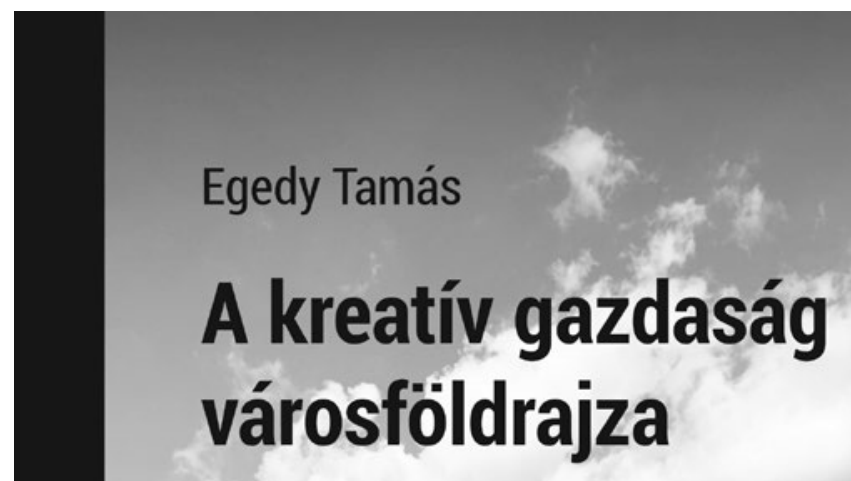

a budapesti agglomeráció példáján

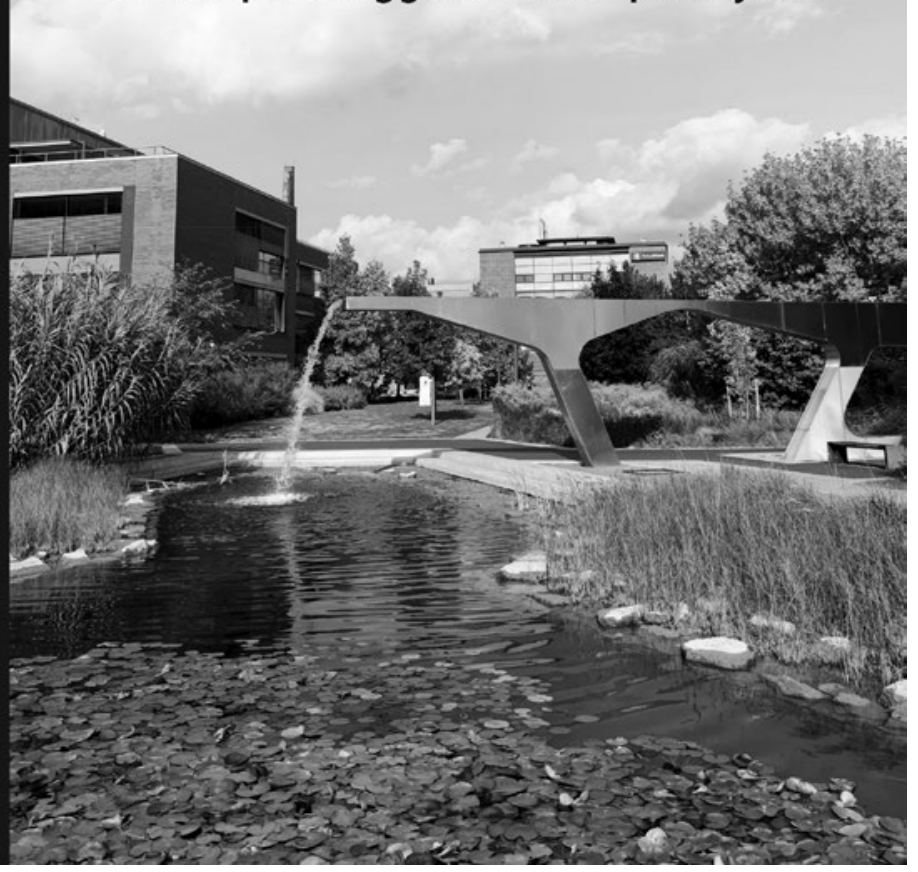

EGEDY TAMÁS:

\section{A kreatív gazdaság városföldrajza a budapesti agglomeráció példáján}

Csillagászati és Földtudományi Kutatóközpont, Budapest, 2021, 167 p.

Az elmúlt évtizedekben a tudás, a kreativitás és az innováció szerepe felértékelődött a városok versenyképességében. Nem véletlen, hogy a kreativitás, a kreatív gazdaság és a városok fejlődése egyre jobban összefonódott. Fokozatosan átalakult a városok társadalma és gazdasága, valamint a városrégiók fizikai környezete és térbeli megjelenése. A szerző a budapesti agglomeráció példáján keresztül mutatja be a kreatív gazdaság fejlődésének városföldrajzi hatásait.

További információ: magyar.arpad@csfk.org 


\section{Szerzőink figyelmébe!}

Kérjük Szerzőinket, hogy megjelentetésre szánt cikkük, tanulmányuk elkészítésekor kövessék a Földrajzi Közlemények tanulmányainak formai felépítését és az alábbi szempontokat vegyék figyelembe!

\section{Szöveg}

A tanulmányt a szerző az elektronikus beküldő felületen keresztül töltheti fel a Földrajzi Közlemények rendszerébe. A felület elérhető a Magyar Földrajzi Társaság honlapján, a Földrajzi Közlemények oldalán. Kérjük Szerzőinket, hogy tanulmányukat a formai követelményeknek megfelelően formázva küldjék be! Az anyag terjedelme legfeljebb 40 ezer karakter lehet szóközökkel. A tanulmányhoz 10-15 soros összefoglalót és 3-5 kulcsszót mellékeljenek angol nyelven! A szövegben lábjegyzetet csak kivételes esetben alkalmazzanak, végjegyzetet ne használjanak! A tanulmányokban 3 fokozatú címrendszer használható (fejezetcím, elsőrendû alcím, másodrendú alcím).

\section{Szakirodalmi hivatkozások}

A hivatkozás formája: A szerzó neve (keresztnevének rövidítésével) és a megjelenés éve. A szövegkörnyezettől függően: TóTH Z. (2018) vagy (TóTH Z. 2018). Külföldi szerző publikációjára történő hivatkozáskor a név két tagja közé vessző kerül: (HARRISON, M. 2017).

Többszerzős hivatkozás esetén a nevek közé nagykötőjel kerül: (HoRváth S.-SOLYMOS G. 2016). Ha a hivatkozott munkának háromnál több szerzője van, csak az elsőnek a neve szerepeljen: (KovÁcs B. et al. 2013). Ha adott szerzőnek egy évben több publikációjára történik hivatkozás, akkor az évszámhoz a, b stb. írandó: (Тóтн Z. 2012a).

Felsorolásszerú hivatkozások esetén az egyes - időrendbe és nem ábécé-sorrendbe rendezett tételeket pontosvessző választja el: (NÉMETH P. 2008; HORVÁTH V. 2006).

\section{Irodalomjegyzék}

$\mathrm{Az}$ értekezés végén a felhasznált munkák jegyzéke szerzők szerint ábécé-sorrendben, ezen belül időrendben legyen! Az Irodalomjegyzékben a tanulmányban hivatkozott minden mú könyvészeti adatának szerepelnie kell.

\section{A különbözó jellegú kiadványok mintája}

Könyv: MendöL T. 1963: Általános településföldrajz.-Akadémiai Kiadó, Budapest. 567 p.

Könyvfejezet: SzÉKELY A. 1998: A periglaciális felszínformálás. - In. BORsY Z. (szerk.): Általános természetföldrajz. Nemzeti Tankönyvkiadó, Budapest. pp. 356-421.

Folyóirat: BELUSZKY P. 2005: A mezóvárosok és az ,alföldi út”. - Földrajzi Közlemények 53. 1-2. pp. 31-46.

KrolopP E.-SÜMegi P.-Kuti L.-HerteLENDI E.-KordOS L. 1995: Szeged-Öthalom környéki löszképződmények keletkezésének paleoökológiai rekonstrukciója. - Földtani Közlemények 125. 4. pp. 309-361.

\section{Ábrák, fényképek, táblázatok}

A tanulmányhoz tartozó ábrákat, fényképeket (a törzsszövegben a források pontos megjelölésével, angol és magyar nyelvú aláírásokkal) külön fájlokban kérjük feltölteni! Wordbe beszúrt illusztrációt nem fogadunk el! A szövegben feltétlenül szerepeljen rájuk utalás, hivatkozás.

\section{Ábrák}

Az ábrákat eps vagy ai, esetleg egyéb olyan vektorgrafikus formátumban kérjük, amelyet az Adobe Illustrator szoftver kezelni, importálni képes. Vegyék figyelembe, hogy a jpg és tif formátumban beküldött ábrák nehezen szerkeszthetők. Az ábrákon csak a legszükségesebb felírások (földrajzi nevek, méretek, a jelmagyarázat sorszámai, betújelzései stb.) szerepeljenek, minden egyéb információ (cím, a sorszámok, betújelzések magyarázata stb.) az ábraaláírásba kerül. Az ábrákban szereplő felírásoknál kérjük egységesen a Times betútípust, valamint 8-10 pontos betúnagyságot alkalmazni nyomdai méret esetén. Az ábrákon az alkalmazott koordinátarendszerek stílusa, beosztásai, mértékegységei egységesek legyenek! Az ábrák fontjait görbékké konvertálhatja a szerző, megelőzve így az utólagos szerkesztést. A fekvő ábra szélessé- 
ge 70-125 mm között változhat, az álló ábrák maximális magassága $182 \mathrm{~mm}$ lehet. A szerző úgy segítheti legjobban szerkesztőségünk munkáját, ha a fenti kérések figyelembevételével úgy és olyan méretben küldi be az ábrákat, ahogyan azokat nyomtatásban látni szeretné.

\section{Fényképek}

A fényképeket kérjük tif vagy jpg formátumban beküldeni! A fotókat javasoljuk a felhasználni kívánt nyomdai méretben 300 dpi-vel szkennelni. Kisebb méretû fényképet, diát nagyobb felbontással kell szkennelni.

\section{Táblázatok}

A táblázatokat Word (doc), Excel (xls), vagy eps formátumban várjuk szerzőinktől, a jpg és tif formátumot szíveskedjenek mellőzni! Keretezés és rácsozás felesleges: elválasztó vonalak csak a fejlécben, illetve az oszlopok között szükségesek.

Felhívjuk Szerzőink figyelmét, hogy a tanulmányok beküldési lehetősége e-mailben és egyéb adathordozón megszűnt. A tanulmányok beküldéséhez a folyóirat elektronikus felületét vegyék igénybe:

http://ojs3.mtak.hu/index.php/fk/login 


\section{MAGYAR FÖLDRAJZI TÁRSASÁG \\ ALAPÍTVA: 1872}

\section{Tisztikar}

Elnök: LóCZY DÉNES egyetemi tanár

Tiszteletbeli elnök: PAPP-VÁRY ÁRPÁD ny. egyetemi tanár

Alelnökök: EGEDY TAMÁs tudományos fómunkatárs, egyetemi docens

NEMERKÉNYI ZsOMBOR tudományos munkatárs

Fótitkár: JENEY LÁsZLó szakosztályelnök, egyetemi docens

Titkár: SzIKSZAINÉ RÁCZ TímEA iskolai földrajztanár

Felügyelóbizottság: Boros LaJos, KuBA GÁBOR, Michalkó GáBOR

\section{Választmány}

AUBERT ANTAL szakosztályelnök, intézetigazgató

BERNEK ÁGNES szakosztályelnök, föiskolai tanár

BUJDOSÓ ZOLTÁN főiskolai tanár

CSIZMADIA NORBERT szakosztályelnök

DÁVID LÓRÁNT DÉNES osztályelnök, egyetemi tanár

FARSANG ANDREA egyetemi docens

FRISNYÁK SÁNDOR osztályelnök, ny. egyetemi tanár

GERHARDTNÉ RUDLI ILONA ny. középiskolai tanár

GÖNCZI SÁNDOR osztályelnök, főiskolai docens

GRUBER LÁSZLó középiskolai tanár

GYENIZSE PÉTER egyetemi docens

GYŐRI RÓBERT egyetemi docens

GYURICZA LÁSZLÓ osztályelnök, egyetemi docens

HEVESI ATTILA osztályelnök, ny. egyetemi tanár

HUSZTI ZsOLT osztályelnök, intézetigazgató

KARANCSI ZOLTÁn tszv. egyetemi docens

KARÁTSON DÁvID szakosztályelnök, tszv. egyetemi tanár

KIss EDIT Éva tudományos tanácsadó, egyetemi tanár

KLINGHAMMER IsTVÁN szakosztályelnök, akadémikus

KoPEK ANNAMÁRIA osztályelnök, osztályvezető

KovÁCs ZoLTÁN akadémikus, egyetemi tanár, IGU Magyar Nemzeti Bizottságának elnöke
KUbASSEK JÁNos Magyar Földrajzi Múzeum igazgatója

KUNOS GÁBOR szakosztályelnök, villamosmérnök

LENNER TIBOR osztályelnök, tszv. egyetemi docens

LERNER JÁNOS szakosztályelnök

M. CSÁSZÁr ZsuZSANNA osztályelnök, egyetemi docens

MÁJAI Csaba osztályelnök

MAKÁDI MARIANN szakosztályelnök, főiskolai docens

MuCSI LÁSZLÓ osztályelnök, egyetemi docens

NAGY BALÁZs egyetemi docens, a Földgömb fószerkesztője

NAGY GyUla egyetemi adjunktus

PÁL VIKTOR egyetemi docens

PAP NORBERT osztályelnök, tszv. egyetemi tanár

RADICS ZsOLT egyetemi adjunktus

SIMON GYÖRGY középiskolai tanár

SUBA JÁNOS szakosztályelnök, térképész

SZŐLLÓSY LÁSZLÓ középiskolai tanár

SZÖRÉNYINÉ KUKORELLI IRÉN osztályelnök, tudományos tanácsadó, egyetemi tanár

TEPERICS KÁROLY osztályelnök, egyetemi adjunktus

TIMÁR JUDIT osztályelnök, tudományos főmunkatárs

TóTH ANTAL osztályelnök, föiskolai docens

TÖMPE LÁsZLÓ szakosztályelnök, középiskolai tanár

VIZI IsTVÁN osztályelnök

\section{A Közgyúlés által megválasztott tiszteleti tagok a Magyar Földrajzi Társaság Választmányának örökös tagjai.}




\section{Értekezések / Studies}

Konkoly-Gyuró Éva-VAszócsiK VilJa-CSORba PÉTER-Schneller Krisztián-Jombach SÁndor -Boromissza Zsombor-Erdei Tímea-Keszhelyi Ákos-Balázs Pál-Kiss Dániel

-TeleKi MóniKa-BÁNHIDAi AndRÁs-Csószi MóNiKA: Az országos tájkarakter-elemzés kezdetei Magyarországon / The beginning of the nation-wide landscape character assessment in Hungary

Veress Márton: A Nyugat-Mecsek felszíni karsztja / The surface karst of the Western Mecsek .....

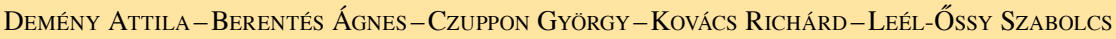

-SURÁNYI GERGELY: Nyitni vagy nem nyitni? - Pilisi barlangok szellőzöttsége

a geokémiai adatok tükrében / To open or not to open? - Ventilation in the Pilis caves in the light of geochemical data

BóDI MÁTYÁs: A jelenlét nélküli jelen(lét) - a hazai pártszervezetek fejlettségének területi különbségei / Spatial inequalities in the institualization of Hungarian political parties

Kohut ErzséBET-BenedeK ANETT-HadnAgy IstvÁN: Nagydobrony és a Nagydobronyi Vadvédelmi Rezervátum (Kárpátalja) földrajzinév-tárának elkészítése és ábrázolása történeti térképek alapján / Geoinformatic analysis and representation of the geographical names of Velyka Dobron and the Wildlife Reserve of Velyka Dobron (Transcarpathia) based on historical maps

Krónika / Chronicle

Marczell György emlékezete (1871-1943) - HÁGEN ANDRÁs

\section{Irodalom / Review}

Gábris Gyula (szerk.): 150 éves Magyarország első földrajz tanszéke - HoRVÁTH GERGELY ................ Erdősi Ferenc: A globalizálódott tengerhajózás és a világkereskedelem - KUCSERA EMIL

\section{TÁMOGATÓINK}

\section{ח}

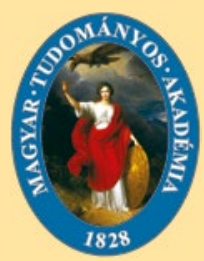

Kiadja a MAGYAR FÖLDRAJZI TÁRSASÁG

A Nemzeti Kulturális Alap és a Magyar Tudományos Akadémia támogatásával

A kiadásért felel: Dávid Lóránt Dénes

Tördelés és nyomdai előkészítés: Bonex Press Kft.

Borítóterv: Liszi János

Nyomdai kivitelezés: Heiling Media Kiadó Kft.

Telefon: (06-1) 231-4040

Készült 300 példányban

HU ISSN 0015-5411 